\title{
UNA PERSPECTIVA PROSOPOGRÀFICA DELS OFICIS MUSICALS DE LA CATEDRAL DE VALÈNCIA EN TEMPS DE GUILLEM DE PODIO, 1480-1505
}

\author{
A PROSOPOGRAPHICAL PERSPECTIVE OF THE MUSICAL TRADES OF THE \\ CATHEDRAL OF VALENCIA IN THE TIME OF GUILLEM DE PODIO, \\ 1480-1505
}

\section{UNA PERSPECTIVA PROSOPOGRÁFICA DE LOS OFICIOS MUSICALES DE LA CATEDRAL DE VALENCIA EN TIEMPOS DE GUILLEM DE PODIO, 1480-1505}

\author{
Francesc Villanueva Serrano \\ Universitat Politècnica de València \\ fvilanue@hotmail.com
}

ORCID iD: https://orcid.org/0000-0002-4680-1546

\begin{abstract}
Resum
L'activitat musical anterior al segle XVI a la catedral de València és molt poc coneguda. El present estudi tracta d'avançar en el coneixement de la qüestió dirigint el focus d'atenció cap als col·lectius de persones que exerciren els diferents oficis catedralicis amb responsabilitat en l'organització i la pràctica de la música en aquest temple en el període 1480-1505, que emmarca el magisteri del tractadista Guillem de Podio en les escoles de cant. La perspectiva que s'ofereix és aportada per la prosopografia, a partir de dades procedents tant de la mateixa institució com d'altres semblants, així com de fonts de característiques diferents com ara les notarials, les diocesanes i les conservades en arxius civils i reials. D'altra banda, el treball també ha permés presentar suficients evidències per poder descartar la hipòtesi d'identificació, fins ara considerada, entre el compositor Juan Rodríguez de Sanabria i el cantor d'Isabel la Catòlica Juan Rodríguez de la Torre. En apèndix s'inclou un catàleg prosopogràfic de tots els personatges estudiats.

\section{Paraules clau}

Catedral de València, Guillem de Podio, Juan Rodríguez de Sanabria, prosopografia, cabiscol, sotscabiscol, mestre de les escoles del cant, cantors, diputats, organistes, inventaris, instruments, llibres.
\end{abstract}

\begin{abstract}
The musical activity in the cathedral of Valencia before the XVIth century is quite unknown. This study seeks to advance the knowledge of this subject focusing on the groups of people carrying out the different trades with responsibility in the organization and the musical practice between 1480-1505. This period comprises treatise writer Guillem de Podio's chant schools mastery in the above mentioned cathedral. The perspective offered here is provided by the prosopography, using data from this institution, other cathedrals and documental sources with different features like notarial, diocesan and those preserved in civil and royal archives. On the other hand, this work has also allowed enough evidence to be presented to dismiss the current identification hypothesis between the composer Juan Rodríguez de Sanabria and the singer of Isabella I of Castile, Juan Rodríguez de la Torre. A prosopographical catalogue of all of the studied individuals is included in an appendix.
\end{abstract}

Key words

Cathedral of Valencia, Guillem de Podio, Juan Rodríguez de Sanabria, prosopography, precentor, succentor, master of the chant schools, singers, boy singers, organists, inventories, instruments, books. 


\begin{abstract}
Resumen
La actividad musical anterior al siglo XVI en la catedral de Valencia es muy poco conocida. El presente estudio trata de avanzar en el conocimiento de la cuestión dirigiendo el foco de atención hacia los colectivos de personas que desempeñaron los diferentes oficios catedralicios con responsabilidad en la organización y la práctica de la música en este templo en el período 1480-1505, que enmarca el magisterio del tratadista Guillem de Podio en las escuelas de canto. La perspectiva que se ofrece es la aportada por la prosopografía, a partir de datos procedentes tanto de la misma institución como de otras similares, así como de fuentes de características diferentes tales como las notariales, las diocesanas y las conservadas en archivos civiles y reales. Por
\end{abstract}

\section{INTRODUCCIÓ}

El mètode prosopogràfic no és una eina de recent aparició en la disciplina històrica, però es ben cert que en els darrers temps està rebent una creixent atenció, especialment per part dels medievalistes, a l'hora de seleccionar estratègies de treball. Aquest recurs metodològic fonamenta l'estudi d'una societat, o d'un colllectiu, en l'anàlisi dels individus que la formen. Entre els camps de la recerca històrica en què l'aproximació prosopogràfica ha mostrat una major capacitat com a procediment hi és l'estudi de l'Església ${ }^{1}$.

En aquest treball es dirigirà el focus d'atenció cap a un grup molt concret dins d'aquest àmbit: el d'aquelles persones eclesiàstiques o seglars que van estar vinculades a la catedral de València amb tasques relacionades amb la regència, organització i pràctica professional de la música en el període 1480-1505, un quart de segle en què queda emmarcat el magisteri de cant en aquesta institució del tractadista Guillem de Podio, que va tenir lloc del 1485 al 1500. Amb aquesta intenció, s'ha confeccionat un catàleg prosopogràfic, o recull de dades biogràtiques procedents de diversos tipus d'arxius i de fonts, així com de bibliografia, de cadascun dels membres del grup estudiat, que serà l'instrument bàsic per a tractar de caracteritzar el perfil dels diferents càrrecs $i$ oficis, el qual s'adjunta en apèndix ${ }^{2}$. No es tracta, ni molt menys, d'una aplicació pionera de la prosopografia en l'estudi de músics de l'època medieval a la península Ibèrica. Segurament, el precedent més clar és el treball de Francisco

1 VONES-LIEBENSTEIN, 14 (Pamplona, 2005): 351-364. Un altra àrea d'aplicació és la cort [CAÑAS GÁLVEZ, 10 (Santa Bárbara, 2008): 31-50].

2 Per raons d'economia en l'escriptura, es remet al lector a l'apèndix prosopogràfic per conèixer les fonts de la informació de cada una de les dades que s'esmenten d'ací en avant corresponents als personatges inclosos. otra parte, el trabajo también ha permitido presentar suficientes evidencias para poder descartar la hipótesis de identificación, hasta ahora considerada, entre el compositor Juan Rodríguez de Sanabria y el cantor de Isabel la Católica Juan Rodríguez de la Torre. En apéndice se incluye un catálogo prosopográfico de todos los personajes estudiados.

\section{Palabras clave}

Catedral de Valencia, Guillem de Podio, Juan Rodríguez de Sanabria, prosopografía, chantre, sochantre, maestro de las escuelas del canto, cantores, infantes cantores, organistas, inventarios, instrumentos, libros.

de Paula Cañas Gálvez sobre els músics a la cort d'Enric IV de Castella (1454-1474) ${ }^{3}$.

La catedral de València del segle XV i primers anys del segle XVI és molt poc coneguda pel que fa a l'activitat musical i els seus protagonistes, una circumstància, malauradament, gens excepcional en l'àmbit de la península Ibèrica ${ }^{4}$. De fet, són bastant minsos, i de temàtica molt concreta, els estudis disponibles que aporten una mica de llum sobre el fet musical en la institució valenciana en un període, paradoxalment, d'especial rellevància des del punt de vista històric i cultural, tant per a la seu com per a la ciutat ${ }^{5}$.

\section{LA CATEDRAL DE VALÈNCIA A LES ACABALLES DEL SEGLE XV}

La catedral de les darreres dècades del segle es trobava immersa en una etapa de gran efervescència artística i cultural, afavorida per la puixança econòmica política i demogràfica d'una ciutat que travessava els moments més àlgids d'allò que comunament s'ha anomenat el Segle d'Or valencià. De fet, aleshores s'assistia a la fase final de les obres d'ampliació de les naus (1458-1485), dirigides per Pere Compte, que definitivament unien el temple amb la torre

3 CAÑAS GÁLVEZ, 29:1 (Madrid, 2006): 217-313. Així mateix, recentment s'ha fet servir aquest recurs de manera complementària en un estudi sobre els músics a la cort de Joan II d'Aragó (1458-1479) [VILLANUEVA SERRANO (2016)].

4 Dins d'aquest desèrtic panorama cal destacar especialment el treball dedicat a la catedral de Sevilla RUIZ JIMÉNEZ, 29 (Cambridge, 2010): 189-239.

5 En la bibliografia disponible destaquem: SANCHIS Y SIVERA (1909): 223-232; 86 (Madrid, abril-juny, 1925): 467-473. VILLALMANZO, 12 (València, octubre-desembre 1984): 14-21, 2428. SIERRA (1985). CLIMENT BARBER, X:1 (Madrid, 1987): $163-$ 169. ANDRÉS FERRANDIS (2001). VILLANUEVA SERRANO, 65 (Barcelona, 2010): 3-23; 34:1 (Madrid, 2011): 37-58; 30 (Saragossa, 2014a); 43 (Laaber, 2014b): 7-31. 
campanar del Miquelet i amb la sala capitular, en aquest darrer cas a través d'un passadís (1496). Així mateix, s'estaven encara pintant els dotze àngels músics que decoren la volta de la capella major (1472-1481), considerats com la primera manifestació rellevant en l'estil renaixentista pictòric a la península Ibèrica, de la mà dels mestres italians Paolo de San Leocadio i Francesco Pagano, alhora que es reconstruïa el retaule d'argent a la mateixa capella, que pràcticament havia desaparegut en un incendi l'any $1469^{6}$. La notable activitat literària a la ciutat era dinamitzada per un domer i beneficiat de la catedral, anomenat Bernat Fenollar ${ }^{7}$, el qual organitzava i participava en certàmens i debats poètics, tant de caràcter religiós com profà. Precisament un d'aquests certàmens va originar el primer llibre imprès de literatura a la península: Les trobes en lahors de la Verge Maria (València: Lambert Palmart, 1474) ${ }^{8}$. Al mateix temps, el bisbe auxiliar Jaume Pérez de València feia rellevants aportacions als estudis bíblics.

A partir del 1429, la diòcesi valentina fou governada per successius membres de la poderosa família Borja, malgrat que des de Roma. Al principi del període d'estudi fixat per a aquest treball, el bisbe i cap de l'església valentina era el cardenal Roderic Borja, futur papa Alexandre VI. Des del seu lloc preeminent a la cort romana, aquest influent personatge va ser el promotor de l'elevació de la seu valenciana al rang de metropolitana, esdeveniment que fa tenir lloc el 9 de juliol de 1492. En ser elegit màxim pontífex només un mes més tard amb el nom d'Alexandre VI, va transferir la mitra arquebisbal al seu fill Cèsar Borja, a la qual aquest va renunciar el 1498. Posteriorment, el papa valencià va concedir l'arquebisbat, successivament

6 Sobre l'art a la ciutat en aquest temps pot consultar-se, entre altres publicacions, AGUILERA CERNI (1986-1987), vol 2, 3. Sobre els àngels músics, vegeu, entre altres: MIGLIO, OLIVA i PÉREZ GARCÍA (2011).

7 Un mossèn Bernat Fenollar "natural de la ciutat de València e benefficiat en la seu de la dita ciutat" fou inscrit com a "capellà e mestre de la capella" del rei Ferran el Catòlic a Barcelona el 23 de setembre de 1479 [E-Bac, Reial Patrimoni, Mestre Racional, Sèries Generals A), Escrivania major de ració del rei, Llibres registres dels empleats que ingresaven en el càrrecs de palau i assignacions assenyalades, carta de ració, vol. 939bis, f. 173v]. Actualment, no es pot descartar que es tractara d'aquest personatge, malgrat que sembla que l'escriptor era natural de Penàguila [HINOJOSA (2002): vol. 2, 196-197]. Una altra possibilitat és que el receptor del nomenament reial fóra un personatge homònim, com sembla que ho era un beneficiat de la parròquia de Sant Llorenç [E-VAcp, not. Guillem Ramon Tovia, vol. 26408, 8 de juny de 1505]. De qualsevol manera, segurament es va tractar en aquest cas d'un nomenament honorífic (capellà d'honor), atès que no es disposa de cap dada addicional que suggerisca la condició de músic ni de cap pagament en aquest càrrec.

8 Sobre la literatura a València en aquesta època pot consultar-se especialment RIQUER (1980): vol. 2. als seus nebots Joan Borja (1499-1500) i Pere Lluís Borja $(1500-1511)^{9}$.

En aquest temps, la nombrosa comunitat catedralícia valenciana estava encapçalada pel bisbe o, posteriorment, l'arquebisbe -sempre absent-, un bisbe auxiliar amb el títol de Cristòpolis, set dignitats -degà, cabiscol, sagristà, ardiaca major i ardiaques de Morvedre, de Xàtiva i d'Alzira- $\mathrm{i}$ vint-i-cinc canonges -algunes canongies pertanyien a les dignitats, una altra al rei, i alguns dels canonges tenien també el títol de paborde-, tots els quals constituien el capítol o orgue col-legiat rector de la seu. Completaven el clero de la catedral més de dos-cents beneficiats, rendistes de béns normalment llegats per particulars, a més d'altres eclesiàstics i seglars que exercien diversos oficis en la litúrgia o en la conservació del temple ${ }^{10}$. Dins d'aquest grup, es trobaven els anomenats oficis de l'altar major, específicament dedicats al manteniment del culte general de la seu: quatre domers, dos diaques, dos sotsdiaques, dos sotscabiscols, el sotssagristà, el vicari de Sant Pere, els capellans d'alba, i el racional ${ }^{11}$. Entre els càrrecs $\mathrm{i}$ oficis associats amb la música es distingien aquells relacionats amb el cant pla comú -cabiscol i sotscabiscols-, aquells que es dedicaven a l'ensenyament i al cant polifònic -el mestre de cant $i$ els cantors- $i$ aquells que sonaven els orgues -organistes-. Amb el nom de diputats es coneixia a València als infants que, entre altres funcions auxiliars, intervenien amb el seu cant en els oficis ${ }^{12}$.

\section{CABISCOLS I SOTSCABISCOLS: LITÚRGIA I CANT PLA}

Una de les set dignitats catedralícies valencianes era el praecentor o cabiscol, antic caput scholae, anomenat usualment chantre en les catedrals castellanes. Feia ja molt de temps que no exercia directament les seues funcions en matèria de litúrgia i cant pla sinó que, des d'abans del 1334 , la seu comptava amb uns ajudants que s'ocupaven directament d'aquestes funcions, anomenats succentores o

9 CÁRCEL ORTÍ (2001): 151-191, 960.

10 Sobre els membres de la catedral de València es pot consultar SANCHIS Y SIVERA (1909): 13-55. PONS ALÓS i CÁRCEL ORTÍ, 35:2 (Barcelona, 2005): 907-950.

11 "Clerici de altari maiori, qui sunt quatuor Hebdomadarii, Vicarius Sancti Petri, Capellanus de alva, duo succentores, duo diaconi, duo subdiaconi, subsacrista et Rationalis praedictus, habeant de anniversariis et processionibus ante dictis, ut superium est distinctum". Tots aquests oficis ja estaven perfectament establits abans del 3 d'octubre de 1420 [PÉREZ DE MIEDES (1546): 106r].

12 Més detalls sobre l'organització del personal músic de la catedral poden trobar-se dins VILLANUEVA SERRANO, 64 (Barcelona, 2009): 80-99. 
sotscabiscols, sochantres a Castella. A diferència d'altres catedrals de la Corona, com ara la de Barcelona o la de Girona, a la seu valenciana el càrrec de sotscabiscol no estava adscrit a un membre capitular sinó a un simple beneficiat i, a més, no hi havia un sinó dos ${ }^{13}$. Malgrat que no he pogut localitzar documentació molt detallada sobre les funcions concretes d'aquests oficis, hi ha suficient per a considerar que, com era habitual a les catedrals hispàniques, eren els responsables de l'organització litúrgica del cant pla comú del clero catedralici, tant des del punt de vista de la selecció com de la interpretació de la música, així com del règim disciplinari en el cor $^{14}$.

En el període d'estudi van ocupar la dignitat de cabiscol, successivament, sis membres de les famílies valencianes més poderoses de l'època: els Vich -Guillem de Vich (1461a-1485) i Guillem Ramón de Vich (1485), fill del mestre racional de València-; els Borja -Martí Enyego (1485-1489), oncle del papa Alexandre VI, i Joan de Borja (1489-1492p)-; els Vera, família alzirenca molt propera al papa -Joan de Vera (1494-1500), preceptor de Cèsar Borja, i Sanç de Vera (1500-1504p)-. Per tant, la cabiscolia era constantment ocupada per components de la capa social més elitista del regne. A més, sembla que hi havia tendència a ser mantinguda en poder de les mateixes famí-

13 "Succentoribus vero dicte sedis, qui sunt duo [...]". La cita procedeix d'una ordinació sobre les distribucions catedralícies datada el 7 d'abril de 1334 [PÉREZ DE MIEDES (1546): 1v].

14 Se sap que el 1242, quatre anys només després de la conquesta de la ciutat, el cabiscol de la seu valenciana recent consagrada era encara l'encarregat d'assignar els cants i mantenir la disciplina en el cor: “(...) iniungat etiam dictus Praecentor in die praecedenti, qui responsoria, lectiones, antiphonas, officium, et invitatorium: et alia ad divinum officium pertinentia cantare debeant: ut cum provisione, quod iniunctum fuerit, quilibet laudabiliter exequantur. Et qui defectum fecerit in praemissis, duobus denariis portionis illius diei, absque remedio, puniatur. Et si Praecentor, per se, vel per alium dictam assignationem non curaverit adimplere, portione illius diei noverit se privatum."; "Item adiicimus quod nullus in choro alte loquatur dum divinum officium celebratur: sed si quid, causa correctionis, Precentor, ut divinum officium melius fiat, duxerit ordinandum, submissa voce dicat: ut Domus Dei domus orationis sit, et non domus litigii vel clamori." [PÉREZ DE MIEDES (1546): LXXXIIIr]. Significativament, en una addició del bisbe Hug (Hug de Fenollet, 1348-1356, o Hug de Llupià, 1398-1427) es traspassava directament al sotscabiscol el control disciplinari d'assistència al cor: "HUGO, Statuimus etiam de praesentis Capituli consensu, quod nullus canonicus vel clericus ad matutinos infra chorum intret: nisi venerit anteque sit finitus primus psalmus matutinorum maiorum: nec ad missam, nisi venerit ante finitam epistolam (...). Immo per succentorem, vel alios chorum regentes a choro paenitus expellatur." [PÉREZ DE MIEDES (1546): LXXXIIIr]. Així mateix, en l'edició del 1546 consta una nota al marge de la primera disposició adés transcrita que informa que la funció d'assignar el cants l'havien assumit els sotcabiscols: "Succentor tenetur iniungere die praecedenti quae die subsequenti sunt dicenda in choro" [PÉREZ DE MIEDES (1546): LXXXIIIr]. lies, de manera que s'entreveu un cert caràcter patrimonial d'aquesta dignitat catedralícia que es pot explicar per les altes rendes de què gaudia ${ }^{15}$. Però no només el cognom insigne adornava als seus titulars, sinó que d'almenys alguns se sap fefaentment que tenien estudis universitaris. Guillem de Vich i Joan de Vera eren doctors en decrets i Martí Enyego era mestre en sacra teologia. En tres dels sis casos, s'observa un nítid cursus honorum en la seua trajectòria que començava per la possessió d'un canonicat a la seu, passava per ocupar la dignitat de la cabiscolia i acabava pel salt a la Roma d'Alexandre VI, des d'on dos d'ells arribaren fins i tot a cardenals (Guillem Ramon de Vich i Joan de Vera) i el tercer a arquebisbe de Pàdua (Joan de Borja). La resta va romandre a València, la qual cosa no va impedir a Martí Enyego arribar a ser un dels dos inquisidors dels regne. La dignitat de cabiscol era de la màxima confiança del bisbe, i després arquebisbe, de València en les qüestions administratives, per la qual cosa eren sovint nomenats vicaris generals de la diòcesi. A més de cabiscol i vicari general, Joan de Vera fou protonotari apostòlic, de manera que esdevingué un personatge totpoderós en l'Església valenciana en el darrer lustre de segle. Aquesta circumstància, i la seua condició de càrrec de màxima jerarquia en matèria de música a la seu, podria explicar la decisió de Guillem de Podio de dedicar-li el seu tractat Enchiridion de principiis musice discipline. A Roma, Joan de Vera va continuar la seua vertiginosa trajectòria. De fet, no només va rebre el cardenalat de Santa Balbina i l'arquebisbat de Salern, sinó que va arribar a ser camarlenc del Col-legi Cardenalici i, fins i tot, candidat al papat en morir Alexandre VI.

Ha sigut possible determinar la identitat de quatre dels sotscabiscols del període estudiat. Una de les dues places va ser ocupada, successivament, pels preveres Francesc Robiols (1459a-1484), Francesc Roig (14841486) i Joan Roger (1486-1516). De l'altra se sap que fou exercida per Joan Balaguer en el període 1491-1522 com a mínim. Probablement tots ells, atenent al cognom, eren naturals del regne valencià i no pertanyien a l'estament nobiliari. No obstant això, tampoc sembla que formaren part del clero més baix. Almenys, la documentació testamentària de Robiols permet saber que gaudia d'una folgada posició econòmica com a membre d'una família acomodada de mercaders i notaris. De fet, en morir tenia tres servidors a sa casa, el manteniment dels quals feien possible les rendes de la rectoria de Dosaigües i quatre

15 El 1456, la cabiscolia valia 237 lliures mentre que una simple canongia valia 33 lliures [CIPRÉS DE POBAR (1641): 24-26]. 
beneficis a la ciutat de València ${ }^{16}$. Roger també disposava d'una criada, encara que sembla que era de família més modesta, puix tenia un nebot artesà -capser- i en el seu testament únicament destaca la possessió d'una casa. Tres dels quatre sotscabiscols van tenir trajectòries llargues en l'ofici, de més de tres dècades, la qual cosa sembla indicar que es tractava de preveres locals que no circulaven per diverses institucions, segurament amb sòlids coneixements en litúrgia però més limitats en els musicals, potser restringits al cant pla. De fet, els llibres de Robiols que són esmentats explícitament en el seu testament són fonamentalment litúrgics i de temàtica religiosa, al temps que no és citat cap exemplar de música especulativa ni de pràctica polifònica ${ }^{17}$. Així mateix, els coneixements $\mathrm{i}$ l'autoritat en litúrgia degueren valdre a Joan Roger per a ser elegit pel capítol el 1503 per a corregir el breviari segons el costum valencià que havia sigut autoritzat per a imprimir al llibrer Gaspar Trincher i a l'impressor alemany Cristòfol Koffman ${ }^{18}$.

\section{MESTRES DE LES ESCOLES DEL CANT I CANTORS: ENSENYAMENT I CANT POLIFÒNIC}

La primera notícia de què fins ara es disposa que és testimoni fefaent de l'existència a la seu de València d'escoles del cant i del càrrec de mestre d'aquestes es remunta al $1351^{19}$. Durant la major part del segle XV, la titularitat

16 Sobre l'estudi de diversos centenars de beneficiats a la València de 1448, Rosa Munsuri conclou que només el $2 \%$ d'aquests posseïen cinc beneficis, mentre que cap en tenia sis o més [MUNSURI ROSADO (2010): 188].

17 Els llibres litúrgics són un missal mixt, un altre missal, un diürnal i dos breviaris. Els religiosos són: "Manipulus curatorum" (manual de rectors de parròquia, Guido de Monte Rochen, segle XIV); "Vita Christi de Bonaventura" (Meditationes de Vita Christi, pseudo-Bonaventura, segle XIV); "Excitatorium mentis in Deum" (Excitatorium mentis ad Deum, Bernat Oliver, segle XIV); "Bertholina" (possiblement Summa de casibus conscientiae, manual pràctic per a confessions, de Bartholomeus de San Concordio, segle XIV); "Anthonina" (Summa theologica moralis o Summa confesionalis de Sant Antonino de Siena, segle XV). A més, posseïa un "Catholicon" (Summa grammaticalis, diccionari de llatí, de Johannes Balbus (1286)) i llibres de poesia sense detallar.

18 Es conserva un Breviarium secundum consuetudinem metropolitane ecclesie Valentine [E-VAc, A-218 (2-A)] que es va acabar d'imprimir el 15 de desembre de 1503 a Saragossa per Jorge Coci i Lleonart Hutz -impressor que des del 1488 al 1495 havia treballat a València, on tornà el 1505 [HINOJOSA (2002): vol 2, 456]. Es desconeix si l'autorització va tenir relació amb aquest imprès.

19 El 20 d'abril de 1351, el bisbe Hug de Fenollet va nomenar el prevere Jaume Vidal magister de les "majores scolas cantus" de la catedral. La transcripció del nomenament de Vidal pot trobar-se en RUIZ DE LIHORY (1903): XXIII, nota 2. No obstant això, sí que consta haver-hi una "escola de la ciutat" (schola civitatis) des de la mateixa con- de l'ofici de mestre de les escoles del cant catedralícies era adjudicada anualment a un canonge diferent al cabiscol a les acaballes de l'abril, en els anomenats capítols pasquals; però al mateix temps, com era habitual en la majoria dels oficis canonicals, es nomenava un beneficiat substitut, que era un músic professional que exercia de fet les funcions d'aquell i gaudia comunament del títol de mestre ${ }^{20}$. La designació, tant per al titular com per al substitut, tenia vigència només durant el següent exercici administratiu, és a dir, des de l'1 de maig de l'any en curs fins al 30 d'abril de l'any següent. Tot i la manca de documents en l'àmbit d'estudi valencià, cal suposar que les responsabilitats del mestre de les escoles del cant de la seu valenciana d'aquesta època no es restringien a l'ensenyament sinó que s'estenien a la conducció i interpretació de la música polifònica durant els oficis catedralicis ${ }^{21}$. Simptomàticament, al començament del 1506 es pot constatar per primera vegada a la seu valenciana l'ús de la denominació de mestre de capella aplicada al mateix músic que fins aleshores s'anomenava mestre de cant o mestre de les escoles del cant catedralícies. Aquell títol, que ja s'usava a les capelles reials i nobiliàries, es generalitzarà en poc de temps a la seu valenciana ${ }^{22}$. La doble denominació en l'època de transició terminològica és prova de l'equivalència dels càrrecs $i$, per tant, de les funcions habituals que, en el cas del mestre de capella són molt més conegudes per a les catedrals del segle XVI i posteriors.

questa (1240), que va ser assignada al cabiscol [PÉREZ DE MIEDES (1546): f. XLVIIr].

20 Tant el canonge com el substitut es nomenaven "ad regendum scolas cantus".

$21 \mathrm{Si}$ es consideren alguns documents coneguts sobre les obligacions dels qui exercien el magisteri a les catedrals peninsulars de la segona meitat del segle XV -"cantor" a Lleó (1458 i 1464), "maestro de canto" a Saragossa (1472), "mestre de les escoles del cant" a Barcelona (1483) o "maestro cantor" a Àvila (1487)-, sembla que era habitual que, a banda de les obligacions en la formació dels infants cantors -i també d'alguns dels clergues residents- els mestres participaren activament en la interpretació del cant pla i polifònic i, fins i tot, s'encarregaren de donar el to al cor eclesiàstic [ÁLVAREZ PÉREZ, 14 (Barcelona, 1959): 40-41. MOLL, 22 (Barcelona, 1967): 91-92. CALAHORRA MARTÍNEZ (1978): vol. 2, 17. GREGORI I CIFRÉ, III (Barcelona, 1983): 33-34].

22 E-VAc, Almoina, Procura Major, núm. 5688, any 1506, f. $48 \mathrm{v}$. Les primeres aparicions constatades de la denominació maestro de capilla en altres catedrals peninsulars daten d'aquesta època o són un poc posteriors: a la catedral de Sevilla no després del 1503, a la d'Oviedo el 1517, a la de Burgos el 1521 i a la de Palència el 1524 [STEVENSON (1985): 19. RUBIO (1983): 17]. 


\begin{tabular}{ccc} 
Data & Canonge rector & Beneficiat substitut \\
\hline 26-04-1486 & Macià Mercader & Guillem de Podio \\
28-04-1487 & Pere Pau Rossell & Guillem de Podio \\
29-04-1488 & Pere Pau Rossell & Guillem de Podio \\
27-04-1489 & Macià Mercader & Guillem de Podio \\
26-04-1490 & Pere Pau Rossell & Guillem de Podio \\
07-04-1491 & Pere Pau Rossell & Guillem de Podio \\
27-04-1492 & Pere Pau Rossell & Guillem de Podio \\
29-04-1493 & Pere Pau Rossell & Guillem de Podio \\
22-04-1494 & Pere Pau Rossell & Andrés de Soria \\
30-04-1495 & Jaume Conill & Guillem de Podio \\
$29-04-1496$ & Martí Enyego & - \\
$28-04-1497$ & Pere Pau Rossell & Guillem de Podio \\
$27-04-1498$ & Pere Pau Rossell & Guillem de Podio \\
$29-04-1499$ & Pere Pau Rossell & Guillem de Podio \\
$26-04-1501$ & Pere Pau Rossell & Honorat Strimundi \\
$26-04-1503$ & Pere Pau Rossell & Honorat Strimundi \\
$26-04-1504$ & Miquel Dassió & Honorat Strimundi \\
$26-04-1505$ & Pere Dies & \\
\hline & & \\
\hline
\end{tabular}

Taula 1. Canonge rector de les escoles del cant i beneficiat substitut en els capítols pasquals localitzats del període 1480-1505.

Sembla que l'elecció de canonges rectors de les escoles del cant en el període d'estudi es duia a terme sense respectar un ordre predefinit, puix en la major part dels anys de què es disposa de dades, aquesta responsabilitat va recaure sobre una mateixa persona: Pere Pau Rossell. Aquest capitular procedia d'una família valenciana afavorida pel rei Joan II arran del nomenament de son pare, el notari Pau Rossell, com a escrivà de ració del sobirà. Pere Pau va acumular progressivament prebendes eclesiàstiques -fou capellà reial, posseïdor d'almenys tres beneficis i una rectoria, així com canonge de Xàtiva-abans d'aconseguir la canongia a la seu valenciana el 1486. Així mateix, era doctor en decrets, com també ho eren altres dos dels canonges que regiren les escoles del cant en aquests anys -Macià Mercader i el ja esmentat Martí Enyego-, mentre que Jaume Conill era mestre en arts i en sacra teologia. D'entre tots ells, sembla que qui tenia més inquietuds humanístiques fou Mercader, un personatge d'origen noble i d'una àmplia cultura. És conegut que fou autor d'una obra sobre falconeria i que quan va morir comptava amb una rica biblioteca de més de 200 llibres, majoritàriament de religió i d'humanitats ${ }^{23}$. Tenia coneixements musicals, puix al seu inventari post-mortem consta un llibre de cant així com un "cínbol" (possiblement un cèmbal) i un monacord, malgrat que el darrer era prestat ${ }^{24}$. Aquesta competència en la matèria segurament explica el fet que fóra triat pel capítol per a signar tots tres contractes de construcció o remodelació d'orgues de la seu valenciana coneguts durant el segle XV.

Durant els tres lustres centrals del període d'estudi, el càrrec de mestre de les escoles del cant, substitut del canonge titular, va correspondre al tractadista Guillem Molins àlies de Podio. Aquest rellevant músic va arribar a la ciutat de València a les acaballes del 1479 amb una edat bastant avançada, al voltant dels 60 anys, després d'haver sigut mestre de cant de la seu de Barcelona (1446-1458) així com, posteriorment, cantor de la capella reial de Joan II (14581479), al llarg de tot el seu regnat, i mestre de la capella de la reina Joana (1461a-1468), fins a la mort d'aquesta. Des del 1471 fins el 1479, a més, va alternar les estades a la cort amb períodes de residència com a prevere de capítol i lloctinent de cabiscol major de la catedral de Girona. A la seu valenciana ja gaudia, amb anterioritat a l'arribada a la ciutat, d'un benefici de patronat reial a la capella de Sant Jaume que, aparentment, va ser l'únic lligam amb la institució fins que el 1485 el capítol va concedir-li el càrrec de mestre de les escoles de cant catedralícies. Anualment fou renovat el seu nomenament en aquest prestigiós ofici, potser afavorit per la presència del seu antic company de la capella reial Pere Pau Rossell com a canonge titular, fins la mort del músic el dia de Tots Sants del 1500, només amb l'excepció dels anys 1494 i $1496^{25}$. D'aquest període valencià daten les dues obres fonamentals conservades de Guillem de Podio. D'una banda, el 1495 s'imprimia a València pels alemanys Peter Hagenbach i Leonhardt Hutz l'ambiciós tractat Ars musicorum o Commentariorum musices (1495), un compendi sobre música especulativa i pràctica -dividida en les tres disciplines tradicionals de cant pla, cant d'orgue i contrapunt-. Amb posterioritat, Guillem de Podio va escriure Enchiridion de

23 FERRER GIMENO, 4 (1987-1988): 441-469. La distribució temàtica percentual segons María Rosario Ferrer és: Religió $(43,06 \%)$, Humanitats $(41,08 \%)$, Ciències $(5,97 \%)$, Dret $(4,45 \%)$, Altres $(5,44 \%)$.

24 "Item, un libre en paper ab cubertes de fust, cubertes de cuyro vermell, de cant ab moltes obres e officis de cant." [FERRER GIMENO, 4 (1987-1988): 459]; "Item, un tabaquet de verga blanca ple de cordes, símbol e menacora.” [FERRER GIMENO, 4 (1987-1988): 460]; “Item, altra caxa de alber de Barcelona, dins la qual hi havia un menacort e alguns libres, la qual caxa e coses trobades en aquella se diu són de Albert."; "Item, un cínbol ab sa caxa de fust." [FERRER GIMENO, 4 (1987-1988): 465].

25 Poden trobar-se els detalls biogràfics actualment coneguts d'aquest personatge en VILLANUEVA SERRANO (2015): vol I, 49168 . 
principiis musice discipline contra negantes illa et destruentes, un escrit de caràcter eminentment especulatiu i singular en la intencionalitat -rebatre allò que l'autor considerava errors en la teoria del seu temps-, que únicament es conserva en el ms. A.71 del Museo internazionale e biblioteca della musica de Bolonya ${ }^{26}$.

En contrast amb aquest enlluernador historial, sembla que la resta de mestres del període d'estudi -Pasqual Martí (1451-1461a; 1471(?)-1485), Andrés de Soria (1494-1495) i Honorat Strimundi (1501-1504p)- van ser músics vinculats exclusivament a la catedral de València o, almenys, residents en aquest temple durant dècades abans de morir a la mateixa ciutat. A més, tots tres van ser cantors al llarg de bastants anys abans d'assumir la responsabilitat del magisteri, la qual cosa suggereix que els seus nomenaments es produïren més bé per promoció interna dins de la institució en raó de l'antiguitat i confiança del capítol que no per una prestigiosa carrera exterior, com fou el cas paradigmàtic de Podio. Martí ja era cantor el 1447 i per dues vegades va cedir el càrrec de mestre -primerament a Lluís Domínguez àlies Adzuara (1461a) i, més tard, a Guillem de Podio (1485)- però en ambdues ocasions va romandre com a cantor a la seu, malgrat que, almenys en el segon cas, possiblement actuara com a una mena de segon mestre. Soria, possiblement d'origen aragonès, era cantor el 1471 però el 1483 sembla que es va desvincular dels oficis musicals, al temps que consta que va passar a exercir diversos càrrecs administratius encomanats pel capítol de la catedral. Possiblement, la confiança de què gaudia entre els canonges va afavorir-lo en l'elecció capitular per a substituir breument Guillem de Podio en el magisteri del cant l'any 1496. La preeminència de Soria en la vessant administrativa explicaria també que l'any següent s'encarregara del cobrament de l'actuació d'un grup de vuit cantors, segurament catedralicis, que assistiren a les exèquies de Joan de Borja, duc de Gandia. Per últim, Honorat Strimundi, possiblement originari dels Estats Pontificis, va ser cantor de la seu des del 1482 fins, segurament, el seu nomenament com a mestre el 1501, a la mort de Guillem de Podio, un càrrec que va retenir fins el seu traspàs el 1504. Afortunadament, he pogut localitzar els inventaris post mortem de tots tres músics, els quals ajuden a conèixer els seus interessos i la seua, aparentment, gens trivial formació intel·lectual a tra-

26 La bibliografía sobre aquestes obres es molt àmplia i no la citarem per no ser l'assumpte central d'aquest treball. El lector interessat pot consultar una breu introducció actualitzada a la producció de Guillem de Podio, incloent-ne referències bibliogràfiques, en VILLANUEVA SERRANO (2015): vol I, 380-387. Sobre l'Enchiridion pot trobar-se molta més informació en VILLANUEVA SERRANO (2015): vol I, 431-462. vés de les respectives biblioteques. Martí comptava amb 15 llibres -especialment de teologia, litúrgia i filosofia-, entre els quals es trobava "Guidonis de arti musicali" -segurament Micrologus de disciplina artis musicae de Guido d'Arezzo-, a més de "molts altres llibres axí de pergamí com de paper de poqua valor" 27 . En l'inventari de Soria es relacionen cinc llibres litúrgics, un de medicina i "uns qüerns de libres de quant squadernats" que, desafortunadament, no són descrits en detall ${ }^{28}$. La biblioteca de Strimundi era, amb diferència, la més copiosa de les tres, puix disposava de 51 llibres, fonamentalment d'impremta i en llatí, sobre litúrgia, moral i religió però també sobre filosofia o sobre medicina. Malauradament, tampoc coneixem els llibres de cant que, amb tota seguretat, Strimundi posseïa, els quals va llegar explícitament a la seu per via testamentària ${ }^{29}$. Paradoxalment, aquest darrer músic sembla que fou el menys agraciat dels tres en l'aspecte econòmic puix, ni tan sols, consta la possessió de la seua vivenda, mentre que Soria en tenia tres i Martí fins a vuit, a més de nou fanecades de terra.

Des de mitjan segle XV, en els llibres de comptes del procurador major de l'Almoina de la catedral consten els lliuraments de salaris, en concepte de senyals, a músics específicament contractats en l'ofici de xantres o cantors. Els senyals -pensions equivalents a 7,5 lliures anuals per unitat- foren originàriament instituïts, fonamentalment per particulars, com a obres de caritat destinades a ajudar els necessitats. Eren gestionats per l'administració catedralícia de l'Almoina, la qual lliurava diàriament als pobres receptors la part alíquota corresponent a través de l'anomenat pagador dels senyals. Però, fins a mitjan segle XVI, el capítol també va usar una part d'aquells que tenia a lliure disposició per a satisfer salaris als cantors, els quals es fixaven en el moment de l'ingrés en termes d'un nombre de senyals. Quan no hi havia disponibles senyals ordinaris en el moment que la seu desitjava incorporar nous cantors, o quan era convenient per qualsevol altre motiu, el capítol ordenava el pagament de senyals al procurador major de l'Almoina, que en aquest cas no les lliurava diàriament als músics sinó en quantitats discretes, una o diverses vegades a l'any. Fins i tot, el capítol

27 Pot consultar-se el darrer testament i l'inventari de béns de Pasqual Martí, a excepció dels objectes domèstics, aliments i indumentària dins VILLANUEVA SERRANO (2015): vol II, p. 416-420.

28 Pot consultar-se un codicil i l'inventari de béns d'Andrés de Soria, a excepció dels objectes domèstics, aliments i indumentària dins VILLANUEVA SERRANO (2015): vol II, p. 445-448.

29 Ítem, do e leix tots los meus libres de cant a la seu de València" [E-VAcp, not. Felip d'Abella, vol. 607, s/f, 27 d'agost de 1504]. Pot consultar-se el darrer testament i l'inventari de béns d'Honorat Strimundi, a excepció dels objectes domèstics, aliments i indumentària dins VILLANUEVA SERRANO (2015): vol II, p. 433-435. 
podia prescriure el repartiment dels senyals d'un mateix cantor entre ambdós pagadors de l'Almoina. Per tant, el registre complet dels cantors de la catedral en un moment concret només es podria conèixer a partir de les dades procedents conjuntament dels llibres de comptes del procurador major i del pagador dels senyals. Malgrat que es conserven els llibres del primer d'aquests, i molts dels rebuts notarials dels pagaments allí continguts, l'aparent pèrdua dels llibres del pagador dels senyals corresponents al segle $\mathrm{XV}^{30}$ ens priva d'esbrinar amb detall i seguretat els cantors de la seu en aquest temps. No obstant això, en la taula 2 es registren els noms dels 26 cantors i mestres del cant de la catedral identificats en el període d'estudi, la qual, pels motius adés esmentats, no pot considerar-se completa sinó una aproximació de mínims.

Des del 1480 fins al 1493 el nombre anual de cantors, incloent el mestre, que transmeten els pagaments del procurador major oscilla entre cinc i vuit. No obstant això, a partir del 1494, i fins la fi del període d'estudi, són molt menys les presències constatades -en diversos anys només dos cantors $i$ en un parell d'anys, fins i tot, tan sols un- la qual cosa suggereix el transvasament de la responsabilitat de l'abonament de la major part dels senyals des del procurador major al pagador, puix en tal cas s'explicaria la pèrdua del rastre dels receptors en la documentació disponible. El nombre més habitual de senyals destinats als cantors en el període fou el de dos, els quals reportaven 15 lliures anuals, una quantitat que s'assemblava a les rendes d'un benefici poc lucratiu de la seu ${ }^{31}$. En alguns casos, el cantor començava el servei amb només un senyal però posteriorment el salari era incrementat a dos i, en unes poques ocasions, fins a tres ${ }^{32}$. L'anormal

30 La sèrie que s'ha pogut localitzar comença en l'any 1511 [E$V A c$, vol. 5614].

31 Els beneficis de la seu de València reportaven de 15 a 30 lliures anuals als titulars [E-VAc, vol. 1554.]

32 Només consta que van arribar a rebre 3 senyals Joan Sanç, Francesc Lagar i Jaume Just. manteniment d'un únic senyal al tenorista Gabriel Soria durant els 45 anys al servei de la seu potser podria explicar-se pel fet que tenia les necessitats bàsiques cobertes en ser frare resident al convent de Sant Domènec de València. De fet, sembla que la seu tenia en compte les circumstàncies personals dels músics, puix també consten concessions d'ajudes individualitzades amb motiu de malalties, del retir o del primer establiment de casa a la ciutat $^{33}$. Una altra possibilitat a l'abast del capítol per a incrementar els ingressos dels cantors era atorgar-los el dret a cobrar els anomenats percaços, que es rebien com a contraprestació d'actes extraordinaris ${ }^{34}$. Només en uns pocs casos s'ha pogut verificar la possessió de beneficis per part de cantors, que pogueren així augmentar els ingressos particulars. Els més afortunats en aquest aspecte eren els músics que havien tingut o tenien alguna vinculació amb patrons poderosos, com ara Guillem de Podio amb el rei Joan II o Guillem Rabós amb l'infant Enric, virrei de València en el període 1496-1505, puix aquests professionals solien ser afavorits en la concessió de beneficis ${ }^{35}$. En una ocasió excepcional, consta que la seu va autoritzar en el moment de l'admissió d'un cantor catedralici, Joan Colomer, la continuació del seu servei com a beneficiat en la parròquia valenciana de Sant Martí. Els cantors de la seu valenciana en aquest temps eren majoritàriament preveres, però una part gens menyspreable, almenys sis, eren frares. Entre ells, destacaven els Predicadors o de l'orde de Sant Domènec, algun dels quals, fins i tot, va encarregar-se d'algun sermó a la seu en festivitat rellevant ${ }^{36}$. En canvi, la presència de laics fou testimonial i reduïda a un únic cantor constatat, anomenat Pedro de Rogés.

33 Ajudes per malalties van rebre Gabriel Soria, Pasqual Martí i Honorat Strimundi; Andreu Vicent va cobrar una subvenció pel retir; Pedro Pérez va rebre una ajuda per establir-se a València.

34 Consta que fou atorgat aquest dret, almenys, a Lope de Sagredo, Guillem Rabós, Francesc Lagar, Jaume Just, Joan Colomer i Ramon Damià. Per al període 1526-1541 pot consultar-se més informació sobre el règim retributiu dels cantors dins VILLANUEVA SERRANO, 64 (Barcelona, 2009): 88-89.

35 També consta que disposaven, almenys, d'un benefici en algun moment Pasqual Martí, Andrés de Soria i Jaume Just.

36 De l'orde de Sant Domènec eren Gabriel Soria (autor del sermó de Divendres Sant del 1474), Ramon Damià i Lluís Navarro; Dionís Fernandes era de l'orde de Sant Jeroni. 


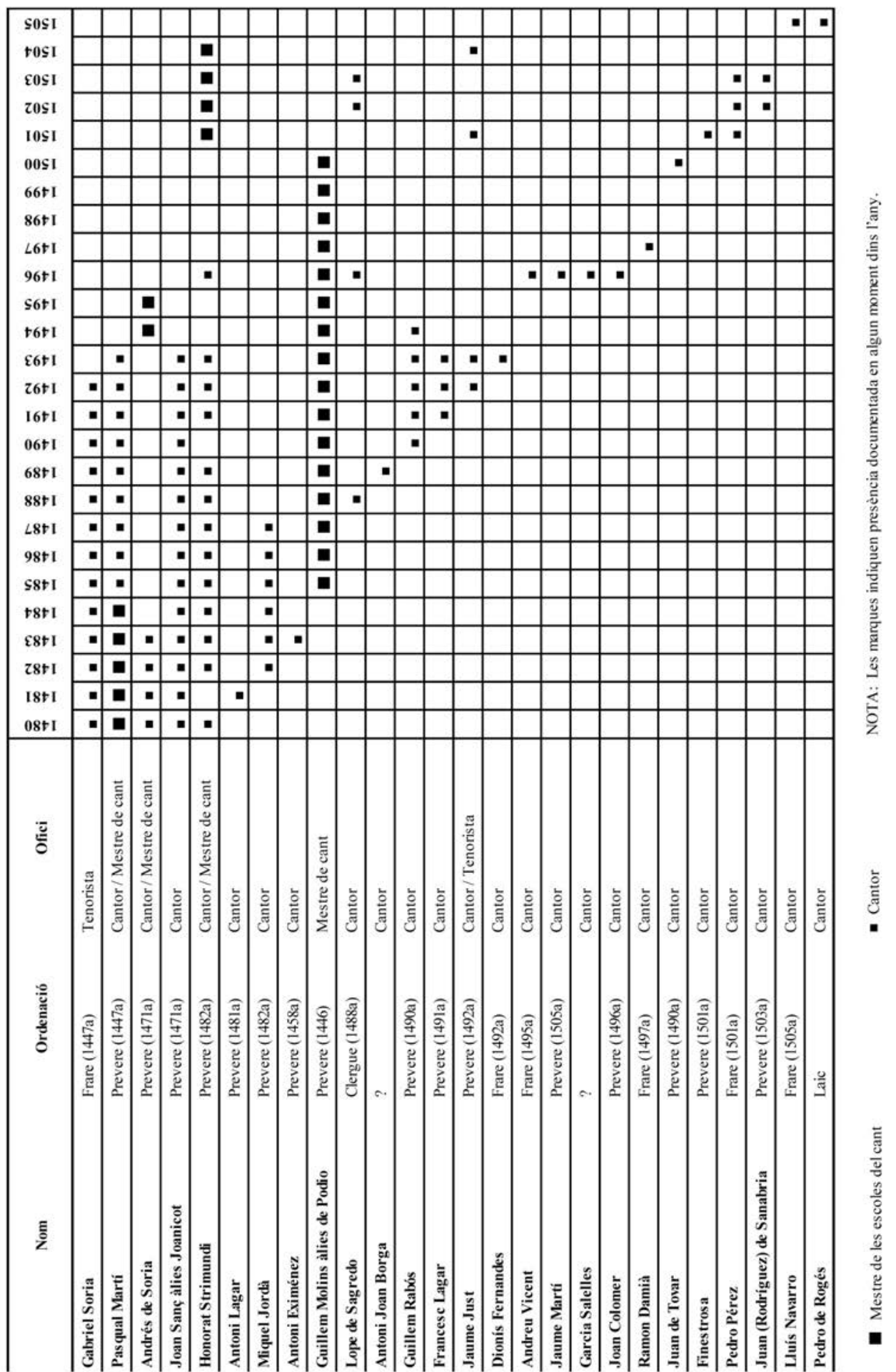

Taula 2. Mestres de les escoles del cant i cantors identificats, 1480-1505. 
No obstant les limitacions de les dades disponibles, és possible albirar l'existència d'almenys dos tipus de perfils professionals entre els cantors de la catedral. D'una banda, gran part d'aquells que van residir un llarg període a la seu i que no consta que hagueren servit en altres institucions musicals fora de la ciutat responien segurament al prototip de músic local, fonamentalment nadiu, i probablement amb coneixements o habilitats no excessivament destacables, la qual cosa no els hauria facilitat la mobilitat professional ${ }^{37}$. Però això no significa que no comptaren amb una adequada formació musical que, almenys en un parell de casos -Guillem Rabós i Jaume Martí-, consta que incloïa coneixements de tècnica instrumental puix se sap que, respectivament, tenien un "címbol" i un curiós instrument que és descrit com un "cimbol e harpa tot en una peça". Malgrat la notable estabilitat laboral d'aquests músics, s'ha pogut registrar algun intent de moviment interessant, com ara el del tenorista Gabriel Soria, qui fou requerit el 1458 per Alfons el Magnànim per a incorporar-se al servei reial a Nàpols, encara que possiblement no arribà a fer-ho a causa de la immediata mort del sobirà, i va romandre a València durant més de tres dècades fins la fi dels seus dies. També s'han constatat absències breus per viatges a llocs desconeguts - d'Honorat Strimundi i de Jaume Just- o conegut, com ara el d'Andrés de Soria a Roma el 1484. El cas de Guillem Rabós mostra el moviment d'un músic nadiu exclusivament dins de la ciutat de València entre la seu, la capella del virrei i la tornada a la catedral. En morir aquest músic el 1517, posseïa, a més de diversos llibres de religió, alguns litúrgics, de cant -un d'ells consta que era de cant d'orgue- i, fins i tot, tractats musicals -un parell segurament de cant pla, puix són descrits com Arts de cant ${ }^{38}$. Els cantors nadius i laboralment estables eren segurament els més proclius a integrar-se en

37 En aquesta categoria almenys es podrien incloure Gabriel Soria, Pasqual Martí, Andrés de Soria, Joan Sanç, Guillem Rabós o, fins i tot, Honorat Strimundi, malgrat no ser valencià. Possiblement Jaume Just també s'integraria en aquest grup, malgrat que d'un gran nombre d'anys no s'ha pogut localitzar informació, atenent a l'aparent continuïtat de la seua trajectòria a la seu que s'entreveu al llarg de quatre dècades.

38 Llibres litúrgics: "un breviari vell", "un libre que-s diu lo dominical de mà vell squinsat", "un libre de un ofici per a temps de Pasce", "un libre de passis e molts papers", "un processional". Llibres de cant: "dos llibres grans de cant vulgarment dits oficiers, los quals se diu són de la seu de la dita ciutat de València", "un libre de cant d'orgue de forma major", "altre libre de cant de forma chiqua", "molts qüerns desusits de oficis de cant", "un libre de cant cubert de posts", "dos libres chichs de cant". Tractats: "altre libre de l'art del cant", "un libre de art de cant de stampa" i potser "un libre de Boeti de stampa". Pot consultar-se el darrer testament, inventari i encant dels béns -a excepció dels objectes domèstics, aliments i indumentària- de Guillem Rabós dins VILLANUEVA SERRANO (2015): vol II, p. 437-443. la confraria de la Verge Maria de la Seu, vinculada des dels orígens als sacerdots de la catedral, com s'ha pogut constatar en un parell de $\operatorname{casos}^{39}$.

Però, d'altra banda, la seu valenciana també va ser tan sols una estació més en la trajectòria professional d'altres músics, fonamentalment forans, els quals, a més, es van distingir per mostrar una superior competència professional. D'aquesta circumstància és testimoni el fet que, almenys quatre dels cinc que s'ajusten clarament a aquest perfil, van assolir en alguna ocasió l'ofici de mestre de cant en institucions peninsulars, fonamentalment catedralícies (vegeu la taula 3). Atenent a les dades conegudes, també quatre dels cinc es van moure exclusivament en l'àmbit geogràfic i polític de la Corona d'Aragó, fonamentalment a la cort reial i a les catedrals de les principals ciutats peninsulars. Antoni Eximénez i Guillem de Podio, músics aleshores veterans, havien exercit tant a la cort de Joan II com a catedrals catalanes -a Lleida el primer; a Barcelona i a Girona el segon-. D'altra banda, Juan de Tovar i Lope de Sagredo, més joves, estigueren vinculats a Saragossa durant el període d'estudi o posteriorment -el primer a $L a S e o$ i el segon a l'arquebisbe Juan de Aragón així com, posteriorment, també a La Seo-. El cas de Juan de Tovar és particular, no només pel fet que va passar dues vegades per la seu valenciana separades per vint anys de diferència, sinó perquè allí va exercir primerament com a simple cantor (1500) -malgrat que el 1490 ja havia sigut mestre de cant a Saragossa- i, després, com a mestre de capella (1520-1521).

39 Es tracta de Pasqual Martí i Guillem Rabós. Sobre aquesta confraria, vegeu TEIXIDOR (1895): vol. II, 347-350. 
Antoni Eximénez

\begin{tabular}{|c|} 
Seu de Lleida \\
Mestre de cant \\
$1439-1445 ?$ \\
\hline CATEDRAL DE \\
VALÈNCIA \\
Cantor \\
$\mathbf{1 4 5 8}$ \\
\hline
\end{tabular}

Capella de Joan II d'Aragó

Cantor

$1458-1474$ ?
Guillem de Podio Lope de Sagredo Juan de Tovar

Seu de Barcelona

Mestre de cant

1446-1458

Capella de Joan II d'Aragó

Cantor

1458-1479

Capella de la reina Joana

Mestre de capella

1458?-1468

Seu de Girona

Lloctinent de cabiscol mitjà

1471-1479

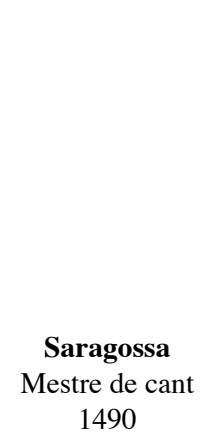

Juan de Sanabria

\author{
Catedral de Burgos \\ Cantor \\ 1484 \\ Catedral d'Àvila \\ Mestre cantor \\ 1487 \\ Catedral de Lleó \\ Cantor \\ 1494
}

Catedral de Múrcia?

Cantor

1502

\begin{tabular}{|c|c|c|c|c|}
\hline $\begin{array}{c}\text { CATEDRAL DE } \\
\text { VALÈNCIA } \\
\text { Cantor } \\
\dagger 1483\end{array}$ & $\begin{array}{l}\text { CATEDRAL DE } \\
\text { VALÊNCIA } \\
\text { Mestre de cant } \\
1485-\dagger 1500\end{array}$ & $\begin{array}{l}\text { CATEDRAL DE } \\
\text { VALÈNCIA } \\
\text { Cantor } \\
\text { 1488, 1496, 1502-4 }\end{array}$ & $\begin{array}{c}\text { CATEDRAL DE } \\
\text { VALÊNCIA } \\
\text { Cantor } \\
1500\end{array}$ & $\begin{array}{l}\text { CATEDRAL DE } \\
\text { VALÈNCIA } \\
\text { Cantor } \\
\text { 1502-1503 }\end{array}$ \\
\hline & & $\begin{array}{c}\text { Arquebisbe de } \\
\text { Saragossa } \\
\text { Cantor } \\
1516\end{array}$ & $\begin{array}{l}\text { CATEDRAL DE } \\
\text { VALÈNCIA } \\
\text { Mestre de capella } \\
\text { 1520-1521? }\end{array}$ & \\
\hline & & $\begin{array}{c}\text { La Seo de Saragossa } \\
\text { Cantor } \\
1530-1532\end{array}$ & & \\
\hline
\end{tabular}

Taula 3. Músics amb trajectòria professional identificada fora de València, 1480-1505.

L'únic d'aquests músics de qui es coneix que havia desenvolupat una trajectòria professional a Castella fou Juan Rodríguez de Sanabria, sovint anomenat simplement Juan de Sanabria. Però no només aquesta circumstància el fa singular entre la resta, sinó el fet que és l'únic músic de la seu en el període d'estudi, i el més primerenc conegut en la història de la institució, de qui actualment es conserva música pràctica de la seua autoria. Es tracta de dos villancicos castellans continguts en el Cançoner de Palau, així com un himne i un motet copiats en el manuscrit 2-3 de la catedral de Tarassona, tots ells amb atribució a "Sanabria" o a "Jo. de Sanabria"40. La carrera professional fins ara coneguda de Juan de Sanabria

40 Mayoral [E-Mp, II-335, f. 70v-71r; núm. 118 de l'edició ANGLÉS (1951): vol. II, 143]; Descuidad d'ese cuidado [ibid., f. 251v; núm. 377 de l'edició ANGLÉS (1951):vol III, 136]; himne Cuius corpus Sanctissimum [E-TZ, ms. 2-3, f. 7v-8r; edició dins GERBER (1957): 6-7]; motet Lillium sacrum [E-TZ, ms. 2-3, f. 110v-111r; edició dins CALAHORRA MARTÍNEZ (1995): 139-143]. el vinculava a les catedrals de Burgos (cantor, 1484) ${ }^{41}$, Àvila (maestro cantor, 1487) ${ }^{42}$ i Lleó (cantor, 1494) ${ }^{43}$, llocs on també havia exercit funcions docents en matèria de cant. Atenent a la cronologia i al perfil professional sembla probable la identificació d'aquest músic amb un cantor i també mestre anomenat Sanabria que va servir a la catedral de Múrcia fins poc abans del 30 de setembre de $1502^{44}$. De fet, probablement no fou casualitat que només uns dies més tard, el 5 d'octubre, Juan Rodríguez de Sanabria fou nomenat cantor a la catedral de València amb dos senyals de salari. El seu pas per la seu valenciana fou breu i, a més, sembla que no massa satisfac-

41 La presència a la catedral de Burgos fou primerament comunicada en LÓPEZ MARTÍNEZ, 2 (Burgos, 1961): 288. Posteriorment, han sigut publicats diversos documents dins LÓPEZ CALO (1996): 29-30.

42 MOLL ROQUETA, 22 (Barcelona, 1967): 90-92.

43 ÁLVAREZ PÉREZ, 14 (Barcelona, 1959), 42.

44 PRATS REDONDO (2009): 143. 
tori per al capítol, ja que el músic fou "despedit" el darrer dia de març de l'any següent. Es desconeix si l'estada a la ciutat de València es va perllongar durant més temps però degué ser suficient per a aconseguir cert predicament com a teòric, una faceta fins ara també desconeguda del músic. En efecte, una nota marginal al tractat Enchiridion de principiis musice discipline de Guillem de Podio informa que aquest darrer autor estava en contra de la doctrina de "Johannes de Sanabria et alii sui sequaces" en relació a un cas particular de la divisió del to ${ }^{45}$. L'ara coneguda condició de teòric d'aquest músic aconsella, per tant, no descartar la possibilitat que haguera sigut l'autor d'un tractat de cant pla, actualment desaparegut, que segons François Joseph Fétis es va publicar a Salamanca el 1504 per un personatge anomenat Juan Rodríguez, natural d'aquesta ciutat i "chantre" a la seua catedral ${ }^{46}$. D'altra banda, les noves dades procedents de València i, potser, de Múrcia semblen suficients per descartar la possibilitat, no qüestionada fins ara, que Juan Rodríguez de Sanabria es poguera identificar amb Juan Rodríguez de la Torre, cantor de la reina Isabel des del 3 d'octubre de 1495 fins a la mort de la monarca el 26 de novembre de $1504^{47}$, puix durant almenys sis mesos -de l'octubre de 1502 al març de 1503- el primer músic no hi fou a la cort castellana sinó a València i, potser, immediatament abans a la catedral de Múrcia ${ }^{48}$.

Atenent a la informació disponible, també hi ha alguna possibilitat que altres cantors de la seu pogueren haver format part d'institucions diferents al llarg de les seues carreres, malgrat que diverses dificultats impedeixen formular, ni tan sols, hipòtesis raonables al respecte. D'una banda, no es pot descartar que Pedro Pérez, actiu a la seu del 1501 al 1503, es poguera identificar amb Petrus Perez de Rezola, cantor de la diòcesi de Tortosa que el 1510 s'incorporava la capella papal, encara que el fet que el primer escriguera els albarans

45 I-Bc, ms. A.71, p. 148. Pot consultar-se el passatge concret en traducció al valencià/català dins VILLANUEVA SERRANO (2015): vol II, p. 31. Sobre la vinculació valenciana de I-Bc, ms. A.71, pot consultar-se VILLANUEVA SERRANO (2015): vol. I, p. 424-431.

46 FÉTIS (1878): vol. VII, 288. Atenent que el llibre de Fétis està en francès, amb el terme "chantre" l'autor segurament està fent referència a un simple cantor i no a una dignitat capitular, com caldria suposar si el text estiguera en castellà.

47 KNIGHTON (2001a): 342; (2001b): 893

48 Atès que la informació de la presència de Juan Rodríguez de la Torre a la cort de la reina Isabel, proporcionada per Knighton, era de caràcter anual, he hagut de comprovar amb detall, directament sobre les fonts, els sis assentaments de pagaments quadrimestrals de quitacions de Juan Rodríguez de la Torre en la cort de la reina Catòlica durant els anys 1502 i 1503 (6.666 maravedís/terça) i es pot confirmar que va cobrar-los tots complets [E-SIM, Casas y Sitios Reales, leg. 43, f. 148, $150,153,169,171,172]$. Agraïsc a Tess Knighton el seu tenaç esforç, malauradament infructuós, per localitzar aquesta informació quadrimestral en el seu arxiu personal. en castellà suggereix, en principi, un origen no català i, per tant, resta credibilitat a aquesta eventualitat. D'altra banda, el cantor Lluís Navarro que exercia a la seu valenciana el 1505 podria tractar-se del músic homònim que servia Alfons el Magnànim el 1451, però la llunyania cronològica aconsella no atorgar massa confiança a la possibilitat. Per últim, la manca del nom de bateig en l'únic document valencià que cita Finestrosa, cantor de la seu el 1501, no permet identificar-lo amb seguretat amb Miguel de Hinestrosa, el qual va servir a la capella de Ferran el Catòlic del 1503 al 1516.

La catedral també comptava en aquesta època amb quatre infants o fadrins anomenats diputats que, entre altres funcions auxiliars en la litúrgia, participaven en el cant, els quals estaven a cura d'un mestre dels diputats, diferent al de les escoles del cant ${ }^{49}$. Es coneixen només tres noms complets de diputats en el període d'estudi -Joan Çaragoça, Agostí Pastor i Nicolau Feliu- mercès als documents notarials que registren concessions de senyals atès que, quan deixaven aquest servei, els menors solien rebre una d'aquestes pensions per a sostenir-se mentre continuaven estudiant. L'únic mestre dels diputats que s'ha pogut identificar en el període d'estudi ha sigut Joan Montesino, un prevere que va estar més de tres dècades al servei de la seu i que va exercir aquest càrrec almenys del 1490 al 1498, la qual cosa no li va impedir assumir simultàniament altres oficis catedralicis com ara el de domer o el de sotsobrer. Entre les obligacions docents del mestre dels diputats degué estar present l'ensenyament musical. De fet, Montesino tenia coneixements de la disciplina puix posseïa a la seua mort un vell monacord, una flauta, i quatre passions notades lligades en pergamí de la probable autoria de Guillem de Podio ${ }^{50}$. Així mateix, consta que pocs anys abans i després de l'interval analitzat van ser sengles cantors -Pasqual Martí i Guillem Rabós- els qui s'encarregaren d'aquesta comesa.

\section{ORGANISTES}

El 1471 l'orguener alemany conegut com Pere Ponç va acabar de construir a la seu, després d'11 anys de tre-

49 Sobre els diputats i el seu mestre, vegeu VIILLANUEVA SERRANO, 64 (Barcelona, 2009): 82-85.

50 L'inventari post mortem de Montesino, datat el 20 de setembre de 1505 , només es pot llegir parcialment per haver desaparegut la tinta en gran part dels folis. Entre els béns inventariats hi havia: "Ítem quatre [...] ligats ab pergamí [...] de mestre Podio". L'encant, de 24 de setembre de 1505 , aclareix una mica més de què es tractava, malgrat que no totalment: "Ítem, quatre passis notats e ligats cascú per sí ab cubertes de pergamí, a frare Navarro de Preïcadors, per XXI sous" [E-VAcp, not. Guillem Ramon Tovia, vol. 26408, s/f]. Els instruments figuren amb les descripcions "una flauta de coure (roure?) per a sonar" i "un monacord vell" [ibid.]. 
balls, l'orgue major de cinc seccions amb cinc teclats que es va instal-lar sota el primer arc existent entre la nau central i la del costat de l'Evangeli, un instrument veritablement monumental que, fins $\mathrm{i}$ tot, va servir de model per al que es va fabricar uns anys més tard a La Seo saragossana ${ }^{51}$. A la part contrària del cor hi havia uns orgues més antics que es van substituir per l'orgue menor que va construir l'orguener i músic Marturià Prats entre el 1483 i el 1485. Només tres anys després, s'iniciaren uns rellevants treballs que modernitzaren l'orgue major, a càrrec de l'alemany conegut com Joan Spindelnoguere, els quals es prolongaren durant any i mig ${ }^{52}$. Tant les obres de Prats com les de Spindelnoguere es van executar mentre Onofre Ferrer era l'organista de la seu. Aquest músic era fill de l'anterior titular, Joan Ferrer àlies de l'Ardiaca, i va començar el servei a la catedral com a laic el 1477, encara en vida de son pare. Segurament era convenient que l'organista de la seu fóra un prevere i, potser per això, es va ordenar alguns anys més tard. Així mateix, foren sacerdots i músics locals els successors en l'ofici, anomenats Joan Trossera i Pere Castell. Aquests organistes exerciren conjuntament el càrrec des del 1492 repartint-se a parts iguals el salari de 40 lliures anuals, bastant superior al dels cantors. Potser la raó d'aquesta peculiar forma d'exercici de l'ofici, que es va perllongar fins l'arribada del català Pere Vila gairebé 20 anys després, fóra el fet que ambdós eren beneficiats de la seu i d'aquesta manera podien compatibilitzar totes les seues obligacions. Com a músics locals, Trossera i Castell també formaven part de confraries valencianes, de Sant Jaume i de la Verge Maria de la Seu, respectivament. El segon d'aquests organistes va morir el 1514 , anys després de retirar-se de 1'ofici, moment en què se sap que posseïa dos monacords i un petit orgue, malgrat que el darrer instrument aleshores es trobava prestat a una casa de la noblesa valenciana.

\section{CONCLUSIÓ}

Aquest estudi ha permès confirmar, d'una banda, la diferenciació socioeconòmica existent entre els elitistes membres capitulars titulars de les dues principals àrees de responsabilitat musical a la seu valenciana-cabiscol i canonge rector de les escoles del cant- $\mathrm{i}$ la resta de personal, que s'ubicava en un perfil de beneficiat o assimilable. En el darrer grup, també es pot apreciar, en general, una lleugerament superior posició econòmica i d'estatus en els oficis de

51 Sobre aquest instrument, vegeu VILLANUEVA SERRANO, 64 (Barcelona, 2009); 7-31.

52 Sobre els treballs de Prats i Spindelnoguere, vegeu VILLANUEVA SERRANO, 30 (Saragossa, 2014a): 22-39. sotscabiscol, d'organista i, en alguns casos, de mestre de les escoles del cant, respecte dels cantors, circumstància segurament afavorida per les funcions més fortament estructurals a la catedral dels primers, que probablement van reflectir-se en majors ingressos totals per a aquests professionals. Entre els cantors, tot i que sembla que majoritàriament locals, es pot distingir un reduït grup de músics d'acreditada competència i d'origen forà que tingueren mobilitat professional a la península, tot i que, fonamentalment dins la Corona d'Aragó, atenent a les dades conegudes. Entre tots aquests, destaquen Guillem de Podio i Juan de Sanabria per ser els únics de qui es conserven obres escrites; teòriques en el primer cas $\mathrm{i}$ pràctiques en el segon.

Des del punt de vista metodològic, la prosopografia s'ha mostrat en aquest treball com una eina d'utilitat per a l'estudi d'un conjunt de persones vinculades a l'activitat musical en una institució. Naturalment, la potència del recurs i la robustesa de les conclusions assolides depenen de factors com ara el nombre de persones del grup, de la quantitat de dades recopilades per a cadascuna i de la varietat tipològica de les fonts consultades. Per això, cal remarcar la importància, en aquest tipus d'estudi, de treballar també en arxius diferents al de la institució analitzada; no només en els d'altres centres semblants sinó també en els que custodien diferents tipologies documentals, com ara els notarials, els diocesans o els de les administracions civils i reials. Malauradament, les fonts d'aquests darrers arxius sovint ofereixen a l'investigador un rendiment en el treball notablement inferior, a causa de la dispersió i la escassetat de les dades. Malgrat aquest inconvenient, les seues aportacions són de gran interès pel fet que permeten obrir perspectives molt més àmplies en les trajectòries professionals i en les circumstàncies socioeconòmiques i culturals dels membres del col·lectiu estudiat.

\section{Apèndix}

\section{Catàleg Prosopogràfic}

\section{NOTES PRELIMINARS}

Aquest apèndix és un recull prosopogràfic de personatges que tingueren algun càrrec institucional o ofici estable relacionat amb la música a la seu de València dins del període 1480-1505. Les entrades s'han ordenat per ordre alfabètic del cognom o identificatiu més habitual de cada personatge. També s'han incorporat independentment els identificatius alternatius o que tenen formes ortogràfiques significativament diferents, en els quals casos s'ha remès el lector a les corresponents entrades principals. Cadascuna d'aquestes segueix el següent esquema: 
1. Encapçalament. Inclou el nom del biografiat amb els possibles noms alternatius o sobrenoms darrere del mot "àlies". El nom de pila es normalitza però no el cognom o identificatiu, davant les múltiples possibilitats que presenten un gran nombre d'aquests. Es proporcionen entre claudàtors les variants ortogràtiques detectades $i$ entre parèntesis les paraules que no sempre apareixen en el nom. Quan hi ha algun dubte, s'assenyala amb un signe d'interrogació.

2. Cos. És una síntesi de la trajectòria vital del personatge. Quan hi ha moltes dades disponibles, s'ha optat per simplificar el text per a major claredat expositiva.

3. Imatge d'escrit autògraf. Només en alguns casos s'han localitzat escrits autògrafs del músic biografiat. En aquests supòsits, s'inclou un exemple gràtic.

4. Origen de la informació. Breus resums dels documents trobats en les fonts arxivístiques que s'han consultat directament i simples relacions de localització de cobraments, quan els conceptes no són rellevants, així com la bibliografia localitzada amb alguna aportació a la trajectòria del personatge o que es considera que ha sigut significativa historiogràficament.

\section{SIGLES DELS ARXIUS}

AAB Barcelona, Arxiu de l'Ateneu Barcelonès.

ADB Barcelona, Arxiu Diocesà.

ADG Girona, Arxiu Diocesà.

ADPV València, Arxiu de la Diputació Provincial de València.

ADV València, Arxiu Diocesà.

AHPB Barcelona, Arxiu HIstòric de Protocols.

E-Bac Barcelona, Arxiu de la Corona d'Aragó.

$E-B C \quad$ Barcelona, Arxiu de la Catedral.

E-G Girona, Arxiu de la Catedral.

E-LEc Lleida, Arxiu capitular.

E-Mp Madrid, Biblioteca del Palacio Real.

E-TZ Tarazona, Archivo de la Catedral.

E-VAar València, Arxiu del Regne de València.

E-VAc València, Arxiu de la Catedral.

E-VAcp València, Arxiu del Reial Col-legi-Seminari de Corpus Christi.
Joan Aragonés $\rightarrow$ Joan Çaragoça àlies Aragonés

Joan de l'Arthiaca $\rightarrow$ Joan Ferrer àlies de l'Arthiaca

\section{Joan Balaguer}

Sotscabiscol / Catedral de València

Va ocupar una de les dues sotscabiscolies de la seu de València, almenys durant el període del 1491 al 1522.

Documents

- 11 d'octubre de 1491. És sotscabiscol de la seu de València [E-VAc, Armari auxiliar de fàbrica, vol. 1332, any 1491, $\mathrm{s} / \mathrm{f}]$.

- 4 de juliol de 1509. És sotscabiscol de la seu de València [E-VAc, Fàbrica, vol. 1485, any 1491, f. 18r].

- Any administratiu de 1522. Cobra un senyal per la sotscabiscolia [E-VAc, Almoina, Pagador dels senyals, vol. 5614 , any $1522, \mathrm{~s} / \mathrm{f}]$.

\section{Antoni Joan Borga [=Borga]}

Cantor / Catedral de València

L'1 de juliol de 1489 va ingressar com a cantor a la catedral de València amb salari de dos senyals. Es desconeix quant de temps continuà en l'ofici.

Document

- 1 de juliol de 1489. Antoni Joan Borga [Borja] és admès com a xantre de la seu de València amb salari de 2 senyals [E-VAc, not. Jaume Esteve, vol. 3685, s/f].

Antoni Joan Borja $\rightarrow$ Antoni Joan Borga

\section{Joan de Borja}

Cabiscol / Catedral de València

Fill de Jofré Borja-Llançol de Romaní i de Joana de Montcada, va ser nomenat canonge de la seu de València el 1480. El 1489 posseïa la dignitat de cabiscol i continuava sent-ho el 1492. A partir del 1494 es trobava a Itàlia ocupant diversos càrrecs civils i religiosos, fins arribar a ser arquebisbe de Pàdua. Va morir a Urbino el 1500 i fou soterrat a l'església de Santa Maria del Popolo de Roma.

\section{Documents}

- 29 de maig de 1480. És nomenat canonge de la seu de València [E-VAc, not. Joan Esteve, vol. 3596. f. 2r].

- 23 de maig de 1489. És cabiscol, canonge i paborde de setembre a la seu de València [E-VAc, not. Jaume Esteve, vol. 3597 , f. 186v].

- 23 de juny de 1492. És cabiscol de la seu de València [E-VAc, not. Jaume Esteve, vol. 3686, s/f].

Bibliografia

PONS ALÓS i CÁRCEL ORTÍ, 35:2 (Barcelona, 2005): 923. 


\section{Joan Çaragoça àlies Aragonés}

Diputat / Catedral de València

Va ser diputat de la seu de València. Possiblement després va continuar algun any més en contacte amb la seu beneficiantse del senyal que els capitulars solien atorgar als antics diputats. De qualsevol manera, el maig de 1496 havia deixat de gaudir d'ell.

Document

- 9 de maig de 1496. El capítol de València ordena que el senyal que tenia com a diputat o antic diputat siga adjudicat al cantor Honorat Strimundi [E-VAc, not. Jaume Esteve, vol. $3687, \mathrm{~s} / \mathrm{f}]$.

\section{Pere Castell}

Organista / Catedral de València

Va començar a exercir com a prevere organista de la seu de València a mitjan 1492, segurament el 9 de juny, compartint l'ofici i el salari amb Joan Trossera, el qual havia sigut nomenat un any abans en el càrrec. No obstant això, poc després de la incorporació de Castell, ambdós van aconseguir un increment salarial de 5 lliures, a més de les 20 lliures que rebia cadascun d'ells. Encara aquest mateix any, participava com a expert, juntament amb Guillem de Podio, en la visura de l'orgue de la parròquia valenciana de Sant Joan del Mercat, començat per l'orguener Pere Ponç però acabat per Joan Spindelnoguere. També posseïa un benefici en la mateixa catedral sota l'advocació de Maria Magdalena i era membre de la confraria de la Verge Maria de la Seu. El 1501 tenia un germà que cobrava anualment per espolsar les cadires del cor de la catedral. Sense incidències destacables, va exercir el càrrec compartit amb Trossera fins l'arribada de Pere Vila a mitjan 1510. Va morir en sa casa de València, prop del carrer de la Farina, el 18 de març de 1514, probablement a conseqüència d'una apoplexia ("ploxexia"). Entre els béns que en aquest moment posseïa, hi havia dos monacords $\mathrm{i}$ un petit orgue, que solia deixar als seus amics. Va nomenar hereu universal al seu nebot Sebastià Gil, sabater, resident a Barcelona.

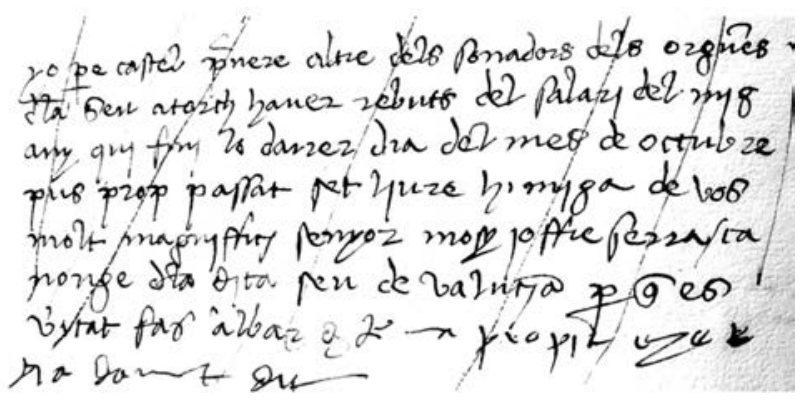

[E-VAc, Tresoreria, vol. 1291, any 1497, s/f]

\section{Documents}

- 14 de desembre de 1492. Cobra per primera vegada com a organista de la seu de València per un període que comença el 9 de juny de 1492 [E-VAc, not. Jaume Esteve, vol. 3686, any $1492, \mathrm{~s} / \mathrm{f}]$.

- 22 d'agost de 1492. El capítol de la seu de València li concedeix un augment de sou de 5 lliures com a organista, al mateix temps que a Joan Trossera $[E-V A c$, not. Jaume Esteve, vol. 3605, s/f].

- 21 d'octubre de 1492. Acta de visura de l'orgue fet a la parròquia de Sant Joan del Mercat de València per Joan Spindelnoguere [E-VAcp, not. Bartomeu de Carries, vol. 20444, s/f].

- 9 de febrer de 1511. És prevere i té una criada anomenada Eulàlia Balmes, a la qual reconeix deure les 10 lliures que li deixa en el seu testament [E-VAar, not. Joan Fenollar, vol. 3105, s/f].

- Cobraments: E-VAc, Tresoreria, vol. 1291, any 1494, s/f; ibid., any 1497, s/f; ibid., any 1498, s/f; ibid., vol. 1292, any 1505, s/f; ibid., any 1506, s/f; ibid., any 1508, s/f; ibid., any 1509, s/f; ibid., any 1510, s/f. E-VAc, Fàbrica, vol. 1486, any 1501 , f. 21 v, 22v. E-VAc, not. Jaume Esteve, vol. 3686, any 1492, s/f, 14 de desembre de 1492; ibid., vol. 3687, any 1494, s/f, 27 d'octubre de 1494; ibid., any 1496, s/f, 6 d'abril de 1496; ibid., any 1497, s/f, 13 d'abril de 1497; ibid., any 1498, s/f, 28 d'abril de 1498, 12 de novembre de 1498; ibid., vol. 3688, any 1500, s/f, 19 de març de 1500; ibid., any 1502, s/f, 18 d'abril de 1502; ibid., any 1503, s/f, 21 d'abril de 1503 ibid., vol. 3689, any 1507, s/f, 19 d'abril de 1507. E-VAc, not. Felip Abella, vol. 3698, any 1508, f. 97v, 25 de setembre de 1508; ibid., any 1509, f. 115r, 4 d'abril de 1509; ibid., any 1510, f. 212r, 8 d'agost de 1510; ibid., f. 197r.

Bibliografia

VILLALMANZO, 12 (València, octubre-desembre 1984): 14-21, 24-28. VILLANUEVA SERRANO, 64 (Barcelona, 2009): 94; 34:1 (Madrid, 2011): 54.

\section{Joan Colomer}

Cantor / Catedral de València

El 15 de juliol de 1496 va ingressar com a prevere cantor a la catedral de València amb el dret a rebre percaços però sense senyals. El capítol va concedir-li el dret de continuar servint a la parròquia valenciana de Sant Martí, on era beneficiat. Es desconeix quant de temps continuà com a cantor de la seu. El seu nom no torna a aparéixer en les fonts consultades.

\section{Documents}

- 15 de juliol de 1496. El capítol de la seu de València l'admet com a cantor amb els percaços i amb la dispensa de poder seguir servint a la parròquia de Sant Martí [E-VAc, not. Jaume Esteve, vol. 3687, s/f]. 


\section{Jaume Conill}

Canonge rector de les escoles del cant / Catedral de València

Originari d'Oliva, va ingressar com a canonge a la seu de València el 1488. Era mestre en arts i sacra teologia. Va posseir diversos beneficis al regne valencià. Almenys durant el període 1491-1494 va exercir de vicari general de la diòcesi. L'any administratiu de 1495 va ser triat pel capítol com a canonge rector de les escoles del cant, sota el qual Guillem de Podio va treballar com a substitut o mestre de cant.

\section{Documents}

- 1 d'agost de 1488. Pren possessió d'una canongia a la seu de València [E-VAc, not. Joan Esteve, vol. 3596. f. 2r].

- 30 d'abril de 1495. És nomenat canonge rector de les escoles del cant de la seu de València $[E$-VAc, not. Joan Esteve, vol. 3596, f. 133r-133v, 138r].

\section{Bibliografia}

PONS ALÓS i CÁRCEL ORTÍ, 35:2 (Barcelona, 2005): 930.

\section{Ramon Damià}

Cantor / Catedral de València

L'1 de març de 1497 va ingressar com a cantor a la catedral de València amb els percaços i salari de dos senyals. Era frare de l'orde de Sant Domènec. Es desconeix quant de temps continuà com a cantor de la seu. El seu nom no torna a aparèixer en les fonts consultades.

\section{Document}

- 1 de març de 1497. És admès pel capítol de la seu de València com a xantre amb percaços $\mathrm{i}$ els dos senyals vacants per absència de Lope de Sagredo [E-VAc, not. Jaume Esteve, vol. 3687, any 1497, s/f].

\section{Miquel Dassió}

Canonge rector de les escoles del cant / Catedral de València El 24 de febrer de 1493 va ingressar com a canonge a la catedral de València.

\section{Document}

- 14 de febrer de 1493. Pren possessió d'una canongia a la seu de València [ $E$-VAc, not. Joan Esteve, vol. 3596. f. 2v].

\section{Martí Enyego}

Cabiscol - Canonge rector de les escoles del cant / Catedral de València

Era oncle de Roderic de Borja, després papa Alexandre VI, i mestre en sacra teologia. El 17 de setembre de 1471 va obtenir un canonicat a la seu de València. Va actuar com a vicari general de la diòcesi, almenys en el període 1479-1492. El 1483 va ser comissionat pel capítol per signar el contracte de construcció d'un orgue amb el cantor i l'orguener Marturià Prats. Del 1484 al 1487 fou inquisidor de València juntament amb Juan de Épila. El 2 de febrer de 1485, després de la mort de Guillem de Vich rebé la cabiscolia però el 1489 ja no la posseïa. L'any administratiu de 1496 va ser triat pel capítol com a canonge rector de les escoles del cant però no va nomenar un substitut o mestre de cant. Va participar en diversos certàmens poètics i fundà el benefici de la Verge de l'Esperança a la seu. Morí a València el 1508.

Documents

- 17 de setembre de 1471. Pren possessió d'una canongia a la seu de València [E-VAc, not. Joan Esteve, vol. 3596. f. 2r]. - 5 de febrer de 1483. Va ser comissionat pel capítol per signar un contracte amb l'orguener Marturià Prats per construir un orgue a la seu de València $[E-V A c$, not. Joan Esteve, vol. 3683, s/f].

- 2 de febrer de 1485. Pren possessió de la dignitat de cabiscol de la seu de València per mort de Guillem de Vich [E-VAc, not. Joan Esteve, vol. 3683, s/f].

- 29 d'abril de 1496. És triat pel capítol de la seu de València com a canonge rector de les escoles del cant $[E-V A c$, not. Joan Esteve, vol. 3596, f. 134r-134v, 137r].

Bibliografia

PONS ALÓS i CÁRCEL ORTÍ, 35:2 (Barcelona, 2005): 932. HINOJOSA (2002): vol 2, p. 499.

\section{Honorat Estramundi $\rightarrow$ Honorat Strimundi}

\section{Antoni Eximénez [Eximéniz, Ximénez, Ximeno]}

Cantor / Catedral de Lleida - Catedral de València - Capella de Joan II

El 14 de febrer de 1439 era mestre de cant de la catedral de Lleida, on també s'ocupava dels petits escolars. Sembla que va mantenir l'ofici fins al 1445, puix l'11 d'octubre d'aquest any va ser substituït pel capítol lleidatà, davant la seua absència. El 23 d'agost de 1458 era prevere cantor de la seu de València i rebia llicència del capítol fins al 13 de desembre per a anar a la seua "pàtria" per negocis propis. Sembla que allò que vertaderament pretenia era incorporarse a la capella reial com a cantor, puix el 22 de febrer de 1459 ja es trobava formant part d'aquesta institució, que acompanyava el monarca en la primera visita com a rei a la ciutat de València. Va aprofitar l'estada a la capital valenciana per a resoldre assumptes pendents amb la catedral com ara la devolució d'una casa pertanyent a l'administració de Dobles i Aniversaris que encara estava en el seu poder. El mes d'agost de 1459 encara estava a València, malgrat que el rei ja havia marxat. Abans de tornar a la cort va nomenar 
procuradors per a prendre possessió de beneficis a les diòcesis de València i altres properes així com per a demanar al capítol valencià l'adjudicació d'un benefici vacant a la seu. Mentre seguia al servei de Joan II, el 1466 obtingué i va gaudir, malgrat que potser per error, d'un benefici de patronat reial a la seu de València sota l'advocació de Sant Jaume, al qual renuncià el setembre de 1468. Possiblement, el motiu de la resignació estiguera relacionat amb l'imminent atorgament al mateix músic, per part del rei, de la rectoria del palau del Real a València que, a més, tenia un benefici annex a la mateixa seu. El rei va presentar-lo el 5 d'octubre d'aquest any al temps que revocava una presentació anterior feta a Pere Pau Rossell, fill de l'escrivà de ració de la casa reial. Amb tota seguretat, ja havia pres possessió d'aquesta rectoria al començament del gener de 1469. Probablement prompte abandonà la cort, sense perdre la condició de capellà reial, per a instal-lar-se definitivament a València, on va exercir personalment la rectoria del Real. De fet, són abundants els documents que proven la seua presència en aquesta ciutat i l'activitat en aquest càrrec, almenys des del 1474. En la tasca organitzativa, segurament va ser qui va impulsar el 1481 l'aprovació d'unes ordinacions per al bon funcionament de la petita capella que hi havia, i que regia, al palau reial de València. Sembla que a la fi de la seua vida va aconseguir, a més, ser admès com a cantor de la seu de València, una condició que pot constatar-se únicament en un document datat el 7 de març de 1483. Va morir entre aquest dia i el 16 d'abril del mateix any, presumiblement a València. Documents

- Any 1439. Rep 80 sous de la catedral de Lleida com a mestre dels escolars per una terça del manteniment de l'escolar valencià Pere Llançol $[E-L E c$, Comptadoria, comptes dels escolans, vol.P3B_M5_P1_C01,f. 13v].

- 23 d'agost de 1458. Rep llicència del capítol de la seu de València per a viatjar a la seua "pàtria" $[E-V A c$, not. Joan Esteve, vol. 3679, s/f].

- 22 de febrer de 1459. Forma part de la capella reial de Joan II quan nomena procurador per a fer gestions davant el papa [E-VAcp, not. Mateu Cirera, vol. 21868, s/f].

- 29 de març de 1459. Lliura al canonge administrador de Dobles i Aniversaris de la seu de València una casa que tenia d'aquesta administració en la parròquia de Sant Bartomeu [E-VAc, not. Joan Esteve, vol. 3679, s/f].

- 13 d'agost de 1459. Nomena procuradors per a prendre possessió de qualsevol benefici vacant a les diòcesis de València, Tortosa o Sogorb [E-VAc, not. Joan Esteve, vol. $3679, \mathrm{~s} / \mathrm{f}]$.

- 28 d'agost de 1459. Demana al capítol de València que li conferisquen un benefici vacant [E-VAar, Reial Cancelleria, reg. 280 , f. 166r-166v].
- Any administratiu de 1466. Com a xantre de la capella reial, el monarca li atorga un benefici de Sant Jaume a la seu de València [E-VAc, Terç de benifets d'absents, vol. 4039, any 1466 , s/f].

- Any administratiu de 1467. Té un benefici de Sant Jaume a la seu de València però hi és absent, atès que paga el terç [E-VAc, Terç de benifets d'absents, vol. 4039, any 1467, f. $8 \mathrm{r}]$.

- 1 de setembre de 1468. Com a xantre del rei, renuncia al benefici de Sant Jaume de la seu de València. El temps anterior de l'any administratiu del 1468 hi era absent [E-VAc, Terç de benifets d'absents, vol. 4039, any 1468, f. 2r].

- 5 d'octubre de 1468. Joan II el presenta a la rectoria del Real de València i benefici adjunt, que estaven vacants, i revoca una altra anterior feta a Pere Pau Rossell, fill de l'escrivà de ració [E-VAar, Reial Cancelleria, reg. 292, f. 42r]. La rectoria del Real tenia annex un benefici de Santa Llúcia a la seu [E-VAar, Batllia General, Lletres i privilegis, vol. 1157, f. 414r-418v].

- 8 de gener de 1469. Com a rector del Real, reconeix haver rebut 100 sous pels seus treballs de cobrar els censals, corresponents a l'any 1468, que estaven assignats als beneficis instituïts en la capella d'aquest palau [E-VAar, Batllia General, Àpoques, vol. 52a, f. 95r-95v].

- 2 de març de 1470. Joan II reconeix que Eximénez, capellà del rei i rector del palau del Real de València, havia posseït el benefici de Sant Jaume de la seu per error ja que no havia mort l'anterior posseïdor [E-VAar, Reial Cancelleria, reg. 291, f. 184r].

- 5 d'octubre de 1474. És rector de l'església del palau del Real de València on hi és present [E-VAar, Batllia General, Lletres i privilegis, vol. 1155, f. 297r-299r, 309v-311r].

- 6 de juny de 1475. Joan II ordena que les quitacions d'Eximénez del terç del gener a l'abril de 1475 es repartisquen entre els capellans i xantres de la capella, ja que Eximénez havia estat absent de la cort [E-Bac, Cancelleria Reial, reg. 3420, f. 82v-83r].

- 6 d'agost de 1476. És rector de l'església del palau del Real de València on hi és present [E-VAar, Batllia General, Lletres i privilegis, vol. 1155, f. 716v-718r].

- 9 de novembre de 1478. És rector de l'església del palau del Real de València on hi és present [E-VAar, Batllia General, Lletres i privilegis, vol. 1156, f. 309r-312v].

- 23 de desembre de 1481. Es decreten les ordinacions per al bon funcionament de la capella del palau del Real amb la presència del rector Antoni Eximénez [E-Bac, Cancelleria Reial, reg. 3637, f. 132r-134v].

- 14 de febrer de 1482. És rector de l'església del palau del Real de València, on hi és present [E-VAar, not. Jaume Piles, vol. 1826, s/f]. 
- 13 de maig de 1482. És rector de la capella del palau del Real de València i beneficiat de Santa Llúcia a la seu de València, on hi és present [E-VAar, not. Joan de Campos (junior), vol. 443, s/f].

- 4 de març de 1483. Nomena procurador a l'antic cantor de Joan II Lluís Domínguez àlies Adzuara per cobrar i anar a judicis en allò referent a la rectoria del Real de València [E-VAcp, not. Bartomeu Bodí, vol. 14401, s/f].

- 7 de març de 1483. Compareix com a testimoni en un acta notarial com a xantre de la seu valenciana i rector del palau del Real [E-VAc, not. Joan Esteve, vol. 3683, s/f].

- 16 d'abril de 1483. Per mort d'Eximénez, s'atorga la rectoria del palau del Real de València a Miguel Pan y Vino, cantor de Ferran II [E-VAar, Batllia General, Lletres i privilegis, vol. 1157, f. 414r-418v].

- Cobraments (casa reial): E-VAar, Mestre Racional, vol. 8801, f. 80v, 163r; ibid. vol. 9815, f. 324v, 354v; ibid. vol. 8803, f. 71r, 92r; ibid. vol. 8804, f. 323r; ibid. vol. 8805, f. 58r, 78v, 149v; ibid. vol. 8807, f. 47r, 47v; ibid. vol. 8817, f. 78v; ibid. vol. 8819, f. 64r.

Bibliografia

ANGLÉS (1975b): 890. MUJAL ELÍAS (1975): 60.

Antoni Eximéniz $\rightarrow$ Antoni Eximénez

Honorat Extramundi $\rightarrow$ Honorat Strimundi

\section{Nicolau Feliu}

Diputat / Catedral de València

Va ser diputat de la seu de València. El 1497 va rebre un senyal per a estudiar gramàtica.

Document

- 7 de maig de 1497. El capítol li atorga el senyal que tenia Agostí Pastor, diputat, perquè estudie gramàtica $[E-V A c$, not. Jaume Esteve, vol. 3687, any 1497, s/f].

Dionís Ferdinand $\rightarrow$ Dionís Fernandes

\section{Dionís Fernandes [Ferràndiz, Ferdinand]}

Cantor / Catedral de València

Era frare de l'orde jerònim i va ser cantor de la seu de València, almenys des de l'any administratiu de 1492, amb salari d'un senyal. El 31 de gener de 1494 ja s'havia retirat.

\section{Documents}

- 31 de gener de 1494. A causa de la seua retirada, s'adjudica el seu senyal a Nicolau Rocha [E-VAc, not. Jaume Esteve, vol. 3605 , f. 51r].

- Cobraments: E-VAc, Almoina, Procura Major, vol. 5686, any 1492 , f. 18 r, 52 v; ibid., any 1493 , f. 43 v. $E-V A c$, not.
Jaume Esteve, vol. 3686, any 1493, s/f, 25 de maig de 1493, 7 de setembre de 1493 .

Dionís Ferràndiz $\rightarrow$ Dionís Fernandes

\section{Onofre Ferrer}

Organista / Catedral de València

Nascut probablement a València, era fill, potser il-legítim, de Joan Ferrer àlies de l'Ardiaca, ciutadà que des del 1444 va ser organista de la seu de València. Sembla que Onofre va començar a actuar en aquest ofici sense ordenar-se, quan encara vivia son pare el 1477. En morir aquest el mateix any, Onofre va restar com a únic organista de la seu amb un salari de 40 lliures anuals que pagaven entre les administracions de la Tresoreria (33) i la Fàbrica (7). Com a hereu universal de son pare, va vendre una casa de l'herència al carrer valencià de la Taverna del Gall. Va ordenar-se de diaca entre març de 1483 i maig de 1484. Abans de l'1 de desembre de 1485 ja era prevere. El 1487 va ser testimoni, juntament amb Guillem de Podio, del contracte subscrit per la catedral de València amb l'orguener alemany Joan Spindelnoguere per a reformar l'orgue major. Va cobrar el seu darrer salari de la Fàbrica l'any administratiu de 1489, per la qual cosa sembla que va exercir l'ofici almenys fins a l'abril de 1490. El 4 de febrer de 1491 ja havia mort, quan va ser nomenat Joan Trossera en l'ofici d'organista de la seu.

\section{Documents}

- 1 de març de 1473. El rei Joan II legitima Onofre Ferrer, fill de Joan Ferrer, ciutadà de València, tingut amb Antònia Ferràndiz [E-Bac, Cancelleria Reial, reg. 3462, f. 122r-122v].

- Any administratiu de 1477. Comença a percebre el salari d'organista de la seu de València amb el tractament de laic ("honorable en") [E-VAc, Fàbrica, vol. 1483, any 1477, s/f] - 26 de novembre de 1479. És arrendador de tots els drets i accions del magnífic Joan de Cervató, donzell senyor de Godella [E-VAc, not. Joan Esteve, vol. 3593, s/f]. 21 de març de 1481. Es ciutadà de València i organista de la seu quan cedeix al procurador del capítol el seu salari d'organista de 40 lliures [E-VAar, not. Ausiàs Sanç, vol. $2060, \mathrm{~s} / \mathrm{f}]$.

- 5 d'octubre de 1481. És "mestre de sonar òrguens", hereu universal de son pare Joan Ferrer àlies de l'Arthiaca, quan ven una casa d'aquesta herència en el carrer de la Taverna del Gall de València [E-VAcp, not. Manuel d'Esparza, vol. $11383, \mathrm{~s} / \mathrm{f}]$

- 5 de desembre de 1482. El capítol de la seu de València ordena al sotsobrer que pague a Onofre Ferrer 40 lliures del salari degut a Joan Ferrer [E-VAc, not. Joan Esteve, vol. $3683, \mathrm{~s} / \mathrm{f}]$. 
- 15 de març de 1483. Rep 43 lliures del sotsobrer de la seu de València degudes del temps de salari del seu pare Joan Ferrer per sonar l'orgue i aleshores no està ordenat $[E-V A c$, not. Joan Esteve, vol. 3683, s/f].

- 6 de maig de 1484. És diaca [E-VAc, not. Joan Esteve, vol. $3683, \mathrm{~s} / \mathrm{f}]$.

- 1 de desembre de 1485 . És prevere [E-VAc, not. Joan Esteve, vol. 3683, s/f].

- 7 de setembre de 1487. Contracte subscrit per la catedral de València amb l'orguener Joan Spindelnoguere per a reformar l'orgue major [E-VAc, not. Jaume Esteve, vol. $3685, \mathrm{~s} / \mathrm{f}]$.

- 4 de febrer de 1491. Joan Trossera és nomenat en l'ofici d'organista per mort d'Onofre Ferrer $[E-V A c$, not. Jaume Esteve, vol. 3686, s/f].

- Cobraments: E-VAc, Fàbrica, vol. 1483, any 1477, f. 9v; ibid., any 1478, f. 12r; ibid., any 1479, f. 17r; ibid., vol. 1484, any 1481, f. 40r; ibid., any 1482, f. 12r, 16v; ibid., any 1483 , f. 11 r; ibid., any 1484 , f. 10v; ibid., any 1485 , f. 20r, 21r; ibid., any 1486, f. 16r, 16v; ibid., any 1488, f. 20r; ibid., any 1489 , f. 9r. $E-V A c$, not. Joan Esteve, vol. 3682 , any 1478 , s/f, 1 de juny de 1478 ; ibid., any 1479,6 de novembre de 1479, 26 de novembre de 1479; ibid., vol. 3683 , any 1480 , s/f, 20 de juny de 1480,3 de novembre de 1480; ibid., any 1481, s/f, 22 de juny de 1481, 23 de juliol de 1481; ibid., any 1482, s/f, 20 de juliol de 1482; ibid., vol. 3683, any 1484, s/f, 6 de maig de 1484; ibid., any $1485, \mathrm{~s} / \mathrm{f}, 1$ de desembre de $1485 . E$-VAc, not. Jaume Esteve, vol. 3685, any 1487, s/f, 2 de març de 1487; ibid., any 1488 , s/f, 31 de juliol de 1488, 4 d'agost de 1488; ibid., any 1489, s/f, 7 de maig de 1489 .

Bibliografia

SANCHIS Y SIVERA (1909): 456, nota 1.

\section{Finestrosa}

Cantor / Catedral de València

Se sap que l'any administratiu de 1501 era cantor de la seu i es trobava malalt. Hi ha la possibilitat que es tractara de Francisco de Hinestrosa, el qual fou capellà i cantor d'Enric IV de Castella del 1457 fins, almenys, el 1464. Però, per cronologia, és més probable que es poguera tractar de Miguel de Hinestrosa, qui posteriorment fou, des del 1503 fins el 1516, cantor de la cort aragonesa de Ferran el Catòlic.

Documents

- Any administratiu de 1501. El procurador major de l'Almoina fa dos lliuraments econòmics al visitador dels malalts de la catedral com a subvenció de la malaltia de Finestrosa, prevere xantre de la seu [E-VAc, Almoina, Procura Major, vol. 5687, f. 41v].
Bibliografia

KNIGHTON (2001a): 82-83, 181-192. CAÑAS GÁLVEZ, 29:1 (Madrid, 2006): 278.

Joanicot $\rightarrow$ Joan Sanç àlies Joanicot

Jonichot $\rightarrow$ Joan Sanç àlies Joanicot

Joniquot $\rightarrow$ Joan Sanç àlies Joanicot

\section{Miquel Jordà}

Cantor / Catedral de València

El 1481 era estudiant escolar a la seu de València i a l'any següent era admès com a cantor amb un senyal de salari. Va actuar com a procurador del veterà cantor i mestre de cant valencià Lluís Domínguez per a cobrar. Va exercir el seu ofici fins, almenys, el 3 d'agost de 1487, moment a partir del qual es perden les seues empremtes.

Documents

- 20 de setembre de 1481. Era estudiant escolà ('studens scolaris") de la seu [E-VAc, not. Joan Esteve, vol. 3683, $\mathrm{s} / \mathrm{f}]$.

- 28 de març de 1487. Era cantor i procurador de Lluís Domínguez àlies Atzuara, antic cantor de Joan II, per a cobrar del senyor de Manises [E-VAar, not. Miquel Puigmicha, vol. 1917, s/f].

- Cobraments: E-VAc, Almoina, Procura Major, vol. 5658, any 1482 , f. 32 r; ibid., vol. 5685 , any 1483 , f. 34 v; ibid., vol. 5658, any 1484 , f. 33v; ibid., vol. 5685, any 1485 , f. $33 \mathrm{v}$; ibid., any 1486 , f. $33 \mathrm{v}$; ibid., any 1487 , f. $31 \mathrm{v}$. $E$-VAc, not. Joan Esteve, vol. 3683, any 1483, s/f, 20 de desembre de 1483; ibid., vol. 3683, any 1484, s/f, 22 de setembre de 1484, 24 d'abril de 1484. E-VAc, not. Jaume Esteve, vol. 3683, any 1487, s/f, 8 de maig de 1487, 3 d'agost de 1487.

\section{Jaume Just [de Sent Just]}

Cantor tenorista / Catedral de València

Ja era cantor prevere de la seu de València quan, el 20 d'agost de 1492 , fou admès a rebre els percaços de la catedral. Va estar absent durant uns mesos entre el 1500 i el 1501 durant els quals el capítol li retirà els dos senyals que tenia de salari. A partir del 1501 es citat amb frequiència com a tenorista en els documents. També gaudia d'un benefici a la col-legiata de Gandia, almenys del 1501 al 1504. Posseïa dues cases al carrer del Mestre de Montesa de València, les quals va vendre el 1504. El 1511, el seu salari a càrrec del pagador dels senyals era de 3 senyals, una quantitat que ja no es va augmentar més. Va mantenir l'ofici fins a la seua mort el 30 de juny de 1532 . 


\section{Documents}

- 20 d'agost de 1492. És xantre de la seu de València i és admès a rebre els percaços $[E-V A c$, not. Jaume Esteve, vol. $3605, \mathrm{~s} / \mathrm{f}]$.

- 30 d'octubre de 1500. El capítol de la seu de València li adjudica els seus dos senyals a Juan de Tovar, prevere [xantre] per estar Just absent [E-VAc, not. Lluís Esteve, vol. 3631, fora d'enquadernació].

- 16 d'abril de 1501. El capítol valencià li concedeix els dos senyals vacants per absència de Juan de Tovar $[E-V A c$, not. Lluís Esteve, vol. 3631, fora d'enquadernació].

- 20 d'octubre de 1501. Era tenorista de la seu de València i beneficiat de Sant Antoni a la col-legiata de Gandia quan nomena procurador a Joan Caro, mercader de Gandia, per a cobrar [E-VAar, not. Damià Burgal, vol. 345, s/f] .

- 23 de març de 1504. Era cantor de la seu de València i beneficiat a la seu de Gandia quan ven dues cases contigües en el carrer del Mestre de Montesa de València [E-VAcp, not. Guillem Exernit, vol. 23023, s/f].

- 8 d'agost de 1510. El capítol de València li restitueix el senyal que li havia llevat el 14 de juny de 1510 [E-VAc, not. Jaume Esteve, vol. 3698, f. 212r].

- 3 de setembre de 1530. Atorga rebut de cobrament al paborde de març de la seu de València per la quantitat de 7 lliures i 10 sous com a part de les 15 lliures que li dóna anualment [AHNN, Osuna, not. Joan Sobrevero, 1352-11, $\mathrm{s} / \mathrm{f}]$.

- Va morir el 30 de juny de 1532 [E-VAc, Almoina, Pagador dels senyals, vol. 5614, any 1532 , s/f].

- Cobraments: E-VAc, Almoina, Procura Major, vol. 5686, any 1492 , f. 18r, 52v; ibid., any 1493, f. 43v, 44r; ibid., vol. 5687, any 1503, f. 46r; ibid., Pagador dels senyals, vol. 5614, anys 1511-1532, s/f. E-VAc, not. Jaume Esteve, vol. 3686 , any 1492 , s/f, 10 de novembre de 1492; ibid., any 1493, s/f, 22 de març de 1493, 3 de juliol de 1493, 11 de novembre de 1493.

\section{Antoni Lagar}

Cantor / Catedral de València

Va ser prevere cantor de la seu de València però sembla que només durant un espai de temps inferior a l'any dins l'exercici administratiu de 1481. És possible que tinguera alguna relació amb el també cantor Francesc Lagar.

\section{Documents}

- Any administratiu 1481. Rep 12 lliures i 10 sous "per lo temps que havia servit" com a cantor [E-VAc, Almoina, Procura major, vol. 5658, any 1481 , s/f. $E$-VAc, not. Joan Esteve, vol. 3683, any 1482, s/f, 21 de gener de 1482].

\section{Francesc Lagar [Legaria]}

Cantor / Catedral de València

És possible que tinguera alguna relació amb el també cantor Antoni Lagar. El 2 de març de 1491 fou admès com a cantor a la seu de València amb salari de 3 senyals, malgrat que el canonge Roig va oposar-se per no considerar-lo per suficientment competent. Quatre mesos més tard, amb la persistent opinió contrària del mateix capitular, el capítol el va admetre a percaços, però va reduir a dos els senyals de salari. El darrer document localitzat que prova la seua presència com a cantor de la catedral, és del 13 de juny de 1493 però és possible que continuara en l'ofici.

\section{Documents}

- 2 de març de 1491. Els canonges de la seu de València l'admeten com a cantor i discuteixen sobre els senyals a atorgar-li com a salari. Acorden finalment donar-li tres senyals. [E-VAc, not. Jaume Esteve, vol. 3686, s/f].

- 25 de juny de 1491. El capítol decideix, no sense diferències, que li donen els percaços però que li lleven un senyal [E-VAc, not. Jaume Esteve, vol. 3686, s/f].

- Cobraments: E-VAc, Almoina, Procura Major, vol. 5686, any 1490 , f. 31v; ibid., any 1491,f. 31v; ibid., any 1492,f. $18 \mathrm{r}, 52 \mathrm{v}$; ibid., any 1493 , f. 43v. E-VAc, not. Jaume Esteve, vol. 3686, any 1491, s/f, 27 d'octubre de 1491; ibid., any 1492, s/f, 21 de maig de 1492, 13 d'agost de 1492, 16 d'octubre de 1492; ibid., any 1493, s/f, 26 de març de 1493 , 13 de maig de 1493, 13 de juny de 1493 .

\section{Francesc Legaria $\rightarrow$ Francesc Lagar}

\section{Jaume Martí}

Cantor / Catedral de València

Va ser cantor de la seu de València, però es desconeix el període exacte en què va exercir aquest ofici. Només se sap que ho era el 28 de març de 1496, quan el capítol va atorgarli el prorrateig d'un senyal d'un altre cantor absent. El 1505 posseïa un curiós instrument definit com un "címbol e harpa tot en una peça", una mena de claviarpa, fabricat segurament pel constructor valencià Llorenç Jorba. Amb tota seguretat després de 1511 ja no era cantor, perquè no apareix en els llibres de comptes del pagador dels senyals de l'Almoina, ni en els del procurador major.

\section{Documents}

- 28 de març de 1496. El capítol de la seu de València ordena que reba el prorrateig d'un dels senyals d'Honorat Strimundi, a causa de la seua absència $[E-V A c$, not. Jaume Esteve, vol. 3687, s/f].

- 18 de febrer de 1505. L'orguener Llorenç Jorba promet fer un "címbol e harpa tot en una peça o instrument sonant cascú per si e los dos ensems" a Antoni Fillol, canonge 
d'Oristany (Sardenya) idèntic al de Jaume Martí [E-VAc, not. Jaume Esteve, vol. 3689, s/f].

\section{Pasqual Martí}

Cantor - Mestre de cant / Catedral de València

Ja ordenat de prevere, va ingressar com a cantor de la catedral de València, probablement el juny de 1447 -aquest any administratiu va cobrar només 11 mesos- amb el salari d'un senyal. El 28 d'abril de 1451 va ser nomenat mestre de cant de la seu, un càrrec que va renovar anualment fins, almenys, el 1455. Probablement deixà de ser-ho abans del 1461, quan hi ha constància que Lluís Domínguez àlies Adzuara tenia aquest títol. La marxa de Domínguez a la cort reial com a cantor -a les acaballes del 1470 o primers mesos del 1471- va beneficiar Martí. De fet, li adjudicaren els dos senyals que tenia aquell músic i, sembla que també l'ofici de mestre de cant, ja que des d'aleshores comença novament a aparéixer en la documentació catedralícia amb aquest títol, encara que de vegades ho fa simplement com a xantre. També va fer-se càrrec, potser només durant un temps abans de maig de 1474, del treball de mestre dels fadrins diputats. Del 4 de març de 1485 data el document més tardà en què Martí apareix referit com a mestre de cant, malgrat que es tracta d'un pagament de serveis fins al desembre de 1484. No obstant, continuà a la catedral com a cantor sota el magisteri de Guillem de Podio. Fins i tot, és possible que continuara exercint la docència com a ajudant del tractadista, ja que en redactar Martí el seu testament el 10 de juny de 1493, s'anomenava a si mateix "mestre de cant a la seu". Aquest document també revel-la que era confrare de la Verge Maria i que vivia prop de la plaça de Sant Jordi. La catedral va ajudar-lo econòmicament durant la seua darrera malaltia. Va morir en sa casa el 22 de juliol del mateix any. Probablement, fou soterrat a l'església de Sant Andreu, on tenia fossa. L'inventari dels seus béns mostra un ric patrimoni consistent fonamentalment en vuit cases a la ciutat i 9 fanecades de terra a l'horta de València. També disposava d'alguns volums de teologia, litúrgia i filosofia, així com un llibre de música titulat De arte musicalis de Guido d'Arezzo.

\section{Documents}

- 28 d'abril de 1451. És nomenat per primera vegada substitut del rector de les escoles del cant de la seu de València [E-VAc, not. Jaume Monfort antic, vol. 3533, f. 127r-129v]. Va rebre idèntic nomenament anualment fins al 1455 [ibid., f. 141r-143r, 152r-154v, 160r-162r, 168r-170v].

- Any administratiu de 1470. Li donen els dos senyals de l'Almoina de la seu de València que eren de Lluís Domínguez per la marxa d'aquest [E-VAc, Almoina, Procura major, vol. 5685, any 1470, s/f].
- Any administratiu de 1474. Cobra els seus dos senyals com a xantre i mestre de les escoles del cant de la seu de València $[E-V A c$, Almoina, Procura major, vol. 5658, any 1474 , f. 24r].

- 22 de maig de 1474. És "mestre dels fadrins diputats" "qui solia tenir los diputats" [E-VAc, Almoina, Procura major, vol. 5658, any 1474 , f. 24v, 25r].

- 2 de març de 1479. Lloga una casa a València a Francesca Plana [E-VAcp, not. Bartomeu de Lloscos, vol. 21201].

- 10 de gener de 1493. és prevere beneficiat de la seu de València [E-VAc, not. Jaume Esteve, vol. 3601, f. 273r].

- 10 de juny de 1493. Darrer testament [E-VAcp, not. Alfons d'Ayerve, vol. 20514, s/f].

- 23 d'agost de 1493. Inventari dels seus béns. [E-VAcp, not. Alfons d'Ayerve, vol. 20514, s/f].

- Cobraments: E-VAc, Almoina, Procura Major, vol. 5657, any 1447 , s/f; ibid., vol. 5685, any 1471, s/f; ibid., vol. 5658, any 1472, f. 24r; ibid., any 1474, f. 24r; ibid., vol. 5685, any 1476, s/f; ibid., any $1477, \mathrm{~s} / \mathrm{f}$; ibid., any 1478 , s/f; ibid., any 1479, f. 30v; ibid., any 1480, f. 37r; ibid., vol. 5658, any 1481, s/f; ibid., any 1482, f. 32r; ibid., vol. 5685, any 1483 , f. $34 \mathrm{v}$; ibid., vol. 5658, any 1484 , f. $33 \mathrm{v}$; ibid., any 1485 , f. $33 \mathrm{v}$; ibid., any 1486 , f. $33 \mathrm{v}$; ibid., any 1487 , f. $31 \mathrm{v}$; ibid., vol. 5658, any 1488 , f. 32v; ibid., vol. 5685, any 1489, f. 31v; ibid., vol. 5686, any 1490, f. 31v; ibid., any 1491, f. 31v; ibid., any 1492, f. 18r, 52v; ibid., any 1493, f. 44r. E-VAc, not. Joan Esteve, vol. 3682, any 1478, s/f, 29 de gener de 1478, 26 de juny de 1478, 26 de setembre de 1478; ibid., any 1479, s/f, 1 d'abril de 1479, 8 de juliol de 1479, 3 de desembre de 1479; ibid., vol. 3683, any 1481, s/f, 11 d'agost de 1481; ibid., any 1482, s/f, 28 de gener de 1482,3 de juny de 1482, 13 d'agost de 1482, 12 d'octubre de 1482; ibid., any 1483, s/f, 8 de febrer de 1483, 20 de juny de 1483, 14 de novembre de 1483; ibid., any 1484, 1 de març de 1484, 30 de juny de 1484, 15 de novembre de 1484; ibid., any 1485, 4 de març de 1485, 15 de junio de 1485,26 de novembre de 1485. E-VAc, not. Jaume Esteve, vol. 3685, any 1487, s/f, 22 de febrer de 1487, 1 de juny de 1487; ibid., any 1488, s/f, 3 de juliol de 1488, 12 de novembre de 1488; ibid., any 1490 , s/f, 5 de juny de 1490 , 16 d'agost de 1490; ibid., vol. 3686, any 1491, s/f, 8 de gener de 1491, 5 de novembre de 1491; ibid., any 1492, s/f, 16 de juny de 1492, 25 d'agost de 1492, 22 de desembre de 1492; ibid., any 1493, s/f, 31 de gener de 1493, 13 de juny de 1493,15 de juny de 1493 .

Bibliografia

SANCHIS Y SIVERA (1909): 456, nota 1.

Joan Martínez $\rightarrow$ Joan Trossera àlies Martínez 


\section{Macià Mercader}

Canonge rector de les escoles del cant / Catedral de València Va ser fill del noble Joan Mercader, batlle general de València. El 1425 va obtenir un canonicat a la seu de València. Va doctorar-se en dret i amb el temps va ser ardiaca major i paborde, així com vicari general i ambaixador de la diòcesi valenciana davant la Santa Seu. Tenia una completa biblioteca i va deixar una obra sobre falconeria redactat en una estada a Nàpols. Degué ser també entès en música, ja que va ser triat pel capítol per a signar tots tres contractes coneguts d'orgueneria a la seu de València durant el segle XV $(1460,1483,1487)$, la construcció del primer dels quals, fins i tot, fou promoguda per ell mateix. A més, se sap que posseïa en el moment de la seua mort almenys un llibre de cant i un "cínbol", a més d'un monacord que sembla que li havien deixat. Va ser nomenat durant dos anys administratius (1486, 1489) canonge rector de les escoles del cant de la seu valenciana. Va morir a València el 26 de juny de 1489 .

\section{Documents}

- 8 de maig de 1425. Pren possessió d'una canongia a la seu de València [E-VAc, not. Joan Esteve, vol. 3596, f. 2r].

- 12 de maig de 1460. Va proposar la construcció d'un orgue major a la seu i va ser comissionat pel capítol per a signar un contracte amb l'orguener Pere Ponç amb aquesta finalitat [E-VAc, not. Joan Esteve, vol. 3679, s/f].

- 5 de febrer de 1483. Va ser comissionat pel capítol per a signar un contracte amb Marturià Prats per a construir un orgue a la seu valenciana $[E-V A c$, not. Joan Esteve, vol. $3683, \mathrm{~s} / \mathrm{f}]$.

- 26 d'abril de 1486. És triat pel capítol de València com a rector de les escoles del cant de la seu [E-VAc, not. Joan Esteve, vol. 3596, f. 10v-12v].

- 28 de juliol de 1486. És doctor en decrets, ardiaca major i paborde de la seu valenciana, així com vicari general de la diòcesi [E-VAc, not. Joan Esteve, vol. 3596, f. $47 \mathrm{v}-48 \mathrm{r}]$.

- 7 de setembre de 1487. Va ser comissionat pel capítol de la seu de València per a signar el contracte amb l'orguener Joan Spindelnoguere per a reformar l'orgue major [E-VAc, not. Jaume Esteve, vol. 3685, s/f].

- 27 d'abril de 1489. És triat pel capítol de València com a rector de les escoles del cant de la seu $[E-V A c$, not. Jaume Esteve, vol. 3605, f. 111r-111v, 115r].

Bibliografia

PONS ALÓS i CÁRCEL ORTÍ, 35:2 (Barcelona, 2005): 940. FERRER GIMENO, 4 (1987-1988): 441-469. MELCHOR FENOLLOSA (2014). VILLANUEVA SERRANO, 30 (Saragossa, 2014a): 57-60; 43 (Laaber, 2014b): 11-12.

\section{Guillem Molins àlies de Podio}

Mestre de cant - Mestre de capella - Cantor - Cabiscol mitjà / Catedral de Barcelona - Capella de Joan II d'Aragó Capella de la reina Joana - Catedral de Girona- Catedral de València

L'abril de 1445 era escolà de la catedral de Barcelona. Del 12 de març al 16 d'abril de 1446 va prendre tots els ordes eclesiàstics, d'acòlit a prevere, la qual cosa indica que probablement va nàixer abans del 1421. El mateix mes d'abril de 1446 figura per primera vegada en la documentació localitzada amb el títol de mestre de cant de la mateixa seu. No obstant això, sembla que en principi no va gaudir de tots els drets del càrrec, atès que el veterà Gabriel Claret va continuar rebent la taxa annexa al magisteri que pagaven els nous canonges, fins al 24 de març de 1451, data a partir de la qual comença a cobrar-les Guillem de Podio. Es coneixen alguns detalls de la seua activitat en aquest càrrec al capdavant dels infants cantors, els quals cantaven lliçons en oficis de matines, o motets en els oficis de completes els dissabtes de Quaresma en la capella de Santa Eulàlia. Així mateix, consta que estava al capdavant d'un grup de músics que cantaven davant de la custòdia en la processó del Corpus Christi. Fora de l'activitat catedralícia, se sap que aportà la música a la missa solemne d'inauguració de la capella de la llotja de Barcelona el 23 de novembre de 1452 juntament amb un grup de deixebles i, dos anys més tard, participà en un ofici de completes al mateix lloc. En aquesta etapa va rebre del bisbat barceloní, si més no, la procuradoria del benefici catedralici de Sant Andreu i la curadoria de la vicaria de l'església del monestir de les Penedides de Barcelona, que li reportarien rendes no consolidables. Va exercir el magisteri de la seu barcelonesa, almenys, fins al 30 de maig de 1458. Posteriorment ingresà com a cantor a la capella reial de Joan II de la qual, amb seguretat, ja formava part el 22 de febrer de 1459. És possible que, al mateix temps, també accedira al càrrec de mestre de la petita capella de la reina Joana Enríquez, que ja posseïa amb seguretat el 2 de gener de 1461 i que, potser, li atorgava una posició, en la pràctica, de segon mestre de la capella del rei. Durant aquests primers anys en la cort se sap que es feia càrrec dels infants cantors i, segurament, de la corresponent formació musical. Podio formava part del selecte grup de vuit cantors que cobraven de l'Escrivania i fou un dels més agraciats en la política beneficial del monarca, al temps que gaudí de fruits i rendes requisades a rebels catalans. El maig de 1467 necessità, i rebé, un salconduit del rei per a transportar béns que tenia a Barcelona fins a Tarragona o un altre lloc d'obediència reial. L'1 de desembre de 1467 va obtenir una plaça de prevere de capítol a la catedral de Girona. Malgrat això, sembla que va seguir el rei mentre va durar la guerra catalana, encara 
que estava al corrent dels assumptes de la catedral gironina. El 1470 no rebia les rendes que li corresponien en aquesta catedral i fou privat dels seus béns a Girona, en un moment en què la ciutat s'havia unit a la rebel-lió, per la qual cosa fou compensat pel rei. Després de la ràpida recuperació de la ciutat per Joan II, Guillem de Podio començà a residir a la catedral gironina, la qual es pot constatar fefaentment des del 8 de novembre de 1471. En la mateixa època va rebre un canonicat en la colegiata de Sant Feliu de la mateixa ciutat, i les rendes segrestades a un francès. El març de 1473 de l'any següent fou enviat a Perpinyà en representació del capítol gironí, on es celebraven corts catalanes. Fins a les acaballes de 1474 va complir aquesta missió, també a Barcelona, durant períodes més o menys llargs de temps, no sense conflicte amb el capítol, que no sempre atenia les seues pretensions salarials com a contraprestació a aquest treball. Podio aprofitava l'estada a la cort per a servir en la capella i per a gestionar els seus beneficis eclesiàstics. El gener de 1474 rebia la pabordia de Tordera de la mateixa col-legiata tot i que, abans que acabara el mes, renuncià a ella per a permutar-la. Uns mesos més tard sembla que també pretenia permutar la seua plaça de prevere de capítol a Girona, però en aquest moment no arribà a fer-ho. Després de la tornada definitiva del músic a Girona des de les corts, Podio es dedicà més a les tasques administratives i de gestió econòmica a la catedral. De fet, fou capellaner i auditor de comptes, així com síndic per a contractar un segur o per a tractar sobre la creació d'un estudi general a Girona. També ocupava el seu temps en assumptes purament eclesiàstics, como ara la celebració de misses d'aniversaris. En el camp musical, des de la seua posició capitular exercia la lloctinència del cabiscol mitjà amb competències per a assignar els cants. En sa absència, el maig de 1478, la catedral gironina va nomenar dos substituts per a aquesta funció. També fou designat per a tractar sobre la creació d'un col-legi de vuit infants regit per un mestre de cant i per a reactivar, després de la guerra, un contracte amb un escrivà de llibres de cor. Les seues absències de la cort motivaren que foren redistribuïdes les seues quitacions en diverses ocasions. Del 1475 al 1478 va fer alguns viatges a la cort. Entre les acaballes del setembre i el començament de l'octubre de 1477, Podio permutà el seu canonicat en Sant Feliu de Girona amb un benefici a l'altar de Sant Jaume a la catedral de València, que pertanyia al seu company Bartomeu Segrera. Després de la mort de Joan II, Podio es traslladà a València, i a la catedral d'aquesta ciutat va residir durant la resta dels seus dies. El 30 de desembre de 1479 ja es trobava a la capital valenciana, quan acceptà un deixeble d'11 anys anomenat Ferran Mancebo al qual havia d'ensenyar les primeres lletres y llengua llatina, així com cant pla i d'orgue, a canvi del servei domèstic. En els primers mesos d'estada va permutar la seua plaça de prevere de capítol de Girona amb una capellania a Sant Vicenç de Maià la qual, immediatament intercanvià amb la vicaria perpètua de l'església de Santa Maria de La Puebla de Alfindén que també posseïa Bartomeu Segrera, amb la col-laboració de diversos antics companys de la capella reial, que actuaren com a procuradors en diverses ciutats. Pot constatar-se que el 16 de març de 1485 ja era mestre de les escoles de cant catedralícies, un càrrec que renovà anualment fins la seua mort, a excepció del 1494 i del 1496. Va estar prop de les obres d'orgueneria que es desenvolupaven en la ciutat, actuant com a expert examinador. Ferran el Catòlic li va concedir una renda vitalícia de 30 lliures anuals el 1495. Va morir a la capital valenciana l'1 de novembre de 1500. La seua activitat com a teòric musical hui coneguda procedeix dels seus darrers anys. El 1495 va publicar a València el complet tractat Ars musicorum o Commentariorum musices i posteriorment va escriure Enchiridion de principiis musice discipline contra negantes illa et destruentes, que es conserva en el manuscrit $I-B c$, A.71, p. 134-190. També es conserven un parell d'escrits de menor entitat, en castellà i català, vinculats textualment al llibre setè de l'imprès $[I-B C$, A.71, p. 191-207; $E-B c$, ms. 1325, f. 14r-19r] i un altre en castellà $[I-B c, \mathrm{~A} .71, \mathrm{p} .266-276]$ que manté una relació més difusa amb la obra de l'autor. En l'inventari i encant d'un mestre dels diputats de la seu de València (1505) hi havia quatre passions notades relacionades amb Guillem de Podio.

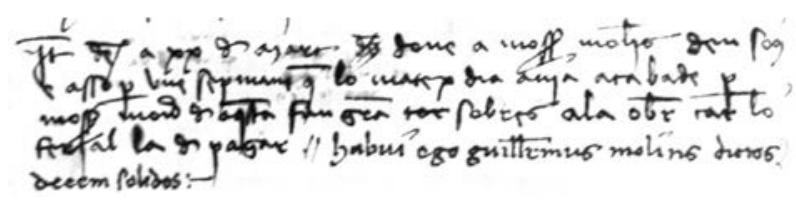

[E-G, Llibres d'Obra, anys 1472-1478, f. 152v]

\section{Documents}

- Abril de 1445. Rep un pagament, com a escolà de la seu de Barcelona, per llevar les estores $[E-B c$, sagristia, sagristia en general, anys 1443-1445, f. 83v].

- 12 de març de 1446. Pren a Barcelona les ordes d'acòlit i de sotsdiaca. En la llista d'acòlits ordenats figura "Guillermus Molins, clericus Barchinone" [ADB, Registra Ordinatorum, vol. 10, f. 105r, 105v].

- 2 d'abril de 1446. Pren a Barcelona l'orde de diaca [ADB, Registra Ordinatorum, vol. 10, f. 110r].

- 16 d'abril de 1446. Pren a Barcelona l'orde de prevere. [ADB, Registra Ordinatorum, vol. 10, f. 113r].

- Abril de 1446. Es mestre del cant de la catedral de Barcelona [E-BC, catedral, sagristia, sagristia en general 1445-1447, f. $32 \mathrm{r}]$. 
- 16 de juny de 1448. Cobra 8 lliures i 6 sous com a procurador del benefici de Sant Andreu a la seu de Barcelona [E$B c$, capítol, caritat o mensa capitular, aniversaris, llibres d'administració, any 1448 , f. 17v].

- 24 de maig de 1449. Rep la curadoria de la vicaria de l'església del monestir de les Penedides de Barcelona [ADB, Registra Gratiarum, vol. 35, f. 79v].

- 24 de març de 1451. Comença a cobrar dels nous canonges les quantitats que corresponien al mestre de cant $[E-B c$, capítol, dignitats i oficis, notaria, not. Joan Ginebret, vol. 837, f. 169r; ibid., vol. 839, f. 8v].

- 23 de novembre de 1452. Actua en la missa d'inauguració de la nova capella construïda en la llotja de Barcelona, amb un grup de deixebles que aportaren el cant [AAB, Consolat del Mar, R-2457, f. 44v].

- Any 1454. Participa en un ofici de completes a la capella de la llotja de Barcelona [AAB, Consolat del Mar, R-2457, f. 25r (2a numeració)].

- 30 de maig de 1458. Rep 8 lliures i 5 sous de l'administració municipal barcelonesa per cantar amb altres companys en la processó del Corpus Christi [AHPB, not. Miquel Ferran, lleg. 4, manual de l'any 1458].

- 22 de febrer de 1459. Acudeix juntament amb un gran nombre de capellans dels reis, davant el notari valencià Mateu Cirera per a nomenar tres procuradors per a gestionar els seus interessos eclesiàstics a Roma [E-VAcp, not. Mateu Cirera, vol. 21868, s/f].

- 10 d'octubre de 1459. Nomena procurador per a renunciar a la rectoria de Sant Llorenç de Morunys, simplement o per motiu de permuta [AHPB, not. Bartomeu Costa (major), vol. 175/13, s/f].

- Anys 1460-1461. S'encarrega de la cura dels infants cantors de la capella reial [E-VAar, Mestre Racional, vol. 9815, f. 176v, 5 de maig de 1460; ibid., vol. 8804, f. 97r, gener de 1461; ibid., vol. 9815, f. 310r, març de 1461].

- 2 de gener de 1461. Joan II proposa Guillem de Podio, capellà i cantor reial, així com mestre de la capella de la reina, davant el papa per a la rectoria de la parròquia de Sant Andreu de València. Envia també sengles cartes al cardenal viceconseller del papa i al seu conseller i ambaixador a la cort romana [E-Bac, Cancelleria Reial, reg. 3374, f. 122v; ibid., f. 122v-123r; ibid., f. 123r-123v].

- 14 de gener de 1461. Joan II retira la petició de concesió, en favor del músic, de la rectoria de Sant Andreu de València, puix un altre capellà seu, anomenat Joan de Xipre, ja havia pres possessió de la rectoria $[E-B a c$, Cancelleria Reial, reg. 3374, f. 130v-131r; ibid., f. 131r-131v].

- 5 d'agost de 1463. Joan II ordena que es lliuren a Podio una part dels fruits, drets, rendes i emoluments de la rectoria de Torres-Torres i de certs beneficis a Mosqueruela, requisats per manament reial a dos rebels [E-VAar, Reial Cancelleria, reg. 401, f. 67r].

- 12 d'octubre de 1464. Joan II ordena que es lliuren a Podio tots els fruits, rendes, drets i emoluments de la rectoria d'Alcover [E-Bac, Cancelleria Reial, reg. 3378, f. $145 \mathrm{r}-145 \mathrm{v}]$.

- 15 de març de 1465. Joan II demana al vicari general del bisbe de Mallorca la provisió en favor de Podio d'un dels tres beneficis de la diòcesi que pertanyien a dos preveres insurrectes [E-Bac, Cancelleria Reial, reg. 3426, f. 130v]. $\mathrm{El}$ rei ordena al seu procurador fiscal a Mallorca que vetlle pel compliment de la seua petició [ibid., f. 130v-131r].

- 29 d'abril de 1465. Joan II demana al vicari general de Mallorca que siga dictada sentència al rebel Pere Esteve i li indica que, en cas de ser culpable, s'atorguen a Podio la rectoria de Sineu i els altres beneficis d'aquell [E-Bac, Cancelleria Reial, f. 138v]. El rei també demana el seguiment de l'assumpte al seu procurador fiscal [ibid., f. $138 \mathrm{v}-139 \mathrm{r}]$.

- 1 de maig de 1466. Joan II sol-licita per al seu cantor, als bisbes de Girona i Barcelona, un o dos beneficis que estiguen vacants $[E-B a c$, Cancelleria Reial, reg. 3446, f. $88 \mathrm{r}-88 \mathrm{v}]$

- 21 de maig de 1467. Joan II atorga a Podio un salconduit per a transportar els béns mobles i les robes que tenia a la insurrecta Barcelona, on segurament encara tenia casa, fins a Tarragona o a un altre lloc d'obediència reial $[E-B a c$, Cancelleria Reial, reg. 3381, f. 133r-133v].

- 12 de juliol de 1467. Joan II fa un requeriment al bisbe de Tortosa perquè atorgue a Podio un benefici a la catedral, del qual havia sigut desposseït el rebel Pere Vicent [E-Bac, Cancelleria Reial, reg. 3448, f. 4r].

- 1 de desembre de 1467. Consta la possessió de plaça de prevere de capítol de la seu de Girona, mercés a una gràcia d'expectativa, per part de "Guillermus Molins àlias de Podio" $[E-G$, Episcopologi. Sèrie dels prebendats, vol. 105 , f. 291v].

- 20 de febrer de 1468. Joan II ordena al procurador i collector de les rendes que el capítol de Girona rep a Mallorca, que anul·le l'efecte d'una carta anterior, després d'escoltar certa informació de Pere Vinyoles i Guillem Molins, capellans reials i també membres capitulars [E-Bac, Cancelleria Reial, reg. 3429, f. 133v-134r].

- 11 de febrer de 1470. Joan II atorga a Podio 1.000 sous barcelonesos anuals mentre es mantinga la rebel-lió a Girona, en compensació a les pèrdues sofrides en les seues rendes i béns [E-Bac, Cancelleria Reial, reg. 3427, f. 138v-139v]. El 31 d'octubre de 1471 el monarca insistia al virrei de Mallorca sobre l'assumpte, ja que no s'estava complint [ibid., reg. 3430, f. 51v]. 
- 25 d'octubre de 1471. El capítol gironí dispensa Podio de l'estatut catedralici que prohibeix la possessió simultània d'una plaça de prevere capitular a la seu i d'un canonicat a la col-legiata de Sant Feliu [ADG, Cúria i vicariat general, Beneficial, Col-lacions de beneficis, vol. 46(23) [D/199], f. $107 \mathrm{v}]$.

- 8 de novembre de 1471. Assisteix com a prevere de capítol a la primera reunió capitular de la seu gironina de què es té constància [ $E-G$, Actes Capitulars, vol. 4, f. 142r].

- 2 de desembre de 1471. Joan II concedeix temporalment a Podio totes les rendes segrestrades pertanyents a l'abat de la col-legiata de Sant Feliu de Girona, que fins aleshores posseïa un francès anomenat Claudi $[E-B a c$, Cancelleria Reial, reg. 3452, f. 49r-49v].

- 13 de desembre de 1471. És elegit per a formar part d'una comissió que ha de tractar sobre la creació d'un col·legi catedralici amb vuit infants, dirigit per un mestre de cant [E-G, Resolutiones, vol. 4, f. 150v-151v].

- 30 de desembre de 1471. És designat procurador capitular davant la cort reial [ $E-G$, Resolutiones, vol.4,f. 151r-151v]. - 30 de desembre de 1471. Es llig a la seu gironina una carta de Podio enviada des de la cort reial a Barcelona $[E-G$, Resolutiones, vol. 4, f. 151r-151v].

- 30 de desembre de 1471. Podio lliura al canonge i secretari capitular un escrit de Jeroni d'Erfurt en el qual es formulava una predicció sobre un eclipsi solar que tindria lloc el setembre de 1472 [ $E$ - $G$, Resolutiones, vol. 4, f. 152 r].

- 24 de gener de 1473. Es rep a la seu gironina una carta informativa enviada per Podio des de Barcelona amb novetats sobre assumptes econòmics del capítol $[E-G$, Resolutiones, vol. 5, f. 5r].

- 28 de març de 1473. Podio signa, amb altres tres membres capitulars, un contracte amb un escrivà de llibres de cor per a la continuació d'un treball acordat abans de la guerra catalana [E-G, Resolutiones, vol. 4, f. 226r].

- 29 de març de 1473. Rep, juntament amb el canonge Andreu Alfonsello, el nomenament capitular per a acudir com a síndic a Perpinyà, on començaven les corts, sense assignació de salari específic [E-G, Resolutiones, vol. 4, f. $225 \mathrm{v}]$. El dia següent fou registrada notarialment aquesta determinació capitular [ADG, Llibres notarials, vol. G/68, f. 239r-239v].

- 6 d'abril de 1473. El capítol gironí li comunica una sèrie d'instruccions per al desenvolupament de les seues funcions en les corts [ADG, Llibres notarials, vol. G/68, f. 226r].

- 4 de novembre de 1473. El capítol gironí l'envia a Barcelona, on s'havien traslladat les sessions de corts. Li concedeix una retribució especial de 4 sous diaris mentre que no hi anara també algun canonge de la seu $[E-G$, Resolutiones, vol. 4, f. 266r-266v].

- 9 de gener de 1474. Es llig a la catedral de Girona una carta petitòria del salari compromès, enviada per Podio, $\mathrm{i}$ el capítol decideix enviar-li 10 lliures per aquest concepte [E-G, Resolutiones, vol. 5, f. 6v].

- 18 de gener de 1474. Rep la pabordia de Tordera a la col-legiata de Sant Feliu de Girona [AHPB, not. Dalmau Ginebret, vol. 219/54, s/f].

- 26 de gener de 1474. Podio permuta la pabordia de Tordera a la col-legiata de Sant Feliu amb el benefici diaconil de l'església de Santa Eulàlia del palau de l'Ardiaca a Girona [ADG, cúria i vicariat general, beneficial, Col-lacions de beneficis, vol. 46 (23) [D/199], f. 178r].

- 22 de febrer de 1474. El capítol li fa un altre lliurament més, segurament de 34 sous [ $E-G$, Resolutiones, vol. 5, f. $11 \mathrm{v}]$.

- 13 de maig de 1474. Es lligen dues cartes de Podio en el capítol gironí. En una d'elles informa que les corts havien oferit 4.000 lliures al rei a canvi de la restitució dels béns confiscats durant la guerra. En l'altra, s'interessa pel seu salari quan el sobirà s'absente de Barcelona $\mathrm{i}$, per tant, no puga cobrar la seua quitació de capellá reial per no seguir el monarca. El capítol contesta que no li atorgaria remuneracions periòdiques sinó arbitràries, sense precisar la quantitat $[E-G$, Resolutiones, vol. 5, f. $27 \mathrm{v}-28 \mathrm{r}]$.

- 28 de juny de 1474. Joan II el presenta al segon benefici de Sant Blai al claustre de la seu de Barcelona [E-Bac, Cancelleria Reial, reg. 3388, f. 100r-100v]. El dia següent es féu la col-lació [ADB, Col-lacions, vol. 72, f. 115r-116v]. - 12 de juliol de 1474. Andreu Bertrán, beneficiat a la seu gironina, demana al capítol que impedisca a Podio la permuta de la seua plaça de prevere de capítol, ja que encara no havia satisfet els drets acostumats de capa, fàbrica i servei des que havia pres possessió, els quals havien sigut avalats per Bertrán i altres capellans [ADG, Cúria i vicariat general, Beneficial, Manuals de col-lacions, vol. 46 (23) [D/199], f. 200r].

- 14 de setembre de 1474. Compareix davant el capítol gironí per a explicar l'evolució de les corts i per a reclamar l'ajuda econòmica promesa. El capítol li concedeix puntualment 10 lliures [E-G, Resolutiones, vol. 5, f. 40r-40v].

- 12 d'octubre de 1474. El bisbe de Girona insta al capítol a enviar de nou a Podio a corts per a resoldre una sèrie de greuges. Li és oferit un salari diari de 5 sous amb l'anticipació d'un mes [E-G, Resolutiones, vol. 5, f. 41v]. - 17 de novembre de 1474. A la catedral de Girona és llegida una carta seua enviada des de les corts a Barcelona. El capítol nomena un tercer síndic, que s'uneix a Podio i Alfonsello, retira a Podio el salari específic i li dóna llibertat 
per tornar a Girona si no le satisfà $[E-G$, Resolutiones, vol. 5 , f. $42 \mathrm{v}-43 \mathrm{r}]$.

- 28 de desembre de 1474. Exerceix de lloctinent del cabiscol mitjà de la catedral de Girona, responsable de assignar els cants [ $E-G$, Resolutiones, vol. 5, f. 54v].

- 6 de maig de 1475. És nomenat capellaner pel capítol de Girona durant un bienni [ $E-G$, Resolutiones, vol. 5, f. 79r].

- 6 de juny de 1475. Joan II redistribueix les quitacions de Podio de la terça del gener a l'abril de 1475 , per absència de la cort [E-Bac, Cancelleria Reial, reg. 3420, f. 82v-83r].

- 20 d'octubre de 1475. Podio presenta al clergue Guillem Noguera per al benefici del Corpus Christi de la seu gironina [ADG, Cúria i vicariat general, Beneficial, Col·lacions de beneficis, vol. 46(23) [D/199], f. 268r-268v].

- 12 de gener de 1476. Joan II redistribueix les quitacions de Podio de la terça de setembre a desembre de 1475, per absència de la cort $[E-B a c$, Cancelleria Reial, reg. 3418, f. $165 \mathrm{r}-165 \mathrm{v}]$.

- 8 de maig de 1476. Rep l'encàrrec, juntament amb el canonge Andreu Alfonsello, de concertar un segur per a la pabordia de maig de la seu gironina $[E-G$, Resolutiones, vol. 5 , f. $144 \mathrm{v}]$.

- 13 de maig de 1476. És designat, juntament amb el també prevere de capítol Antoni Corbera, per a examinar els comptes de les capellanies i organitzar les oportunes distribucions [ $E-G$, Resolutiones, vol. 5, f. 148r].

- 23 de maig de 1476. Joan II redistribueix les quitacions de Podio de la terça de gener a abril de 1476, per absència de la cort [E-Bac, Cancelleria Reial, reg. 3418, f. 170r-170v].

- 3 de setembre de 1476. Podio llig davant el capítol de Girona una carta del síndic a corts $[E-G$, Resolutiones, vol. 5, f. 110r-110v, 165v].

- 3 d'abril de 1477. Podio manifesta la conformitat per a la col-lació del benefici del Corpus Christi de la catedral de Girona al clergue Martí Bauler [ADG, Cúria i vicariat general, Beneficial, Col-lacions de beneficis, vol. 46(23) [D/199], f. 48r].

- 2 de maig de 1477. Podio exposa al capítol que la majoria de les capellanies no s'han arrendat per manca d'ofertes [E-G, Resolutiones, vol. 5, f. 198v].

- 6 de maig de 1477. És elegit auditor de comptes de la catedral gironina juntament amb el canonge Pere de Tarrades [E-G, Resolutiones, vol. 5, f. 200v-201r].

- 7 de maig de 1477.És elegit per a formar part d'una comissió de quatre membres que ha de tractar sobre la creació d'un estudi general a Girona amb altres representants de l'administració municipal $[E-G$, Resolutiones, vol. 5, f. 201v].

- 1 de setembre de 1477. Nomena a Barcelona Jaume Castelló com a procurador per a gestionar en el seu nom les permutes de la canongia de la col-legiata de Sant Feliu de Girona i el segon benefici de Sant Blai de la seu de Barcelona, amb unes altres de Bartomeu Segrera o de qualsevol altre eclesiàstic [AHPB, Not. Antoni Palomeres, vol. 207/12, s/f].

- 1 de setembre de 1477. Podio i Bartomeu Segrera es comprometen a no permutar els seus beneficis amb altres persones i a no revocar les procuracions atorgades [AHPB, Not. Antoni Palomeres, vol. 207/12, s/f].

- 9 de setembre de 1477 . Nomena com a procurador per a realitzar gestions beneficials a València el notari Joan Fabra àlies Benet [AHPB, Not. Antoni Palomeres, vol. 207/12, s/f].

- 9 de setembre de 1477. Joan II li autoritza la permuta del benefici segon de Sant Blai a la seu de Barcelona [E-Bac, Cancelleria Reial, reg. 3391, f. 54v-55r].

- 15 de setembre de 1477. Designa Antoni Ferran, beneficiat a la seu de Girona, i Pere Bartomeu, hospitaler en Sant Pere de Galligants com a procuradors per a les gestions beneficials a Girona [AHPB, Not. Antoni Palomeres, vol. 207/12, s/f].

- 3 d'octubre de 1477. Renuncia al benefici de Santa Maria, Jaume i Salomé de la catedral de València davant el vicari general de València [ADV, Col-lacions de beneficis, vol. 140/002, f. 208r].

- 24 d'octubre de 1477. Renuncia al benefici segon de Sant Blai a la catedral de Barcelona [ADB, Col·lacions, vol. 73, f. $177 \mathrm{v}]$.

- 20 de març de 1478. Reconeix a l'administrador de l'Obra de la catedral de Girona el cobrament de 10 sous per una semana de serveis realitzats en substitució d'un altre prevere [ $E-G$, Llibres d'Obra, años 1472-1478, f. 152v].

- 6 de maig de 1478. A causa de la seua absència, el capítol de Girona nomena dos substituts per a ordenar la música [E-G, Resolutiones, vol. 5, f. 232v].

- 30 de juny de 1478 . Asisteix a una reunió capitular de la catedral de Girona [ADG, Cúria i vicariat general, Beneficial, Col-lació de beneficis, vol. 49(26) [D/202], f. $112 \mathrm{r}]$.

- 23 de novembre de 1478. A causa de l'absència de Podio, Joan II concedeix les quitacions que li corresponien percebre a partir del 24 de juny de 1478 al cantor Joan Membrado [E-Bac, Cancelleria Reial, reg. 3420, f. 176r-176v].

- 24 de desembre de 1478. El seu nom està inclòs en un albarà de l'escrivà de ració del rei per a cobrar 40 sous de la Tresoreria reial en concepte de quitacions, que es féu efectiu el mateix mes [E-VAar, Mestre racional, vol. 8831, f. 136r-137r].

- 30 de desembre de 1479. Podio signa un contracte d'aprenentatge pel qual Ferran Mancebo, infant d'uns onze 
anys d'edat i fill d'un sastre de València, el servirà durant cinc anys a la seua casa valenciana. A canvi, el músic li ensenyarà la lectura, l'escriptura, la gramàtica [llatina], el cant pla i el cant d'orgue, a més de proporcionar-li la manutenció i la roba [E-VAcp, not. Bartomeu de Carries, vol. 20434, s/f].

- 21 de març de 1480. Nomena procuradors per a gestionar permutes a Saragossa els seus antics companys Daniel Genovés i Pedro Pifán, així com el canonge Jofre Gostant [E-VAcp, not. Bartomeu Lloscos, vol. 21204, s/f].

- 21 de març de 1480 . Nomena com a procuradors per a gestionar permutes a Girona el seu antic company Jaume Castelló i Francí Febrer àlies Santacana, prevere de la catedral de Barcelona [E-VAcp, not. Bartomeu de Lloscos, vol. 21204, s/f].

- 21 de març de 1480. Nomena com a procuradors el seu antic company Bartomeu Segrera i un clergue de Vic anomenat Antoni Grau per a signar una concòrdia de permutes a Barcelona [E-VAcp, not. Bartomeu de Lloscos, vol. 21204, s/f].

- 1 de maig de 1480. Podio i Rafael Pou renuncien a la plaça de prevere de capítol de Girona i a la capellania de Sant Vicenç de Maià, respectivament, davant el bisbe de Barcelona, per a permutar-les i es formalitza l'intercanvi, prèvia l'autorització del bisbe i vicari general de Girona [ADB, Col-lacions, vol. 75, f. 1r-2v].

- 5 de maig de 1480. Podio permuta la capellania de Sant Vicenç de Maià per la vicaria perpètua de l'església de Santa Maria de La Puebla de Alfindén, diòcesi de Saragossa, amb Bartomeu Segrera [ADG, Cúria i vicariat general, Beneficial, Col-lació de beneficis, vol. 49(26) [D/202], f. 195v-196r].

- 17 de juny de 1480 . Nomena com a procuradors Francisco Boyons i Sancho Marça, mercaders de Saragossa, per a cobrar en el seu nom qualssevol rendes pertanyents al benefici de l'església de Santa Engràcia [E-VAcp, not. Bartomeu de Lloscos, vol. 21204, s/f].

- 10 de gener de 1481. Nomena el notari valencià Alfonso Ayerve com a procurador per a cobrar [E-VAcp, not. Andreu Cirera, vol. 20621, s/f].

- 30 de gener de 1481. Reconeix que Martí Sparça, ciutadà de València, li ha pagat en diverses ocasions quantitats cobrades de diferents deutors com a procurador seu fins l'any 1480 inclòs. Allibera el mateix procurador dels pagaments pendents [E-VAcp, not. Ausiàs Sans, vol. 2060, s/f].

- 29 d'octubre de 1483. Nomena com a procuradors seus Daniel Genovés, prevere racioner de La Seo de Saragossa, i Gil de Miranda, ciutadà de Saragossa, perquè en el seu nom cobren qualssevol rendes de la vicaria perpètua de $\mathrm{La}$ Puebla de Alfindén [E-VAcp, not. Bartomeu de Lloscos, vol. 20205, s/f].
- 2 de juliol de 1484. Rep 60 sous del jurista Joan Alegret, possiblement d'un censal [E-VAcp, not. Bartomeu Bodí, vol. 14401, s/f].

- 2 de juliol de 1484. Alfons d'Ayerve, notari de València, com a procurador de Guillem Molins de Podio, reconeix que Joan Alegret, doctor en dret, li ha pagat 60 sous, quantitat que paga anualment al benefici de Sant Jaume de la catedral de València [E-VAcp, not. Bartomeu Bodí, vol. $14401, \mathrm{~s} / \mathrm{f}]$.

- 16 de març de 1485. El capítol de València li atorga un senyal de l'administració de l'Almoina (7 lliures i 10 sous anuals) en qualitat de mestre de les escoles del cant $[E-V A c$, not. Joan Esteve, vol. 3683, s/f].

- 10 de juny de 1485 . Revoca qualsevol procuració anterior i nomena Constanza de Bolas, vídua de Saragossa, procuradora per a cobrar en el seu nom qualssevol quantitats degudes per la seua capellania reial a l'església de Sant Jeroni i Santa Engràcia de Saragossa i de la vicaria perpètua a l'església de La Puebla de Alfindén [E-VAcp, not. Bartomeu de Lloscos, vol. 21207, s/f].

- 7 de setembre de 1487. És testimoni en el contracte de reforma de l'orgue major de la catedral de València $[E-V A c$, not. Jaume Esteve, vol. 3685, s/f].

- 15 de juliol de 1489. És designat examinador per al nou orgue que es contracta per a la parròquia de Sant Tomàs de València [E-VAar, not. Pere Joan Zabrugada, vol. 3064, $\mathrm{s} / \mathrm{f}]$.

- Any 1490. Paga un terç de les rendes del seu benefici a la catedral de València per l'absència del 19 de juny al 15 d'octubre a causa de la pesta $[E-V A c$, Terç de benifets d'absents, vol 4041, año 1490, s/f].

- 4 de novembre de 1491. Ferran el Catòlic ordena a l'encarregat de la marmessoria de Joan II que, de les pecúnies d'aquesta administració, pague a Guillem Molins de Podio els 3.560 sous barcelonesos pendents de pagament de les quitacions ordinàries com a capellà del seu pare [E-Bac, Cancelleria Reial, reg. 3572, f. 26v-27r].

- 21 d'octubre de 1492. És un dels tres "grans artistes en l'art de música" que examinaren el nou orgue de la parròquia de Sant Joan del Mercat de València [E-VAcp, not. Bartomeu de Carries, vol. 20444, s/f]. Agraïsc a Jaume Richart l'advertència sobre la existència d'aquest document.

- 4 de maig de 1493. Ferran el Catòlic ordena al seu escrivà Antoni Tomàs que pague immediatament a Podio les pensions que li corresponen d'aquesta escrivania pel seu benefici a l'església de Santa Engràcia de Saragosa, les quals no havia cobrat [E-Bac, Cancelleria Reial, reg. 3571, f. $74 \mathrm{v}]$.

- 3 d'abril de 1495. Ferran el Catòlico li concedeix una renda vitalícia de 30 lliures valencianes anuals per la pèrdua del 
benefici de Santa Engràcia de Saragossa, de la qual s'ha de fer càrrec la Batllia General del regne de València [E-VAar, Reial Cancelleria, reg. 309, f. 291v-292v]. El mateix dia comunicava la decisió al batlle general [E-VAar, Reial Cancelleria, reg. 596, f. 170v-171r].

- 10 de desembre de 1496. Nomena un mercader barcelonès anomenat Bernat Oliver com a procurador per al cobrament de certa quantitat a Cerdenya [E-VAar, not. Jaume Salvador, vol. 2696, s/f].

- 10 de desembre de 1496. Ferran el Catòlic decideix que siga el tresorer general o els seus lloctinents, i no el batlle general, els qui s'encarreguen de pagar la pensió anual de 30 lliures [E-Bac, Cancelleria Reial, reg. 3553, f. 157r-158r].

- 13 de desembre de 1496. Ferran el Catòlic comunica al batllle general en el regne de València que ha commutat la renda vitalícia de 30 lliures valencianes anuals atorgada a Guillem Molins, de la Batllia General de València a la Tresoreria General [E-VAar, Batllia General, Lletres i privilegis, vol. 1161, f. 343v].

- 1 de novembre de 1500. El pagador dels senyals de l'Almoina de la catedral de València deixa constància de la mort de Guillem de Podio [E-VAc, not. Lluís Esteve, vol. 3631 , fullet solt].

- 1 de novembre de 1500. El vicari general de València confereix el benefici en l'altar de Sant Jaume de la catedral fundat pel rei Jaume I a Gaspar Carles de Cabanyelles, per mort de l'anterior posseïdor Guillem de Podio [ADV, Manuale, sign. 337/001, s/f].

- 20 de setembre de 1505. En l'inventari/encant dels béns de Joan Montesino, domer i mestre dels diputats de la seu de València hi ha "quatre passis notats e ligats cascú per sí ab cubertes de pergamí" [...] "de mestre Podio" [E-VAcp, not. Guillem Ramon Tovia, vol. 26408, s/f]

- Asistències a capítols a la catedral de Girona: E-G, Resolutiones, vol. 4, f. 142r, 143r, 147v, 158r, 177v, 186r, 187r, 192r, 195v, 222r, 225r, 248r, 251v, 266r, 266v; ibid., vol. 5, f. 41v, 57r, 62r, 66v, 79r, 80r, 81v, 83v, 107r, 114v, $115 \mathrm{v}, 133 \mathrm{v}, 137 \mathrm{v}, 144 \mathrm{v}, 148 \mathrm{r}, 160 \mathrm{r}, 164 \mathrm{v}, 165 \mathrm{v}, 168 \mathrm{v}, 176 \mathrm{r}$, 179r, 180r, 192r, 192v, 194v, 198v, 200v-201r, 201v, 202r, $245 \mathrm{v}$.

- Nomenaments anuals de substitut del canonge rector de les escoles de cant de la catedral de València: $E-V A c$, vol.3596, f. 10v-12v (26 d'abril de 1486); ibid., f. 76-78r (28 d'abril de 1487); ibid., vol. 3605, f. 110r-110v, 117r (29 d'abril de 1488); ibid., f. 111r-111v, 116r (27 d'abril de 1489); ibid., f. 112r-112v, 115r (26 d'abril de 1490); ibid., f. 113r-114r (7 d'abril de 1491); ibid.,f. 118r-119v (27 d'abril de 1492); ibid., f. 149r-150r (29 d'abril de 1493); ibid., f. 151r-152r (22 d'abril de 1494); ibid., vol. 3596, f. 133r-133v, 138 (30 d'abril de 1495); ibid., f. 134r-134v, 137r (29 d'abril de
1496); ibid., f. 135r-135v, 136r (28 d'abril de 1497); ibid., f. 132r-132v, 139r (27 d'abril de 1498); ibid., vol. 3605, f. 10r-11r (29 d'abril de 1499).

- Cobraments (catedral de Barcelona): oficis de matines [ $E$ $B c$, catedral, sagristia, sagristia en general, 1445-1447, f. 32r, 83v; ibid., 1447-1449, f. 72r; ibid., f. 94r; ibid., 14511452, f. 34v; ibid., 1453-1455, f. 39v; ibid., f. 92v; ibid., 1455-1457, f. 40v; ibid., f. 95v]; oficis de completes els dissabtes de Quaresma en la capella de Santa Eulàlia $[E$ $B c$, catedral, sagristia, sagristia en general, 1445-1447, f. 32r, 85r; ibid., 1447-1449, f. 73r, 95r; ibid., 1451-1452, f. 36v; ibid., 1452-1453, f. 37v; ibid., 1453-1455, f. 39v, 92v; ibid., 1455-1457, f. 41r, 95v]; misses de la Translació i Martiri de Sant Sever $[E-B c$, arxiu de Sant Sever, comptes dels procuradors, 1444-1446, s/f, s/d ; $E-B c$, arxiu de Sant Sever, comptes dels procuradors, 1447-1448, s/f, s/d; ibid., 1448-1449, s/f, s/d; ibid., 1450-1451, s/f, s/d; ibid., 14511452, s/f, s/d; ibid., 1453-1454, s/f, s/d].

- Cobraments (cort de Joan II) : E-VAar, Mestre Racional, vol. 8815, f. 176v (any 1460); ibid., vol. 8804, f. 97r, 137r (any 1461); ibid., vol. 8817, f. 79r (any 1468); ibid., vol. 8822, f. 44r, 48v (any 1471); ibid., vol. 8823, f. 26v, 39r (any 1471); ibid., vol. 8825, f. 29r (any 1472); ibid., vol. 8831, f. 36r (any 1478).

- Cobraments (catedral de Girona): misses d'aniversaris presbiterals, anomenades d'estaca $[E-G$, Aniversaris presbiterals, llibres de comptes, any 1476 , f. 40v, 42v, 43r, 44v, 45r, 45v, 46r, 46v, 47v; ibid., any 1478, f. 40r, 40v, 41r, 41v, 42r, 42v; ibid., any 1479, f. 40r, 41r].

- Cobraments (pensió reial de 30 lliures valencianes): E-VAcp, not. Joan Cardona, vol. 6516, s/f, 14 d'abril de 1497; ibid., vol. 6517, s/f, 4 de gener de 1499; ibid., vol. 6519 , s/f, 3 d'agost de 1500 .

Bibliografia (només aspectes biogràtics)

FITA (Barcelona, 1871-1873): 25 d'octubre de 1872, 229; (Barcelona, 1871-1873): 15 de desembre de 1872, 274; (1876): 26-27. PEDRELL (1897): 481; REAL ACADEMIA DE LA HISTORIA (1904-1922): vol. 24, 145-146, 155, 166167; (1904-1922): vol. 25, 19-20, 31-32, 200, 263. MAS (Barcelona, 1917): 25 de desembre de 1917, 2. ANGLÉS, 2 (Barcelona, 1947): 158. MADURELL, 6 (Barcelona, 1951): 206. ANGLÉS (1975b): 890. CIVIL CASTELLVÍ, 58 (Girona, 1er trimestre 1972): 79. GREGORI I CIFRÉ, III (Barcelona, 1983): 11; 28 (Girona, 1985-1986): 281-282. NICOLAU BAUZÀ, 17 (València, gener-març de 1986): 14. DALMASES BALAÑÁ (1992): 100. VILLANUEVA SERRANO, 65 (Barcelona, 2010): 3-23; 30 (Saragossa, 2014a): 20-21, 24, 30-32, 34-35, 62-63; (2015): vol. I, 49168. 
Joan Mont $\rightarrow$ Joan Roger àlies Mont

\section{Joan Montesino}

Mestre dels diputats / Catedral de València

El 1467 ja era prevere resident a la seu de València com a simple beneficiat. Va ocupar l'ofici d'altar de domer almenys del 1490 a la seua mort i era sotsobrer l'any administratiu de 1494. Almenys en el període del 1490 al 1498 fou mestre dels diputats, i es feia càrrec del manteniment d'aquests. Va morir a València el 19 o el 20 de setembre de 1505. Entre els seus béns hi havia una flauta, un monacord i quatre passions en notació, probablement de Guillem de Podio.

Documents

- 14 de gener de 1467. És prevere beneficiat a la seu de València [E-VAc, not. Joan Esteve, vol. 3587, s/f].

- 26 de juliol de 1490. És domer i mestre dels diputats de la seu de València [E-VAc, not. Jaume Esteve, vol. 3685, $\mathrm{s} / \mathrm{f}]$.

- 30 d'abril de 1491. És sotsobrer de la seu de València [E-VAc, not. Jaume Esteve, vol. 3686, s/f].

- 11 de juliol de 1494. És domer i mestre dels diputats de la seu quan cobra una ajuda per la malaltia i la sepultura d'un diputat anomenat Miquelot $[E-V A c$, Almoina, Procura major, any 1494 , vol. 5686, f. 42r].

- 6 d'agost de 1496. Demana al sagristà de la seu de València que els diputats no facen certes tasques [E-VAc, not. Jaume Esteve, vol. 3687, s/f].

- 16 de juny de 1497 . És domer de la seu i ven a Bernat Fenollar, domer de la seu, 200 sous d'un violari [E-VAcp, not. Guillem Ramon Tovia, vol. 26404, s/f].

- 22 de novembre de 1498. És prevere i compra roba per als diputats $[E-V A c$, Tresoreria, any 1498, vol. 1291, any $1498, \mathrm{~s} / \mathrm{f}]$.

- 4 de gener de 1502. És domer de la seu i rep els drets de cobrament del preu d'una mula que havia venut el vidrier Julià Fabregat [E-VAcp, not. Guillem Ramon Tovia, vol. 26403, s/f].

- 19 de setembre de 1505. Darrer testament de Joan Montesino, domer de la seu. Fa marmessors Bartomeu Esteve, domer de la seu, i Joan Bexix, sotsdiaca de la seu. Fa hereua Francina Llorenç. Publicació al dia següent [E-VAcp, not. Guillem Ramon Tovia, vol. 26408, s/f].

- 20 de setembre de 1505. Inventari post mortem dels béns de Joan Montesino. [E-VAcp, not. Guillem Ramon Tovia, vol. 26408, s/f];

- 24 de setembre de 1505. Encant dels béns de Joan Montesino [E-VAcp, not. Guillem Ramon Tovia, vol. 26408, s/f];

\section{Lluís Navarro}

Cantor / Catedral de València

Era un frare de l'orde de Sant Domènech. Va ser despedit de la seu valenciana com a cantor poc abans de mitjan 1505 . Es desconeix quant de temps va exercir l'ofici però sembla que havia sigut admès poc abans. Per raons cronològiques és improbable, malgrat que no impossible, que fos el cantor homònim que servia Alfons el Magnànim a Nàpols el 1451. Document

- 16 de maig de 1505. "Frare Lois Navarro, frare de Predicadors", cantor, cobra 2 lliures, 4 sous i 2 diners de prorrata del temps que havia servit, a més de 5 lliures que li dóna el capítol "com li donaren comiat" [E-VAc, Almoina, Procura major, vol. 5688, any 1505, f. 38r].

Bibliografia

ANGLÉS (1975a): 1022. ATLAS (1985): 32, 94.

\section{Agostí Pastor}

Diputat / Catedral de València

Va ser diputat de la seu de València. Possiblement després va continuar algun any més en contacte amb la seu beneficiantse del senyal que els capitulars solien atorgar als antics diputats. De qualsevol manera, el maig de 1496 havia deixat de gaudir-la.

\section{Documents}

- 9 de maig de 1496. El capítol de València ordena que el senyal que tenia com a diputat o antic diputat siga adjudicada al cantor Honorat Strimundi [E-VAc, not. Jaume Esteve, vol. 3687, any 1496, s/f].

- 7 de maig de 1497. El capítol atorga el senyal que tenia a Nicolau Feliu, diputat, per a estudiar gramàtica $[E-V A c$, not. Jaume Esteve, vol. 3687, any 1497, s/f].

\section{Pedro [Pere, Pero] Pérez}

Cantor / Catedral de València

Va arribar a València durant l'any administratiu de 1501, probablement poc abans del 20 de desembre de 1501, puix aquest dia li foren concedits dos senyals com a salari de cantor per part del capítol. A més, va rebre una ajuda econòmica per a establir sa casa a valència. Era frare i possiblement castellà, atès que escrivia els albarans en aquesta llengua. El darrer pagament localitzat, prorrata d'una terça, està datat el 22 de juliol de 1503. Cronològicament, no es pot descartar, la identificació amb Petrus Pérez de Rezola, cantor de la diòcesi de Tortosa, que es va incorporar el 1510 a la capella papal i que continuava servint allà el 1512 , malgrat que no sembla probable per l'origen. 


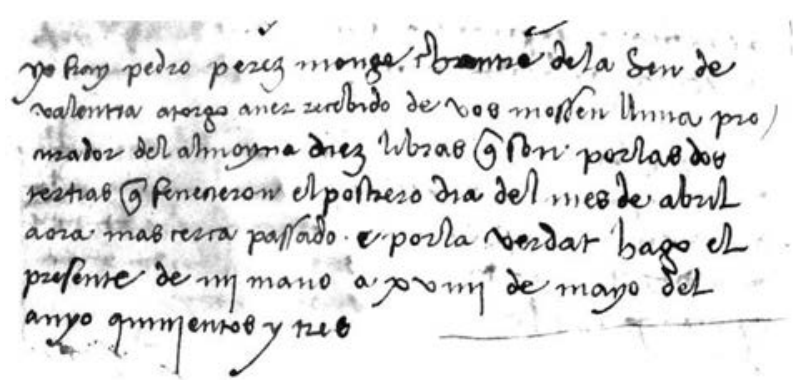

E-VAc, Almoina, Procura Major, vol. 5687, any 1502, f. $87 \mathrm{v}$.

\section{Documents}

- Any administratiu de 1501. El frare Pérez, monjo i xantre de la seu, cobra "per subvenció de parar casa, com ara novament sia arribat en la present ciutat" [E-VAc, Almoina, Procura major, vol. 5687, any 1501, f. 41v].

- Any administratiu de 1501. El frare Pérez cobra pels dos senyals atorgats el 20 de setembre de 1501 pel salari de xantre, carregats al procurador major de l'Almoina mentre no vaquen dos del capítol [E-VAc, Almoina, Procura major, vol. 5687, any 1501, f. $41 \mathrm{v}]$.

- Cobraments: E-VAc, Almoina, Procura Major, vol. 5687, any 1502 , f. $38 \mathrm{v}, 41 \mathrm{v}, 83 \mathrm{r}, 87 \mathrm{v}$; ibid. any 1503 , f. $43 \mathrm{v}$.

Bibliografia

SHERR, 20:4 (Oxford, novembre de 1992): 602.

Guillem de Podio $\rightarrow$ Guillem Molins àlies de Podio

\section{Guillem [Guillem Jeroni de] Rabós}

Cantor - Mestre dels diputats / Catedral de València - Capella de l'infant Enric

D'origen valencià, a l'abril de 1490 ja era prevere cantor de la seu de València. En aquest moment únicament disposava d'un salari de dos senyals, però només dos anys més tard va incrementar els ingressos en ser admès a rebre els percaços de la seu. Després del 1494 i, en tot cas, abans de mitjan 1499 va ingressar com a cantor en la capella de l'infant Enric d'Aragó. De fet, és possible que ja estiguera al seu servei quan el 1498 va rebre una sotscabiscolia a l'església d'Albarrassí que, segurament, va gaudir econòmicament sense exercir directament l'ofici. La proximitat a l'infant, aleshores virrei de València (1496-1505), potser va facilitarli la possessió d'altres rendes eclesiàstiques al regne valencià com ara les d'un benefici a la parròquia de Sant Llorenç a València, un altre a l'església d'Almassora o la vicaria perpètua del lloc de Domenyo. El 1506 tornava a ser cantor de la seu valenciana amb dos senyals de salari que anaven a càrrec del procurador major de l'Almoina, però el 1508 el capítol va decidir que li'ls pagara diàriament el pagador. El retorn a la catedral va estar associada també a l'exercici del magisteri i cura dels fadrins diputats, per la qual cosa va rebre diverses quantitats extraordinàries en concepte de roba a través de la Tresoreria. El seu darrer testament, redactat en estat de malaltia, ens revela, entre altres coses, que pertanyia a la confraria de la Verge Maria de la Seu i que tenia família a la ciutat. No obstant això, la persona més beneficiada va ser una veterana criada, a la qual va deixar gran part dels seus béns mobles. Va tenir en comanda un cèmbal d'un prevere anomenat Miquel Romeu, el qual va ser venut pel propi Rabós. Posseïa una casa al carrer de la Morera d'En Carròs a la parròquia de Sant Esteve, on va morir el 29 de gener de 1517. Entre els llibres que es trobaren a l'inventari post mortem hi havia d'alguns litúrgics -un parell d'oficiers pertanyien a la catedral-, així com quatre llibres de cant -almenys un d'ells era amb seguretat de polifonia-, i tres de teoria musical -dos que apareixen a l'inventari titulats Art de cant i un altre de Boeci-.

\section{Documents}

- 20 d'agost de 1492. El capítol de la seu de València l'admet a percaços [E-VAc, not. Jaume Esteve, vol. 3605, s/f].

- El 15 d'octubre de 1498. És referit com a valencià quan nomena dos procuradors per a prendre possessió d'una sotscabiscolia a l'església del Salvador d'Albarrasí [E-VAc, not. Jaume Esteve, vol. 3687, s/f].

- 23 de juliol de 1499. És cantor de la capella de l'infant Enric d'Aragó i cedeix els drets de cobrament de les quitacions de setembre i octubre següents [E-VAcp, not. Garcia Uguart, vol. 20128].

- 11 de setembre de 1499. És beneficiat de la parròquia de Sant Llorenç de València [ADV, Manuale, vol. 337/001, $\mathrm{s} / \mathrm{f}]$.

- 22 d'abril de 1504. És vicari perpetu del lloc de Domenyo però habitant de València quan fa una cessió econòmica [E-VAar, not. Joan Garcia, vol. 4532, s/f].

- 25 d'abril de 1504. És beneficiat de Sant Miquel Arcàngel a l'església d'Almassora i nomena procurador per a cobrar [E-VAar, not. Pere Botella, vol. 331, s/f].

- Any administratiu de 1508 . Des de l'1 de novembre de 1508 li donaven els senyals del seu salari de la seu de València a l'Almoina en lloc de fer-ho el procurador major [E-VAc, Almoina, Procura major, vol. 3596, any 1508 , f. 38v].

- 20 de gener de 1517. Darrer testament de Guillem Rabós, prevere [ADPV, not. Felip Martí major, vol. e.5.1/4, s/f]. - 31 de gener de 1517. Inventari post mortem de béns Guillem Rabós [ADPV, not. Felip Martí major, vol. e.5.1/4, s/f]. - 6-7 de febrer de 1517. Encant de béns de Guillem Rabós [ADPV, not. Felip Martí major, vol. e.5.1/4, s/f]. 
- Cobraments: E-VAc, Almoina, Procura Major, vol. 5685, any 1489 , f. 36r; ibid., vol. 5686, any 1490 , f. 31 v; ibid., any 1491 , f. $31 \mathrm{v}$; ibid., any 1492 , f. 52v; ibid., any 1493 , f. 44r; ibid., vol. 5688, any 1506, f. 49v; ibid., any 1507, f. 40v; ibid., any 1508, f. 38v; ibid., Pagador dels senyals, vol. 5614, anys 1511-1516, s/f. E-VAc, Tresoreria, vol. 1292 , anys $1510,1512,1515 E$-VAc, not. Jaume Esteve, vol. 3685, any 1490, s/f, 16 d'agost de 1490; ibid., any 1491, s/f, 20 de maig de 1491, 9 de desembre de 1491; ibid., any 1492, s/f, 21 de març de 1492, 6 de juliol de 1492, 10 de novembre de 1492; ibid., any 1493, s/f, 23 de febrer de 1493, 25 de maig de 1493, 28 d'agost de 1493.

\section{Francesc Robiols}

Sotscabiscol / Catedral de València

El 1459 ja era prevere sotscabiscol de la seu de València i rector de Corts a la diòcesi de València. Segurament era natural de València ja que tenia divers familiars a la ciutat, amb professions (mercaders, notaris) que denoten una benestant posició. Va acumular diversos beneficis. A la fi de la seua vida posseïa la rectoria de Dosaigües i beneficis a les esglésies valencianes de Sant Joan de l'Hospital, de Sant Nicolau i de Sant Martí, així com a la seu de València. Abans havia gaudit d'altres a les parròquies de la Santa Creu i de Sant Tomàs, al monestir de Magdalenes, i a la capella de sant Francesc de la seu. Va mantenir el seu ofici de sotscabiscol fins la seua mort, ocorreguda entre el 13 de febrer (data d'atorgament del darrer testament) i el 2 de març de 1484 (data de la lectura). La bona situació económica també es reflecteix en el fet que comptava amb tres servidors a sa casa. Els seus llibres citats en el testament eren litúrgics, religiosos i de poesia.

Documents

- 12 de novembre de 1459. És prevere sotscabiscol de la seu de València i rector de la parròquia de Corts $[E-V A c$, not. Joan Esteve, vol. 3679, s/f].

- 13 de febrer de 1484. Darrer testament de Francesc Robiols, prevere sotscabiscol de la seu de València [E-VAcp, not. Garcia Uguart, vol. 8402, s/f].

\section{Francesc Roig}

Sotscabiscol / Catedral de València

El 1484 li fou concedida la sotscabiscolia que havia posseït Francesc Robiols, només unes setmanes després de la mort d'aquest. No obstant això, degué exercir-la únicament fins mitjan 1486, ja que aleshores va rebre autorització del capítol per a permutar-la amb Joan Roger.

\section{Documents}

- 22 de març de 1484. És nomenat sotscabiscol per mort de Francesc Robiols [E-VAc, not. Joan Esteve, vol. 3683, s/f].
- 28 de juliol de 1486. És autoritzat pel capítol de la seu de València per a permutar la sotscabiscolia amb Joan Roger [E-VAc, not. Joan Esteve, vol. 3596, f. 47v-48r].

\section{Joan Roger àlies Mont}

Sotscabiscol / Catedral de València

El seu testament i el seu codicil testimonien que la seua família estava arrelada a València, d'on possiblement fou natural. A mitjan 1486, ja ordenat prevere, degué prendre possessió d'una de les sotscabiscolies de la seu de València per permuta amb l'anterior titular Francesc Roig. Va ser una de les tres persones que el capítol va elegir el 1503 per a corregir un breviari segons els costums de l'església valenciana que havia autoritzat imprimir. Va mantenir l'ofici de sotscabiscol fins la seua mort, que tingué lloc el 10 de gener de 1516.

\section{Documents}

- 28 de juliol de 1486. És autoritzat pel capítol de la seu de València per a obtenir una sotscabiscolia per permuta amb Francesc Roig [E-VAc, not. Joan Esteve, vol. 3596, f. $47 \mathrm{v}-48 \mathrm{r}]$.

- 7 de gener de 1500. Joan Roger àlies Mont és sotscabiscol de la seu de València i executor en la possessió d'un benefici [ $E$-VAc, not. Jaume Esteve, vol. 3688, s/f].

- 10 de febrer de 1503. El capítol de la seu de València el tria, juntament amb altres dues persones, per a corregir el breviari segons els costums de l'església valenciana, la impressió del qual havia sigut autoritzada pel capítol al llibrer Gaspar Trincher i a l'impressor alemany Cristòfol Koffman per un període de dos anys [E-VAc, not. Jaume Esteve, vol. 3688, s/f] .

- 4 de juliol de 1509. És sotscabiscol de la seu de València [E-VAc, Fàbrica, vol. 1485, any 1491, f. 18r].

- 13 de desembre de 1514. Darrer testament de Joan Roger, prevere sotscabiscol de la seu de València $[E-V A c p$, not. Jaume Albert, vol. 11280, f. 67r-70r].

- 19 de desembre de 1514. Darrer codicil de Joan Roger, prevere sotscabiscol de la seu de València $[E-V A c p$, not. Jaume Albert, vol. 11280, f. 70v].

\section{Pedro de Rogés}

Cantor / Catedral de València

L'únic document localitzat d'aquest músic mostra que va ser cantor de la seu valenciana des del 8 d'abril de 1505 fins el 31 de juliol de 1505 però no es pot descartar que el seu període com a cantor fóra més llarg. No era sacerdot, atenent al tractament d'"en" que rep.

\section{Documents}

- 16 de maig de 1505. Pedro de Rogés, cantor, cobra la prorrata des del 8 d'abril al 31 de juliol de $1505[E-V A c$, Almoina, Procura major, vol. 5688, any 1505, f. 38r]. 


\section{Pere Pau Rossell}

Canonge rector de les escoles del cant / Catedral de València Va nàixer en una família de ciutadans acomodats de València. Son pare, Pau Rossell, era notari d'aquesta ciutat quan el rei Joan II va nomenar-lo escrivà de ració de la casa reial, pocs dies després de pujar al tron a mitjan 1458. És molt possible que, en aquests moments o durant la primera visita reial a València, Pere Pau Rossell fóra inscrit com a escolà a la capella reial, puix "Pau Rossell" figura el 22 de febrer de 1459 en aquest ofici. El 1461 ja gaudia de tres beneficis a València, un d'ells a la mateixa catedral. La influència en la cort de son pare li degué facilitar que el 1468 fóra presentat pel mateix monarca per a obtenir la rectoria del palau del Real de València, encara que finalment Joan II va canviar d'opinió. Potser com a compensació, l'any següent va ser nomenat capellà reial, moment en què ja era batxiller en dret i posseïa un canonicat a la col·legiata de Xàtiva, així com la rectoria de Murla. El 1477, després de doctorar-se en dret, va ser nomenat en el càrrec d'escrivà de ració del rei, conjuntament amb son pare. El 1486 va rebre un canonicat a la seu de València. A partir d'aleshores pot constatar-se la residència permanent en aquesta ciutat, encara que és possible que abans ja hi visquera. El 1489 era hereu universal de son pare. Fou nomenat canonge rector de les escoles de cant de la seu valenciana durant nombrosos anys administratius (1487-1494, 1497-1499, 1501), essent en aquest temps, per tant, el superior jeràrquic del mestre Guillem de Podio. Del 6 d'agost al 12 d'octubre de 1503 va estar a Saragossa per a resoldre assumptes del capítol. Encara vivia a mitjan 1504.

\section{Documents}

- Era fill de Pau Rossell, natural de València i escrivà de ració del rei [E-VAar, Reial Cancelleria, reg. 422, f. 160r-161r].

- 25 de juliol de 1458. Joan II nomena Pau Rossell, notari de València, com a escrivà de ració $[E-B a c$, Cancelleria Reial, reg. 3357, f. 58r-59r].

- 22 de febrer de 1459. És escolà i està amb la capella reial a València [E-VAcp, not. Mateu Cirera, vol. 21868, s/f].

- 1461. Té un benefici a la seu de València sota l'advocació de Santa Maria Magdalena, un altre en la parròquia de Sant Martí a l'altar major i un darrer en la parròquia de Santa Caterina, sota l'advocació de Sant Andreu [E-VAc, Càmbra apostòlica, vol. 4478, f. 17v, 49r, 53v].

- 5 d'octubre de 1468. Joan II reconeix que l'havia presentat a la rectoria del Real i al benefici annex a la seu, però aquest dia retira la presentació per atorgar-la al seu cantor Antoni Eximénez [E-VAar, Reial Cancelleria, reg. 292, f. 42r].

- 19 de juliol de 1469. Pere Pau Rossell, batxiller en decrets, canonge de Xàtiva i rector de Murla, és inscrit com a capellà del rei $[E-B a c$, Reial Patrimoni, Mestre Racional, Sèries generals, 939, f. 68r].
- 14 de desembre de 1477. Joan II nomena Pere Pau Rossell, doctor en decrets, canonge de Xàtiva i capellà reial, en l'ofici d'escrivà de ració juntament amb son pare i de voluntat d'aquest [E-VAar, Reial Cancelleria, reg. 422, f. 160r-161r].

- 11 de maig de 1486. Pren possessió d'una canongia a la seu de València [E-VAc, not. Joan Esteve, vol. 3596. f. 2r]. - 28 d'abril de 1487. El capítol de la seu de València el nomena rector de les escoles del cant de la seu per a l'any administratiu de 1487 [ $E$-VAc, not. Joan Esteve, vol. 3596, f. $75 \mathrm{v}-78 \mathrm{r}]$.

- 29 d'abril de 1488. El capítol de la seu de València el nomena rector de les escoles del cant de la seu per a l'any administratiu de 1488 [E-VAc, not. Jaume Esteve, vol. 3605 , f. 110r-110v, 117r].

- 26 de novembre de 1489. És hereu universal de son pare Pau Rossell [E-VAcp, not. Andreu Cirera, vol. 20627].

- 26 d'abril de 1490. El capítol de la seu de València el nomena rector de les escoles del cant de la seu per a l'any administratiu de $1490[E-V A c$, not. Jaume Esteve, vol. 3605 , f. $112 \mathrm{r}-112 \mathrm{v}, 115 \mathrm{r}]$.

- 7 d'abril de 1491. El capítol de la seu de València el nomena rector de les escoles del cant de la seu per a l'any administratiu de 1491 [E-VAc, not. Jaume Esteve, vol. 3605 , f. 113r-114r].

- 27 d'abril de 1492. El capítol de la seu de València el nomena rector de les escoles del cant de la seu per a l'any administratiu de 1492 [E-VAc, not. Jaume Esteve, vol. 3605 , f. $118 \mathrm{r}-119 \mathrm{v}]$.

- 29 d'abril de 1493. El capítol de la seu de València el nomena rector de les escoles del cant de la seu per a l'any administratiu de 1493 [E-VAc, not. Jaume Esteve, vol. 3605 , f. 149r-150r].

- 22 d'abril de 1494. El capítol de la seu de València el nomena rector de les escoles del cant de la seu per a l'any administratiu de 1494 [E-VAc, not. Jaume Esteve, vol. 3605 , f. 151r-152r].

- 28 d'abril de 1497. El capítol de la seu de València el nomena rector de les escoles del cant de la seu per a l'any administratiu de 1497 [ $E$-VAc, not. Joan Esteve, vol. 3596, f. $135 \mathrm{r}-135 \mathrm{v}, 136 \mathrm{r}]$.

- 27 d'abril de 1498. El capítol de la seu de València el nomena rector de les escoles del cant de la seu per a l'any administratiu de 1498 [E-VAc, not. Joan Esteve, vol. 3596, f. $132 \mathrm{r}-132 \mathrm{v}, 139 \mathrm{r}]$.

- 29 d'abril de 1499. El capítol de la seu de València el nomena rector de les escoles del cant de la seu per a l'any administratiu de 1499 [E-VAc, not. Jaume Esteve, vol. 3605$, f. $10 \mathrm{r}-11 \mathrm{r}]$. 
- 26 d'abril de 1501. El capítol de la seu de València el nomena rector de les escoles del cant de la seu per a l'any administratiu de 1501 [ $E$-VAc, not. Joan Esteve, vol. 3596, f. $102 \mathrm{r}-103 \mathrm{v}]$.

- 18 de gener de 1504. Rep un cobrament de la seu de València corresponent al període del 6 d'agost al 12 d'octubre de 1503 , quan va estar a Saragossa per assumptes del capítol [E-VAc, not. Jaume Esteve, vol. 3689, 18 de gener de 1504]. Bibliografia

PONS ALÓS i CÁRCEL ORTÍ, 35:2 (Barcelona, 2005): 946.

\section{Lope de Sagredo [Segredo]}

Cantor / Catedral de València - Capella de l'arquebisbe de Saragossa - La Seo de Saragossa

Va ser admès oficialment com a clergue cantor de la seu de València el 26 de maig de 1488 amb un salari de dos senyals. No obstant això, sembla que un temps abans ja exercia aquest ofici, puix la setmana anterior li pagaven el cost del drap per a un sobrepellís. Només dos mesos després, va obtenir un permís retribuït del capítol per a viatjar a la seua desconeguda diòcesi amb motiu de rebre la documentació que li permetera ordenar-se in sacris. És possible que no tornara, atès que no es disposa de més documentació fins vuit anys més tard, moment en què consta un nou acte d'admissió com a cantor de la seu valenciana, encara clergue, amb el mateix salari que tenia però amb dret a rebre els percaços. A més, només unes setmanes després rebia una subvenció extraordinària que podria estar relacionada amb algun viatge. Una vegada més, sembla que va absentar-se poc de temps després, puix els seus senyals varen ser reassignats a un nou cantor l'1 de març de 1497. Es desconeix quan, però va tornar de bell nou. El 9 d'abril de 1502 assegurava la seua permanència mínima d'un any a la catedral, a canvi de rebre a la bestreta l'import anual d'un senyal. Des d'aleshores fins al Nadal de 1503 pot constatar-se documentalment la seua presència a la seu valenciana. També pot assegurar-se que el 1511 no hi era. És possible que des de València viatjara a la capital d'Aragó i s'establira allà. El fet és que el 1515 , ja ordenat de prevere, era cantor de don Juan de Aragón, arquebisbe de Saragossa. En dissoldre's la capella del pontífex el 1530 va passar a $L a$ Seo de Saragossa, on encara servia el 1532.

\section{Documents}

- 26 de maig de 1488. És referit com a xantre quan rep de la seu valenciana 10 reals i diners per drap per a un sobrepellís [E-VAc, Almoina, Procura major, vol. 5685, any 1488 , f. 33r-34v].

- 2 de juny de 1488. És admès com a clergue xantre de la seu de València i li adjudiquen dos senyals de salari $[E-V A c$, not. Jaume Esteve, vol. 3685, s/f].
- 13 d'agost de 1488. El capítol li concedeix llicència per a anar a la seua diòcesi a rebre la documentació necessària per promoure's a ordes sagrades sense perdre els ingressos dels dos senyals que té sempre que no prolongue més de dos mesos l'absència [E-VAc, not. Jaume Esteve, vol. 3685, s/f]. - 14 de setembre de 1496. És encara clergue i torna a ser admès com a cantor amb percaços i salari de dos senyals consignats al procurador major de l'Almoina [E-VAc, not. Jaume Esteve, vol. 3687, any 1496, s/f].

- 17 d'octubre de 1496. El capítol li concedeix 100 sous de subvenció $[E-V A c$, Almoina, Procura Major, vol. 5686, any 1496, f. 38v]

- 1 de març de 1497. A causa de la seua absència, assignen els seus dos senyals al nou cantor fra Ramón Damià $[E-V A c$, not. Jaume Esteve, vol. 3687, any 1497, s/f].

- 9 d'abril de 1502 . És cantor i s'obliga a servir l'any vinent complet, a canvi que l'avancen l'import d'un dels dos senyals que té $[E-V A c$, not. Jaume Esteve, vol. 3688, s/f].

- Cobraments (catedral de València): $E$-VAc, Almoina, Procura Major, vol. 5658, any 1488, f. 33r; ibid., vol. 5687, any 1502, f. 39r, 41r; ibid., any 1503 , s/f. $E$-VAc, not. Jaume Esteve, vol. 3688, any 1503, s/f, 10 de març de 1503; E-VAc, not. Jaume Esteve, vol. 3605, f. 216 r.

Bibliografia

CALAHORRA MARTÍNEZ (1978): vol. 2, p. 15-16, 166.

\section{Garcia Salelles}

Cantor / Catedral de València

Va ser cantor de la seu de València, però es desconeix el període exacte en què va exercir aquest ofici. Només se sap que ho era el 28 de març de 1496, quan el capítol va atorgarli el prorrateig d'un senyal d'un altre cantor absent.

Document

- 28 de març de 1496. El capítol de la seu de València ordena que reba el prorrateig d'un dels senyals d'Honorat Strimundi, a causa de l'absència d'aquest darrer [E-VAc, not. Jaume Esteve, vol. 3687, any 1496, s/f].

\section{Juan (Rodríguez) (de) Sanabria}

Cantor / Catedral de Burgos - Catedral d'Àvila - Catedral de Lleó - Catedral de Múrcia (?) - Catedral de València

La trajectòria professional fins ara coneguda de Juan de Sanabria el vinculava únicament a tres centres catedralicis castellans. El 12 d'abril de 1484 va ser admès com a cantor a la catedral de Burgos amb obligacions docents però no va passar allí massa temps, puix l'1 de febrer del 1487 era nomenat mestre de cant de la catedral d'Àvila. La darrera notícia que de Sanabria estava incorporada a la seua biografia l'ubicava a la catedral de Lleó, on havia ingressat com a cantor el gener de 1494. És possible que, 
posteriorment, estiguera a la catedral de Múrcia, si és que es pot identificar amb un Sanabria que havia sigut cantor, amb funcions docents, en aquest temple poc abans del 30 de setembre del 1502. Aquest dia, el capítol murcià admetia un altre cantor amb les mateixes obligacions que tenia Sanabria "es a saver que mostrase canto de organo a los benefficiados e capellanes e moços que fuesen abiles para deprender canto y que cantase con los dichos benefficiados y capellanes y moços los dias solemnes". Casualitat o no, immediatament pot trobar-se Juan de Sanabria a la seu de València, on fou admès el 5 d'octubre de 1502 com a cantor pel capítol, el qual li va assignar dos senyals de l'Almoina com a salari. També va tenir una breu trajectòria a la catedral valenciana, atès que fou despedit pel capítol a la fi del mes de març de 1503 i va rebre el darrer pagament l'1 d'abril. Se sap que tenia cert prestigi al camp de la teoria musical ja que el seu nom figura en una anotació marginal en relació a una qüestió polèmica sobre la divisió del to a l'única còpia conservada del tractat l'Enchiridion de principiis musice discipline de Guillem de Podio "[I-Bc, A.71, p. 148]", anotació que segurament correspon a l'etapa valenciana. No es coneixen obres teòriques atribuibles amb certesa a aquest músic. No obstant això, a hores d'ara no es pot descartar que Juan Rodríguez de Sanabria fóra el mateix Juan Rodríguez que, segons François Joseph Fétis, fou natural de Salamanca, "chantre" (en francès) a la catedral d'aquesta ciutat i autor d'un tractat de cant pla, hui perdut, publicat també a Salamanca el 1503. Sanabria es autor de dues peces en castellà al Cançoner de Palau: Mayoral $[E$ Mp, II-335, f. 70v-71r] i Descuidad d'ese cuidado [ibid., f. 251v; núm. 377]. Dues peces en llatí es conserven en el ms. 2-3 de la catedral de Tarassona: l'himne Cuius corpus Sanctissimum [E-TZ, f. 7v-8r] i el motet Lillium sacrum [ibid., f. 110v-111r]. Actualment pot descartar-se la possibilitat que aquest músic poguera identificar-se amb Juan Rodríguez de la Torre, cantor d'Isabel la Catòlica del 1495 al 1505.

\section{Documents}

- 18 de gener de 1503. El capítol de la seu de València proveeix que el procurador major de l'Almoina pague dos senyals anuals "Johanni Rodrigues de Sanabria", prevere cantor de la seu, començant el 5 d'octubre de 1502, quan fou admès al servei de la mateixa institució $[E-V A c$, not. Jaume Esteve, vol. 3605, actes del capítol, s/f].

- 24 de març de 1503. "Johannes de Sanabria", cantor, reconeix haver cobrat 6 lliures, 18 sous i 4 diners del procurador major de l'Almoina del període de 6 d'octubre de 1502 a 20 de març de 1503 per raó dels 2 senyals que li dóna el capítol de salari [E-VAc, not. Jaume Esteve, vol. 3688 , any $1503, \mathrm{~s} / \mathrm{f}]$.
- 24 de març de 1502. "Mossèn Johan Sanabria", cantor, cobra 6 lliures, 18 sous i 4 diners del procurador major de l'Almoina del període de 6 d'octubre de 1502 a 20 de març de 1503 per raó dels 2 senyals [E-VAc, Almoina, Procura Major, vol. 5687, any 1502, f. 41r].

- 1 d'abril de 1502. "Mossèn Sanabria", cantor, cobra 9 sous i 2 diners del procurador major de l'Almoina per la resta del mes de març "com fos despedit" [E-VAc, Almoina, Procura Major, vol. 5687, any 1502, f. 41r].

Bibliografia (només aspectes biogràfics)

FÉTIS (1888): vol. VII, 288. ANGLÉS (1951): vol 1, 143; (1951), vol. 2, 136. ÁLVAREZ PÉREZ, 14 (Barcelona, 1959): 42. LÓPEZ MARTÍNEZ, 2 (Burgos, 1961): 288, nota 414. MOLL ROQUETA, 22 (Barcelona, 1967): 90-92. LÓPEZ-CALO (1996): 29-30. KNIGHTON (2001a): 342; (2001b): 893. PRATS REDONDO (2009): 143.

\section{Joan Sanç [Sànchiç, Sànxiç] àlies Joanicot [Johanicot, Janicot, Joniquot, Jonichot]}

Cantor / Catedral de València

El 1471 ja era prevere i cantor a la seu de València. L'any següent va aconseguir augmentar a dos l'únic senyal que li pagava de salari el procurador major de l'Almoina, i el 1483 a tres. No obstant això, el 1486 el capítol li va llevar un d'aquests senyals. Era membre de la confraria de la Verge Maria de la Seu. Va tenir una llarga trajectòria com a cantor a la seu, que va mantenir fins la mort. El 1514 va actuar com a testimoni en la redacció del darrer codicil del sotscabiscol de la seu Joan Roger. El seu testament revela que tenia una germana, de nom Miquela, encara que va nomenar hereu Conrat d'Alpont, ciutadà de València. Va morir a l'Hospital General de València el 26 d'agost de 1518.

\section{Documents}

- 26 d'agost de 1472. El capítol de València li concedeix un senyal addicional $[E-V A c$, Almoina, Procura major, vol. 5658 , any 1472 , f. 24 r]

- 19 de desembre de 1486. El capítol de València li lleva un senyal $[E-V A c$, Almoina, Procura major, vol. 5685, any 1486, f. 36v].

- 19 de desembre de 1514. Actua com a testimoni en l'atorgament del darrer codicil del sotscabicol de la seu Joan Roger [E-VAcp, not. Jaume Albert, vol. 11280, f. 67r-70r].

- 28 de novembre de 1517. Darrer testament de Joan Sanç [E-VAcp, not. Felip de Abella, vol. 677, f. 529r-529v].

- Cobraments (seu de València): E-VAc, Almoina, Procura Major, vol. 5685, any 1471, s/f; ibid., vol. 5658, any 1472 , f. $24 \mathrm{r}$; ibid., any 1474 , f. 24r; ibid., vol. 5685, any 1476 , s/f; ibid., any 1477, s/f; ibid., any 1478, s/f; ibid., any 1479 , f. 30v; ibid., any 1480, f. 37r; ibid., vol. 5658, any 1481, 
s/f; ibid., any 1482, f. 32r; ibid., vol. 5685, any 1483, f. $34 \mathrm{v}$; ibid., vol. 5658, any 1484, f. 33v; ibid., any 1485 , f. $33 \mathrm{v}$; ibid., any 1486, f. 33v; ibid., any 1487, f. 31v; ibid., vol. 5658, any 1488, f. 32v; ibid., vol. 5685, any 1489, f. $31 \mathrm{v}$; ibid., vol. 5686, any 1490, f. 31v; ibid., any 1491, f. 31v; ibid., any 1492, f. 52v; ibid., any 1493, f. 43v, 44r; ibid., Pagador dels senyals, vol. 5614, anys 1511-1518, s/f. E-VAc, not. Joan Esteve, vol. 3682, any 1478, s/f, 28 de març de 1478, 7 d'agost de 1478; ibid., any 1479, s/f, 18 de febrer de 1479, 7 de juliol de 1479, 1 de desembre de 1479; ibid., vol. 3683, any 1480, s/f, 22 de febrer de 1480; ibid., any 1481, s/f, 5 de setembre de 1481; ibid., any 1482, s/f, 15 de febrer de 1482, 27 de juliol de 1482, 18 de desembre de 1482; ibid., any 1483, s/f, 16 d'abril de 1483, 28 d'agost de 1483, 28 de novembre de 1483; ibid., any 1484, s/f, 26 de març de 1484, 21 d'agost de 1484, 14 de desembre de 1484,; ibid., any 1485, s/f, 2 d'abril de 1485, 30 de juliol de 1485,20 de desembre de 1485. E-VAc, not. Jaume Esteve, vol. 3685, any 1487, s/f, 30 de maig de 1487, 15 de desembre de 1487, 19 de desembre de 1489; ibid., any 1488, s/f, 11 d'abril de 1488, 16 d'agost de 1488; ibid., any 1489, s/f, 4 d'abril de 1489; ibid., vol. 3686, any 1491, s/f, 13 de maig de 1491, 8 de juliol de 1491, 18 d'octubre de 1491; ibid., any 1492, s/f, 22 de juny de 1492, 8 d'octubre de 1492; ibid., any 1493, s/f, 31 de desembre de 1492, 22 de maig de 1493, 21 d'agost de 1493.

Joan Sànchiç $\rightarrow$ Joan Sanç àlies Joanicot

Joan Sànxiç $\rightarrow$ Joan Sanç àlies Joanicot

Lope de Segredo $\rightarrow$ Lope de Sagredo [Segredo]

Jaume de Sent Just $\rightarrow$ Jaume Just

\section{Andrés de Soria}

Cantor - Mestre de cant / Catedral de València

Era probablement oriünd de Calataiud al regne d'Aragó, localitat on el 1484 vivia sa mare Maria amb alguns nebots, i on posseïa una casa i heretat. Va començar l'activitat com a prevere cantor de la seu de València el 1471 amb el salari d'un senyal, que va ampliar a dos l'any següent. En algun moment entre l'abril i el maig de 1479 va deixar aquest ofici, però el 22 de novembre de 1480 tornava a ser acceptat com a cantor a la catedral amb el mateix salari que tenia. A partir del maig de 1483 va cessar de rebre retribucions per aquest ofici musical en ser-li atorgat un ofici auxiliar d'altar de la seu, diaca o sotsdiaca -encara que en el nomenament figura com a sotsdiaca, en la major part de la documentació posterior és citat com a diaca-. Seguramente viatjà a Roma el 1484, ja que va redactar un testament amb aquest motiu, però el 1486 ja havia tornat a la seu de València. A partir d'aleshores va rebre diversos nomenaments anuals de tipus burocràtic per a exercir com a procurador de les administracions catedralícies de Fàbrica, Dobles i Aniversaris i del Diner Menut. Del maig de 1494 a l'abril de l'any següent va exercir excepcionalment com a mestre de cant en substitució de Guillem de Podio. Sembla que va seguir d'alguna manera en contacte amb la música puix se sap que el 1497 va participar amb un grup de vuit cantors que actuaren en les exèquies de Joan de Borja, duc de Gandia, en nom dels quals va cobrar. Durant la darrera part de sa vida, va gaudir d'una posició econòmica acomodada, assistit per un esclau de raça negra i una criada, a més de la companyia d'almenys un nebot anomenat Andrés de Medina, peraire de professió, el qual finalment seria el seu marmessor i hereu. Vivia en una casa amb hort al carrer de l'Alcaid de Paterna, a la parròquia valenciana de Sant Joan. Posseïa tres cases a la mateixa ciutat i diversos censals que li reportaven 24 lliures anuals. Va morir en el seu domicili entre el $10 \mathrm{i}$ el 19 de febrer de 1518. Entre les seues pertinences hi havia uns pocs llibres litúrgics i uns quaderns de llibres de cant sense enquadernar.

\section{Documents}

- 14 de març de 1472. Primer rebut de cobrament d'un senyal corresponent al salari d'un any com a xantre de la seu de València [E-VAc, Almoina, Procura major, vol. 5685, any 1471, s/f]. Li és concedit un segon senyal de salari de cantor $[E-V A c$, Almoina, Procura major, vol. 5658, any 1472 , f. 24r].

- 26 de maig de 1479. El capítol de la seu de València adjudica al nou cantor Ramon Granyén els dos senyals que rebia Soria [E-VAc, not. Joan Esteve, vol. 3682, any 1479, $\mathrm{s} / \mathrm{f}]$.

- 22 de novembre de 1480. El capítol de la seu de València l'accepta com a xantre amb el salari i prerrogatives que tenia abans [E-VAc, not. Joan Esteve, vol. 3683, any 1480, $\mathrm{s} / \mathrm{f}]$.

- 19 de maig de 1482. Doriano de Bello, escuder de Calataiud, el nomena procurador seu [E-VAcp, not. Bartomeu Bodí, vol. 14401, s/f].

- 25 de maig de 1483. El capítol de la seu de València li atorga l'ofici de sotsdiaca [E-VAc, not. Joan Esteve, vol. 3683 , any $1483, \mathrm{~s} / \mathrm{f}]$.

- 10 de juny de 1483 . Signa rebut de la prorrata del salari de cantor fins al 18 de maig passat [E-VAc, not. Joan Esteve, vol. 3683, any 1483, s/f].

- 10 de juny de 1483 . Cobra la prorrata del salari fins al 18 de maig de 1483 perquè fou nomenat diaca de la seu i li fou llevat l'ofici de xantre [E-VAc, Almoina, Procura major, vol. 5685, any 1483, f. 43v]. 
- 14 de maig de 1484. Testament d'Andrés de Soria, prevere diaca de la seu de València, atorgat perquè vol viatjar a Roma per mar. [E-VAcp, not. Garcia Uguart, vol. 8402, s/f].

- 5 de setembre de 1486. El capítol el nomena procurador de l'administració de Dobles i Aniversaris [E-VAc, not. Jaume Esteve, vol. 3684, s/f].

- 26 de juliol de 1487. És procurador de Dobles i Aniversaris de la seu de València [E-VAc, not. Jaume Esteve, vol. 3685, 26 de juliol de 1487].

- 1 d'abril de 1488. És procurador de Dobles i Aniversaris de la seu de València [E-VAc, not. Jaume Esteve, vol. 3685, 1 d'abril de 1488].

- 22 d'abril de 1494. El capítol de la seu de València el nomena substitut del canonge rector de les escoles del cant o mestre de cant per al següent any administratiu $[E-V A c$, not. Jaume Esteve, vol. 3605, f. 151r-152r].

- 17 de juny de 1497. Cobra 14 lliures i 7 sous per un grup de vuit cantors que actuaren en les exèquies de Joan de Borja, duc de Gandia [E-VAar, Governació, vol. 2427, f. 151v, $153 \mathrm{r}, 155 \mathrm{r}, 156 \mathrm{v}]$.

- 30 d'octubre de 1501. És procurador de l'administració del Diner Menut de la seu de València [E-VAc, not. Jaume Esteve, vol. 3600, f. 90r].

- 4 de juliol de 1503. És citat com a diaca i procurador de l'administració del Diner Menut de la seu de València [E-VAc, not. Jaume Esteve, vol. 3688, s/f].

- 17 de juliol de 1504. És citat com a diaca de la seu de València [E-VAc, not. Jaume Esteve, vol. 3600, f. 427v].

- 20 d'agost de 1513. És citat com a sotsdiaca de la seu de València $[E-V A c$, not. Felip Abella, vol. 3699, s/f] .

- 10 de febrer de 1518. Codicil d'Andrés de Soria, diaca i domer de la seu de València [E-VAcp, not. Alfons d'Ayerve, vol. $20510, \mathrm{~s} / \mathrm{f}]$.

- 20 de febrer de 1518. Inventari de béns post mortem d'Andrés de Soria [E-VAcp, not. Alfons d'Ayerve, vol. 20510, s/f].

- Cobraments: E-VAc, Almoina, Procura Major, vol. 5685, any 1471, s/f; ibid., vol. 5658, any 1472, f. 24r; ibid., any 1474, f. 24r; ibid., vol. 5685, any 1476, s/f; ibid., any 1480 , f. 37r; ibid., vol. 5658, any 1481, s/f; ibid., any 1482, f. 32r. E-VAc, not. Joan Esteve, vol. 3682, any 1478, s/f, 14 de maig de 1478; ibid., any 1479, s/f, 5 de febrer de 1479 , 2 d'abril de 1479; ibid., vol. 3683, any 1482, s/f, 25 de setembre de 1482; ibid., any 1483, s/f, 6 de febrer de 1483, 10 de juny de 1483 .

\section{Gabriel Soria}

Cantor tenorista / Catedral de València

El 1447 ja era cantor tenorista de la seu de València amb salari d'un únic senyal, el qual sembla que mai no va aconseguir incrementar. Era frare de l'orde dominicà o de Predicadors i residia al convent de Sant Domènec de València. El 26 de març de 1458 va ser requerit urgentment pel rei Alfons el Magnànim per a incorporar-se al seu servei a Nàpols. Molt probablement va acudir a aquesta ciutat, puix el 24 de maig rebia, del batlle general de València, 550 sous per al viatge. Però el rei moria només un mes després i, per tant, és possible que ni tan sols arribara a servir-lo. El 23 d'agost ja hi era de nou a la seu valenciana on es reincorporà com a tenorista. Va tenir una llarguíssima trajectòria professional a la catedral, al llarg de la qual també va rebre l'encàrrec d'altres treballs, com ara fer sermons o escriure llibres litúrgics. Durant els darrers anys de vida va rebre l'ajuda econòmica freqüent del capítol per a atendre les seues malalties. El 10 de setembre de 1492 encara vivia, però no s'han trobat documents posteriors.

\section{Documents}

- 24 de maig 1458. Cobra 550 sous del batlle general de València per la despesa del viatge a Nàpols per a incorporar-se al servei del rei Alfons [E-VAar, Batllia General, Àpoques, vol. 50, f. 74r].

- 21 d'abril de 1474. Rep 2 timbres pel sermó de Divendres Sant que féu a la seu de València $[E-V A c$, Fàbrica, vol. 1483 , any 1473 , f. $18 \mathrm{v}]$.

- Any administratiu de 1477 . Rep 20 sous per fer escriure i posar un ofici de Santa Caterina de Sena en l'oficier santoral de la seu de València [E-VAc, Fàbrica, vol. 1483, any 1477 , f. 14 r]

- Cobraments (exhaustiu només en el període d'estudi): E-VAc, Almoina, Procura Major, vol. 5657, any 1447, s/f; ibid., vol. 5657, any 1464, s/f; ibid., any 1465, s/f; ibid., any 1466 , s/f; ibid., vol. 5658, any 1468, f. 25 r; ibid., vol. 5685, any 1470 , s/f; ibid., any 1471 , s/f; ibid., vol. 5658, any 1472 ,f. 24 r; ibid., any 1474 , f. 24 r; ibid., any 1476, s/f; ibid., any 1477 , s/f; ibid., any 1478 , s/f; ibid., any 1479 , f. 30v; ibid., any 1480, f. 37r; ibid., vol. 5658, any 1481, s/f; ibid., any 1482 , f. 32 r; ibid., vol. 5685 , any 1483 , f. $34 \mathrm{v}$, 37v; ibid., vol. 5658, any 1484, f. 33v; ibid., any 1485 , f. $33 \mathrm{v}$; ibid., any 1486 , f. $33 \mathrm{v}$; ibid., any 1487 , f. $31 \mathrm{v}, 34 \mathrm{v}$; ibid., vol. 5658, any 1488 , f. $32 \mathrm{v}$; ibid., vol. 5685, any 1489, f. 31v; ibid., vol. 5686, any 1490, f. 31v; ibid., any 1491 , f. $31 \mathrm{v}$; ibid., any 1492 , f. $18 \mathrm{r}, 52 \mathrm{v}$. E-VAc, not. Joan Esteve, vol. 3679, any 1458, s/f, 23 d'agost de 1458; ibid., any 1459 , s/f, 13 de novembre de $1459 ;$ ibid., any 1460, s/f, 4 de març de 1460, 7 de juny de 1460, 4 de novembre de 1460; ibid., vol. 3682, any 1473, s/f, 12 de gener de 1473 , 24 d'abril de 1473, 17 d'agost de 1473; ibid., any 1478, 7 d'agost de 1478; ibid., any 1479, s/f, 4 de març de 1479; ibid., vol. 3683, any 1481, s/f, 16 de març de 1481, 10 de maig de 1481; ibid., any 1482, s/f, 19 de gener de 1482, 8 
de maig de 1482, 30 d'agost de 1482; ibid., any 1483, s/f, 29 de gener de 1483, 23 de maig de 1483, 29 de setembre de 1483; ibid., any 1484, 14 de febrer de 1484, 21 de maig de 1484, 22 de setembre de 1484, 31 de gener de 1485, 28 de maig de 1485, 20 d'octubre de 1485. E-VAc, not. Jaume Esteve, vol. 3685, any 1487, s/f, 10 de febrer de 1487, 6 de juny de 1487, 10 d'octubre de 1487, 22 de desembre de 1489; ibid., any 1488, s/f, 15 de gener de 1488, 2 de juny de 1488, 19 de setembre de 1488; ibid., any 1490, s/f, abril de 1490, 16 d'agost de 1490, 4 de desembre de 1490; ibid., vol. 3686, any 1491, s/f, 20 d'abril de 1491, 16 de setembre de 1491, 22 de desembre de 1491; ibid., any 1492, s/f, 21 de maig de 1492, 10 de setembre de 1492 .

\section{Bibliografia}

SANCHIS Y SIVERA (1909): 457, nota 1.

\section{Honorat Strimundi [Estramundi, Estramudi, Extramundi]}

Cantor - Mestre de cant / Catedral de València

Procedent possiblement de la diòcesi d'Amelia als Estats Pontificis, ja era prevere cantor a la seu de València a la darreria del 1482, gaudint d'un salari de dos senyals. Com que no era beneficiat, dos anys després la diòcesi valenciana li va atorgar llicència per a substituir el titular d'un benefici a la parròquia de Sant Joan de Jerusalem. És possible que temporalment es fera càrrec dels fadrins diputats al voltant del 1489. El 1496 estava absent de la catedral i li varen ser retirats els seus senyals; però només dos mesos més tard ja havia tornat i el seu salari fou restituït. En morir Guillem de Podio, va substituir-lo en el magisteri de cant. Va rebre el primer nomenament anual en aquest càrrec el 26 d'abril de $1501 \mathrm{i}$, probablement, va exercir-lo fins la seua mort, que es va produir entre el 27 d'agost i el 16 de setembre de 1504 . Des del 1501 la catedral va subvencionar freqüentment les despeses causades per la seua malaltia. Posseïa llibres de cant, que va llegar a la seu. A més, disposava de més de cinquanta llibres manuscrits i d'impremta sobre teologia, literatura, filosofia i altres assumptes, entre els quals hi havia un imprès titulat Opera Divi Boetii.

\section{Documents}

- 16 de desembre de 1484. És prevere de diòcesi no valenciana -podria ser de la diòcesi italiana d'Amelia (lectura dubtosa)- i obté llicència per a ser substitut en un benefici a la parròquia de Sant Joan de Jerusalem de València, ja que no té cap en propietat [ADV, Col-lacions de beneficis, vol. 141/002, f. 205r].

- Any administratiu de 1489. És xantre de la seu de València i li paguen 30 sous per les despeses fetes en un diputat malalt de pesta $[E-V A c$, Almoina, Procura major, vol. 5685, f. $34 \mathrm{v}]$.
- 26 d'agost de 1491. És restituït el senyal que tenia de salari a la seu de València [E-VAc, not. Jaume Esteve, vol. 3685, $\mathrm{s} / \mathrm{f}]$.

- 28 de març de 1496. És absent de València i el capítol de la seu de València ordena que els seus dos senyals es prorrategen entre els cantors Jaume Martí i Garcia Salelles [E-VAc, not. Jaume Esteve, vol. 3687, s/f].

- 9 de maig de 1496. El capítol de València ordena que li donen dos senyals que tenien dos antics diputats $[E-V A c$, not. Jaume Esteve, vol. 3687, s/f].

- 26 d'abril de 1501. És nomenat substitut del canonge rector de les escoles del cant (mestre de cant) de la seu de València [E-VAc, not. Joan Esteve, vol. 3596, f. 102r-103v].

- $26 \mathrm{~d}$ 'abril de 1503 . És nomenat substitut del canonge rector de les escoles del cant (mestre de cant) de la seu de València [E-VAc, not. Jaume Esteve, vol. 3605, f. 219v-221v].

- $26 \mathrm{~d}$ 'abril de 1504. És nomenat substitut del canonge rector de les escoles del cant (mestre de cant) de la seu de València [E-VAc, not. Jaume Esteve, vol. 3605, f. 188r-189r].

- 27 d'agost de 1504. Darrer testament d'Honorat Strimundi, xantre de la seu de València. Publicat el 16 de setembre de 1504 [E-VAcp, not. Felip de Abella, vol. 677, s/f].

- 19 i 24 de setembre de 1504. Inventari post mortem dels seus béns [E-VAcp, not. Felip de Abella, vol. 677, $\mathrm{s} / \mathrm{f}]$.

- 24 i 25 de setembre, 7 i 12 d'octubre de 1504 . Encant dels seus béns [E-VAcp, not. Felip de Abella, vol. 677, $\mathrm{s} / \mathrm{f}]$.

- Cobraments: E-VAc, Almoina, Procura Major, vol. 5658, any 1482 , f. 32r; ibid., vol. 5685, any 1483 , f. 34 v; ibid., any 1484 , f. 33v; ibid., any 1485 , f. 33v; ibid., any 1486 , f. $33 \mathrm{v}$; ibid., any 1487 , f. $31 \mathrm{v}$; ibid., vol. 5658, any 1488 , f. 32v; ibid., vol. 5685, any 1489, f. 31v; ibid., vol. 5686, any 1491 ,f. $31 \mathrm{v}, 32 \mathrm{v}$; ibid., any 1492 , f. $18 \mathrm{r}, 52 \mathrm{v}$; ibid., any 1493, f. 43v, 44r; ibid., vol. 5687, any 1501, f. 42r; ibid., any 1502 , f. 39r; ibid., any 1503 , f. 42v, 44r, 44v, 45r, 46r, $46 \mathrm{v}, 48 \mathrm{v}$; ibid., any 1504 , f. 41 r. $E-V A c$, not. Joan Esteve, vol. 3683, any 1483, s/f, 20 de març de 1483, 8 d'agost de 1483, 17 de desembre de 1483; ibid., any 1484, s/f, 11 de setembre de 1484, 12 d'abril de 1484; ibid., any 1485, s/f, 27 de gener de 1485, 23 de junio de 1485, 5 de novembre de 1485. E-VAc, not. Jaume Esteve, vol. 3685, any 1487 , s/f, 13 de gener de 1487, 1 de juny de 1487, 14 de setembre de 1487, 17 de novembre de 1487; ibid., any 1488, s/f, 13 de maig de 1488, 10 d'octubre de 1488; ibid., any 1489, s/f, 10 de gener de 1489, 16 d'abril de 1489; ibid., vol. 3686, any 1492, s/f, 21 de març de 1492, 27 d'agost de 1492; ibid., any 1493, s/f, 23 de febrer de 1493, 7 de setembre de 1493, 21 d'agost de 1493. 


\section{Juan de Tovar}

Cantor - Mestre de capella / Catedral de València

La primera notícia d'aquest músic data del 1490, quan era prevere i mestre de cant resident a la ciutat de Saragossa. El 30 d'octubre de 1500 va incorporar-se com a cantor a la seu de València amb salari de dos senyals. No va exercir l'ofici massa temps, ja que el 29 de desembre se n'havia anat. Vint anys després va tornar a la mateixa seu, encara que com a mestre de capella. Amb aquest motiu, a mitjan 1520 rebia un senyal, però també va marxar prompte. El 2 de juliol de 1521 ja no hi era a la seu valenciana. Es desconeix si tenia algun lligam familiar amb el teòric Francisco Tovar, mestre capella de la seu de Tarragona i autor d'un Libro de música práctica, publicat a Barcelona el 1510 .

\section{Documents}

- 30 d'octubre de 1500. Li són adjudicats dos senyals a la seu de València per absència del xantre Jaume Just [E-VAc, not. Lluís Esteve, vol. 3631, s/f, fora d'enquadernació].

- 29 de desembre de 1500 . Ha marxat de la seu de València, per la qual cosa són vacants els seus senyals $[E-V A c$, not. Lluís Esteve, vol. 3631, s/f, fora d'enquadernació].

- 26 de juny de 1520 . Li és assignat un senyal com a mestre de capella de la seu de València [E-VAc, Almoina, Pagador dels senyals, vol. 5614, any 1519, s/f].

- 2 de juliol de 1521. Per absència de Tovar, el capítol de la seu de València adjudica el seu senyal al cantor Jeroni Ballester [E-VAc, Almoina, Pagador dels senyals, vol. 5614 , any $1521, \mathrm{~s} / \mathrm{f}]$.

Bibliografia

PALLARÉS JIMÉNEZ, 15:1-2 (Saragossa, 1999): 471.

Joan Trocera $\rightarrow$ Joan Trossera àlies Martínez

\section{Joan Trossera [Trocera] àlies Martínez}

Organista / Catedral de València

D'origen probablement valencià, ja era prevere beneficiat de la seu de València uns anys abans de ser nomenat organista, on ocupava algun càrrec administratiu. En aquest temps, va invertir els seus diners en el negoci tèxtil del seu germà Pasqual Trossera, que era calceter. En un testament de 1489, que no va ser el darrer, es declarava membre de la confraria de Sant Jaume i delatava l'existència d'un altre germà anomenat Domènec Trossera, pare d'un nebot del mateix nom al qual nomenava el seu hereu. Vivia amb una dona anomenada Caterina a la que feia usufructuària dels seus béns. És possible que es tractara de la vídua Caterina Luçot, la qual designaria Trossera com a hereu tres anys després. El 4 de febrer de 1491 era nomenat organista de la seu, amb el mateix salari que tenia el seu predecessor. Des de mitjan 1492 va compartir el càrrec, i les retribucions, amb
Pere Castell. No obstant això, aconseguiren un augment de 5 lliures per a cadascú. A la darreria d'aquest any va redactar un codicil amb la intenció que, després de mort, se celebrara un aniversari a l'església de Sant Martí, d'on possiblement fóra parroquià. De fet, el 1500 comprava una casa en aquest mateix àmbit parroquial. Sense incidències destacables, va exercir l'ofici de forma compartida amb Castell fins l'arribada de Pere Vila a mitjan 1510.

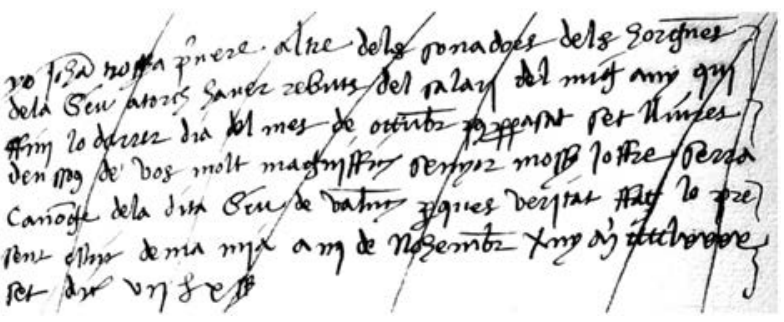

Manuscrit autògraf de Joan Trossera

[E-VAc, Tresoreria, vol. 1291, any 1497, s/f]

\section{Documents}

- Any administratiu de 1486. És distribuïdor dels senyals de l'Almoina de la seu [E-VAc, Almoina, Procura major, vol. 5685 , any 1486 , f. 32v].

- 25 d'agost de 1487. És prevere beneficiat a la seu de València quan compra un censal de 25 sous [E-VAcp, not. Joan Pla, vol. 15559, s/f].

- 19 de novembre de 1489. Fa societat amb el seu germà Pasqual Trossera, calceter, per a vendre draps de llana i de cordellat, fer sandàlies i altres treballs de l'ofici de calceter, per la qual cosa aporta un capital de 50 lliures [E-VAcp, not. Bartomeu de Carries, vol. 20450, s/f].

- 19 de novembre de 1489. Testament de Joan Trossera [E-VAcp, not. Joan Pla, vol. 15561, s/f].

- 4 de febrer de 1491. És nomenat pel capítol en l'ofici d'organista per mort d'Onofre Ferrer amb el sou acostumat [E-VAc, not. Jaume Esteve, vol. 3686, s/f].

- 22 d'agost de 1492. Rep un augment de sou de 5 lliures, al mateix temps que Pere Castell [E-VAc, not. Jaume Esteve, vol. $3605, \mathrm{~s} / \mathrm{f}]$.

- 17 de desembre de 1492. És nomenat hereu de Caterina Luçot, vídua d'Antoni Luçot, mercader [E-VAcp, not. Joan Pla, vol. 15563, s/f].

- 16 de setembre de 1494. Codicil de Joan Trossera [E-VAcp, not. Joan Pla, vol. 15569, s/f].

- 20 de gener de 1500. Compra una casa al carrer de la confraria dels Tapiners a la parròquia de Sant Martí per 60 lliures [E-VAcp, not. Joan de Arbequa, vol. 20598, s/f]. - Cobraments (exhaustiu només en el període d'estudi): E-VAc, Tresoreria, vol. 1291, any 1494, s/f; ibid., any 1497, 
s/f; ibid., any 1498, s/f; ibid., vol. 1292, any 1505, s/f; ibid., any 1506, s/f; ibid., any 1508, s/f; ibid., any 1509, s/f; ibid., any 1510 , s/f. $E-V A c$, Fàbrica, vol. 1485, any 1491, f. 18r, 18v. E-VAc, not. Jaume Esteve, vol. 3686, any 1491, s/f, 30 d'abril 1491, 10 de novembre de 1491; ibid., any 1492, s/f, 3 d'abril de 1492, 28 d'abril de 1492, 14 de desembre de 1492; ibid., vol. 3687, any 1494, s/f, 27 d'octubre de 1494; ibid., any 1496, s/f, 6 d'abril de 1496; ibid., any 1497, s/f, 13 d'abril de 1497; ibid., any 1498, s/f, 28 d'abril de 1498, 12 de novembre de 1498; ibid., vol. 3688, any 1500, s/f, 19 de març de 1500; ibid., any 1502, s/f, 18 d'abril de 1502; ibid., any 1503, s/f, 21 d'abril de 1503; ibid., vol. 3689, any 1507 , s/f, 19 d'abril de 1507. E-VAc, not. Felip Abella, vol. 3698 , any 1508 , f. $97 \mathrm{v}, 25$ de setembre de 1508; ibid., any 1509, f. 115r, 4 d'abril de 1509; ibid., any 1510, f. 212r, 8 d'agost de 1510; ibid., f. 197r.

Bibliografia

VILLANUEVA SERRANO, 64 (Barcelona, 2009): p. 94; (2011): 54 .

\section{Joan (de) Vera}

Cabiscol / Catedral de València

Va nàixer a Alzira el 26 de desembre de 1453. El 1477 era batxiller en dret i ja gaudia d'un benefici eclesiàstic a València que va permutar per altre a Alzira. El 1484 s'havia doctorat en dret i era vicari general del bisbe de Sogorb i tres anys més tard posseïa la rectoria de Carlet. El 1490 va prendre un canonicat a la seu de València. Sota la protecció del papa Alexandre VI, el qual l'havia fet preceptor del seu fill Cèsar, va acumular diversos càrrecs rellevants en aquesta seu. El 1494 havia obtingut la dignitat de la cabiscolia, l'any següent era vicari general de la diòcesi i el 1496 era protonotari apostòlic de la diòcesi, de manera que es convertí en el membre més poderós del capítol. Fou sotmès a un procés per una suposada conducta escandalosa que va concloure l'any 1498 sense conseqüències. En aquest temps va rebre la dedicatòria per part de Guillem de Podio, mestre de cant de la seu valenciana, de l'Enchiridion de principiis musice. Atès que tenia la intenció d'anar a Roma, va atorgar el seu darrer testament el 20 d'abril de 1500 , en què nomenà hereu al seu germà Garcia de Vera. A mitjan 1500 es va traslladar a la cort romana i en algun moment d'aquest any, posterior a la data del testament, va renunciar a la dignitat de cabiscol de València, que va prendre Sanç de Vera. Al cap de pocs mesos, Joan de Vera va obtenir el nomenament d'arquebisbe de Salern i el de cardenal. A mitjan 1503, després de la mort d'Alexandre VI, va haver-hi un intent de Cèsar Borja d'elevar-lo al papat que no prosperà. Des del mateix any, Vera va rebre diverses prebendes a Burgos, Lleida i Saragossa, i el bisbat de Lleó, del qual no arribà a prendre possessió. Del 1504 al 1505 fou camarleng del col-egi cardenalici. Va morir a Roma el 4 de maig de 1507.

\section{Documents}

- 30 d'agost de 1477 és batxiller en dret d'Alzira quan permuta el seu benefici a l'església de Sant Joan de Jerusalem de València per un altre en la parròquia de Santa Caterina d'Alzira [ADV, Col·lacions de beneficis, vol. 140/002, f. 180r].

- 20 de maig de 1484. És doctor en decrets i vicari general del bisbe de Sogorb quan és nomenat marmessor de Guillem Vich, cabiscol de la seu de València [E-VAcp, not. Bartomeu Bodí, vol. 14401, s/f].

- 22 de febrer de 1487. És doctor en decrets i rector de la parròquia del lloc de Carlet $[E-V A c$, not. Jaume Esteve, vol. 3689 , s/f].

- 23 de juliol de 1490. Pren possessió d'una canongia a la seu de València [E-VAc, not. Joan Esteve, vol. 3596. f. 2r; ibid., not. Jaume Esteve, vol. 3685, s/f].

- 27 de setembre de 1494. És canonge i cabiscol de la seu de València [E-VAc, not. Jaume Esteve, vol. 3687, s/f].

- 17 d'agost de 1495. És vicari general de l'arquebisbe de València [E-VAc, not. Jaume Esteve, vol. 3687, s/f].

- 28 de setembre de 1496. És protonotari apostòlic de la seu de València [E-VAc, not. Jaume Esteve, 27 d'abril de 1498. És vicari general de València [E-VAc, not. Joan Esteve, vol. 3596, f. 132r-132v, 139r].

- 23 de març de 1500. És cabiscol de la seu de València [E-VAc, not. Joan Esteve, vol. 3688, s/f].

- 20 d'abril de 1500. Darrer testament de Joan de Vera, doctor en decrets, canonge i cabiscol de la seu de València [E-VAar, not. Joan Comes, vol. 603, s/f].

- Any 1500. Sanç de Vera és nomenat cabiscol de la seu de València [E-VAc, Pahoner, 13, vol. 389, f. 433r].

- 28 de setembre de 1500. És creat cardenal per Alexandre VI [E-VAc, not. Jaume Esteve, vol. 3688, s/f].

- 13 d'abril de 1502. Ha renunciat a la seua dignitat de cabiscol de la seu de València $[E-V A c$, not. Joan Esteve, vol. 3596, f. 151r, 14 de desembre de 1502].

Bibliografia

GOÑI (1973): vol. IV, 2732-2733. HINOJOSA MONTALVO (2004): vol. 4, 358-359.

\section{Sanç de Vera}

Cabiscol / Catedral de València

Va prendre la dignitat de cabiscol de la seu de València el 1500, després de la renúncia de Joan de Vera, la qual cosa suggereix que tenien relació familiar. El 1504 encara gaudia de la cabiscolia i era canonge el 1522. Va rebre nombrosos beneficis, especialment a Alzira. Encara vivia el 1522 . 


\section{Documents}

- Any 1500. Sanç de Vera és nomenat cabiscol de la seu de València [E-VAc, Pahoner, 13, vol. 389, f. 433r].

Bibliografia

GOÑI (1973): vol. IV, 2732-2733. PONS ALÓS i CÁRCEL

ORTÍ, 35:2 (Barcelona, 2005): 949-950. HINOJOSA MONTALVO (2004): vol. 4, 358-359.

\section{Andreu Vicent}

Cantor/ Catedral de València

Era frare i va exercir l'ofici de cantor a la seu de València, encara que es desconeix durant quant de temps. Només se sap que el 1495 el capítol va atorgar-li una subvenció per al seu retir. Amb tota seguretat ja no era cantor el 1511, puix no apareix tampoc en els llibres de comptes del pagador dels senyals de l'Almoina que es conserven d'aquest any.

Document

- 3 de juliol de 1495. El capítol determina que li paguen 2 ducats per subvenció al seu retir [E-VAc, not. Jaume Esteve, vol. 3605, fora d'enquadernació].

\section{Guillem de Vich}

Cabiscol / Catedral de València

Era canonge de la seu de València el 1442 i el 1461 ja havia obtingut la dignitat de cabiscol. Era doctor en dret i va actuar com a vicari general del bisbe. Va mantenir la cabiscolia fins un mes abans de la seua mort, ocorreguda l'1 de febrer de 1485, quan va renunciar perquè prenguera possessió el seu probable familiar Guillem Ramon Vich. Va nomenar hereu el bisbe de Sogorb.

\section{Documents}

- 1461. És cabiscol de la seu de València [E-VAc, Càmbra apostòlica, vol. 4478, s/f].

- 20 de maig de 1484. Darrer testament de Guillem de Vich, doctor en decrets, canonge i cabiscol de la seu de València, i rector de la parròquia de Carlet $[E-V A c p$, not. Bartomeu Bodí, vol. 14401, 20 de maig de 1484].

- 5 de gener de 1485. Renuncia a la dignitat de cabiscol de la seu de València [E-VAc, not. Joan Esteve, vol. 3683, 7 de gener de 1485].

Bibliografia

PONS ALÓS i CÁRCEL ORTÍ, 35:2 (Barcelona, 2005): 950.

\section{Guillem Ramon de Vich}

Cabiscol / Catedral de València

Era fill de Lluís Vich, mestre racional del Regne de València, i de Damiata de Vallterra. Va rebre un canonicat i la cabiscolia de la seu de València el 7 de gener de 1485 , però sembla que només va gaudir d'aquesta darrera dignitat un mes, ja que el 2 de febrer prenia possessió Martí Enyego de la mateixa plaça. Com molts altres nobles valencians de l'època, va passar a Itàlia. El 1492 es trobava a Florència cursant estudis jurídics. Va ser creat cardenal el 1517, l'any següent va rebre el bisbat de Cefalú a Sicília i en el període 1519-1521 fou bisbe coadjutor de Barcelona, sense residir en aquesta ciutat. Va morir el 1525 a l'abadia de Casamari a la diòcesi de Veroli i va ser soterrat a la basílica de la Santa Creu de Jerusalem a Roma.

Documents

- 7 de gener de 1485. Pren possessió d'un canonicat i la dignitat de cabiscol de la seu de València $[E-V A c$, not. Joan Esteve, vol. 3683, any 1485, s/f].

Bibliografia

PONS ALÓS i CÁRCEL ORTÍ, 35:2 (Barcelona, 2005): 950.

Antoni Ximénez $\rightarrow$ Antoni Eximénez

Antoni Ximeno $\rightarrow$ Antoni Eximénez

\section{BIBLIOGRAFIA}

Aguilera Cerni, Vicente, Història de l'Art Valencià. València, Consorci d'editors valencians, 1986-1987, vol. 2-3.

Álvarez Pérez, José María, "La Polifonía Sagrada y sus maestros en la Catedral de León durante el siglo XVII", Anuario Musical, 14 (Barcelona, 1959): 39-62.

Andrés Ferrandis, Antonio, La música en los códices, incunables y raros de la catedral de València. València, Institució Alfons el Magnànim, 2001, Compendium Musicae, 1.

Anglés, Higinio, "La notación musical española de la segunda mitad del siglo XV. Un tratado desconocido de Guillermus... de Podio", Anuario Musical, 2 (Barcelona, 1947): 151-173.

Anglés, Higinio (ed.), La Música en la Corte de los Reyes Católicos, Cancionero Musical de Palacio (siglos XVXVI). Barcelona, CSIC, 1951, 2 vol

Anglés, Higinio, "La música en la Corte Real de Aragón y de Nápoles durante el reinado de Alfonso V el Magnánimo", José López-Calo (ed.), Hygini Anglés, Scripta Musicologica II, Roma, Edizioni di Storia e Letteratura, 1975a: 963-1028 [1a edició: Cuadernos de trabajos de la Escuela Española de Historia y Arqueología en Roma, IX (Roma, 1961): 81-142].

Anglés, Higinio, "Spanien in der Musikgeschichte des 15. Jahrhunderts", José López-Calo (ed.), Hygini Anglés, Scripta Musicologica II, Roma, Edizioni di Storia e Letteratura, 1975b: 869-911 [1 a edició: Festschrift für 
Johannes Vincke zum 11. Mai 1962, Madrid, CSIC, 1962-1963: 321-356].

Atlas, Allan W., Music at the aragonese court of Naples. Cambridge, Cambridge University Press, 1985.

Calahorra Martínez, Pedro, La Música en Zaragoza en los siglos XVI y XVII. Polifonistas y ministriles. Zaragoza, Institución "Fernando el Católico", 1978, vol. 2.

Calahorra Martínez, Pedro (ed.): Autores hispanos de los siglos XV-XVI de los ms. 2 y 5 de la catedral de Tarazona. Zaragoza, Institución «Fernando el Católico», Diputación de Zaragoza, 1995.

Cañas Gálvez, Francisco de Paula, "La música en la corte de Enrique IV de Castilla (1454-1474). Una aproximación institucional y prosopográfica”, Revista de Musicología, 29:1 (Madrid, 2006): 217-313.

Cañas Gálvez, Francisco de Paula, "La evolución política en Castilla durante el siglo XV: de Juan II a los Reyes Católicos. Perspectiva bibliográfica de la nueva historia política y sus aplicaciones metodológicas", eHumanista, 10 (Santa Bárbara, 2008): 31-50.

Cárcel Ortí, Vicente, Historia de las tres diócesis valencianas. València, Generalitat Valenciana, 2001.

Ciprés de Pobar, Silvio, Origen y progresso de las pabordrías de la Sancta e Metropolitana Iglesia de Valencia. Roma, Emprenta de la rever. Cámara Apostólica, 1641.

Civil Castellví, Francisco, "Personajes y aconteceres musicales", Revista de Girona, 58 (Girona, 1er trimestre 1972): 59-64.

Climent Barber, Josep, "El órgano de la Catedral de Valencia en 1483", Revista de Musicología, X:1 (Madrid, 1987): 163-169.

Dalmases Balañá, Núria de, Orfebreria catalana medieval. Barcelona 1300-1500. Barcelona, Institut d'Estudis Catalans, 1992, vol. 2.

Ferrer Gimeno, María Rosario, "La Biblioteca del Canónigo Maties Mercader (+1489)", Estudis Castellonencs, 4 (1987-1988): 441-469.

Fétis, François Joseph, Biographie universelle des musiciens et bibliographie generale de la musique. París, FirminDidot et Cie, 1878, vol. VII.

Fita, Fidel, "Los reys de Aragó y la séu de Girona desde l'any 1462 fins al 1482", La Renaixensa (Barcelona, 1871-1873).

Fita, Fidel, Los reys de Aragó y la séu de Girona desde l'any 1462 fins al 1482. Sèrie segona. Barcelona, Imprenta de la Renaixensa, 1876.

Gerber, Rudolf (ed.), Spanisches Hymnar um 1500. Wolfenbüttel, Möseler Verlag, 1957.

Goñi, J., "Vera, Juan”, Quintín Aldea Vaquero, Tomás Marín Martínez i José Vives Gatell (ed.), Diccionario de
Historia Eclesiástica de España, Madrid, Instituto Enrique Florez, CSIC, 1973, vol. IV: 2732-2733.

Gregori i Cifré, Josep Maria, "Mateu Ferrer, tenorista i mestre de cant de la Seu de Barcelona (1477-1498)", Recerca Musicològica, III (Barcelona, 1983): 7-37.

Gregori i Cifré, Josep Maria, "Pere Alberch artífex de la relació musical entre les Seus de Girona i Barcelona en el Renaixement tardà", Annals de l'Institut d'Estudis Gironins, 28 (Girona, 1985-1986): 281-298.

Hinojosa Montalvo, José, Diccionario de Historia Medieval del Reino de Valencia. València, Biblioteca Valenciana, 2002, 4 vol.

Knighton, Tess, Música y músicos en la corte de Fernando el Católico, trad. per Luis Gago. Saragossa, Institución "Fernando el Católico", Sección de Música Antigua, Excma. Diputación de Zaragoza, 2001a.

Knighton, Tess, "Rodríguez de la Torre, Juan [Juan de Sanabria, Juan de Senabria, Rodríguez de Sanabria]", Emilio Casares Rodicio (ed.), Diccionario de la Música Española e Hispanoamericana, Madrid, Sociedad General de Autores y Editores, 2001b, vol. 7: 893.

López-Calo, José, La música en la catedral de Burgos, vol. III, Documentario Musical, Actas Capitulares (I). Burgos, Caja de ahorros del Círculo Católico, 1996.

López Martínez, Nicolás, "Don Luis de Acuña, el cabildo de Burgos y la reforma (1456-1495)", Burgense, 2 (Burgos, 1961): 185-317.

Madurell, José $\mathrm{M}^{\mathrm{a}}$, "Documentos para la Historia de los Maestros de capilla, cantores, organistas, órganos y organeros. Siglos XIV-XVIII", Anuario musical, 6 (Barcelona, 1951): 205-225.

Mas, Josep, "Nota històrica. Taula dels Mestres del Cant, o de Capella, de la Seu de Barcelona", El Correo Catalán (Barcelona, 25 de desembre de 1917): 1-2.

Melchor Fenollosa, Roser, Maties Mercader. Pràtica de citreria (1475): Edició crítica. Introducció i notes, tesi doctoral. València, Universitat de València, 2014.

Miglio, Massimo, Anna Maria Oliva i Carmen Pérez García (ed.), Rinascimento italiano e commitenza valenzana. Gli Angeli musicanti della cattedrale di València. Roma, Istituto storico italiano per il medio evo, 2011.

Moll Roqueta, Jaime, "El estatuto de maestro cantor de la catedral de Ávila del año 1487", Anuario Musical, 22 (Barcelona, 1967): 89-95.

Mujal Elías, Juan; Lérida. Historia de la Música. Lleida, Dilagro, 1975.

Munsuri Rosado, $\mathrm{M}^{\mathrm{a}}$ Nieves, El clero secular en la Valencia del siglo XV. València, Del Senia al Segura, 2010. 
Nicolau Bauzà, P. Josep, ”Un orgue per a la Parròquia de Sant Tomàs de València (1489)", Cabanilles, 17 (València, gener-març de 1986): 12-15, 27-30.

Pallarés Jiménez, Miguel Ángel, “Aportación documental para la historia de la música en Aragón en el último tercio del siglo XV. IV", Nassarre, 8:2 (Saragossa, 1992): 171-244.

Pallarés Jiménez, Miguel Ángel, “Aportación documental para la historia de la música en Aragón en el último tercio del siglo XV. VI", Nassarre, 15:1-2 (Saragossa, 1999): 419-513.

Pedrell, Felipe, Diccionario biográfico y bibliográfico de músicos y escritores de música españoles, portugueses é hispano-americanos antiguos y modernos: acopio de datos y documentos para servir á la historia del arte musical en nuestra nación. Barcelona, Víctor Berdós y Feliu, 1897.

Pérez de Miedes, Miquel, Constitutiones sive ordinationes insignis metropolitanae ecclesiae valentinae. València, Ioannes Mey, 1546.

Pons Alós, Vicente i María Milagros Cárcel Ortí, "Los canónigos de la Catedral de Valencia (1375-1520). Aproximación a su prosopografía”, Anuario de Estudios Medievales, 35:2 (Barcelona, 2005): 907950.

Prats Redondo, Consuelo, Música y músicos en la catedral de Murcia. Entre 1600-1750, tesi doctoral. Múrcia, Universidad de Murcia, 2009.

Real Academia de la Historia, Cortes de los antiguos reinos de Aragón y de Valencia y Principado de Cataluña, Cortes de Cataluña. Madrid, Real Academia de la Historia, 1904-1922, 26 vol.

Riquer, Martí de, Història de la literatura catalana. Barcelona, Ariel, 1980, 1a edició 1964, vol. 2.

Ruiz Jiménez, Juan, “'The sounds of the hollow mountain': musical tradition and innovation in Seville cathedral in the early Renaissance", Early Music History, 29 (Cambridge, 2010): 189-239.

Ruiz de Lihory, José, La Música en Valencia. Diccionario biográfico y crítico. València, Establecimiento tipográfico Doménech, 1903.

Rubio, Samuel, Desde el "ars nova" hasta 1600. Historia de la música española, 2. Madrid, Alianza Editorial, 1983.

Sanchis y Sivera, José, La Catedral de Valencia. Guía Histórica y Artística. València, Imprenta de Francisco Vives Mora, 1909.
Sanchis y Sivera, José, "Organeros medievales en Valencia", Boletín de la Real Academia de la Historia, 86 (Madrid, abril-juny, 1925): 467-473.

Sherr, Richard, "The 'Spanish Nation' in the Papal Chapel, 1492-1521", Early Music, 20:4, Iberian Discoveries I (Oxford, novembre de 1992): 601-609.

Sierra, Sylvie, La vie musicale a la cathedrale de Valencia au XVème siécle, tesi. París, Université Paris-Sorbonne, 1985.

Stevenson, Robert, La Música en la Catedral de Sevilla, 1478-1606. Documentos para su estudio. Madrid, Sociedad Española de Musicología, 1985.

Teixidor, Josef, Antigüedades de Valencia. València, Imprenta de Francisco Vives Mora, 1895, vol. II.

Villalmanzo, Jesús, "Pere Castell, organista de la Seu de Valencia (14---1514)", Cabanilles, 12 (València, octubre-desembre 1984): 14-21, 24-28.

Villanueva Serrano, Francesc, "Mateo Flecha en la catedral de Valencia: sus dos períodos de magisterio de capilla y su entorno musical", Anuario Musical, 64 (Barcelona, 2009): 57-108.

Villanueva Serrano, Francesc, "El tractadista Guillermus de Podio: bases per a la construcció d'una biografia", Anuario musical, 65 (Barcelona, 2010): 3-23.

Villanueva Serrano, Francesc, "La identificación de Pedro de Escobar con Pedro do Porto: una revisión definitiva a la luz de nuevos datos", Revista de Musicología, 34:1 (Madrid, 2011): 37-58.

Villanueva Serrano, Francesc, "Los órganos de la catedral de Valencia en el tránsito del Gótico al Renacimiento", Nassarre, 30 (Saragossa, 2014a): 15-68.

Villanueva Serrano, Francesc, "The great organ of Valencia Cathedral, 1460-1471. A lost instrument", The Organ Yearbook, 43 (Laaber, 2014b): 7-31.

Villanueva Serrano, Francesc, Guillem de Podio $(* 1420 c$; $\dagger 1500)$ : estudi biogràfic crític, entorn musical a la cort de Joan II d'Aragó i l'obra Enchiridion de principiis musice discipline contra negantes illa et destruentes, tesi doctoral. València, Universitat Politècnica de València, 2015.

Villanueva Serrano, Francesc, A la honor e mostrar stado. La música en la corte de Juan II de Aragón. Madrid, Sociedad Española de Musicología, 2016.

Vones-Liebenstein, Ursula, "El método prosopográfico como punto de partida de la historiografia eclesiástica", Anuario de Historia de la Iglesia, 14 (Pamplona, 2005): 351-364.
Recibido: 28.04 .2017

Aceptado: 17.07.2017 